AUTARQUIA ASSOCIADA À UNIVERSIDADE DE SÃO PAULO

\title{
CARACTERIZAÇÃO DO CROMO PRESENTE NO LODO DE GALVANOPLASTIA: AVALIAÇÃO TÉCNICA E ECONÔMICA DE PROCESSOS DE REMOÇÃO
}

\author{
LUCAS CAMPANER ALVES
}

Dissertação apresentada como parte dos requisitos para obtenção do Grau de Mestre em Ciências na Área de Tecnologia Nuclear - Materiais

Orientadora:

Profa. Dra. Emília Satoshi Miyamaru Seo 


\section{INSTITUTO DE PESQUISAS ENERGÉTICAS E NUCLEARES}

Autarquia associada à Universidade de São Paulo

\section{CARACTERIZAÇÃO DO CROMO PRESENTE NO LODO DE GALVANOPLASTIA: AVALIAÇÃO TÉCNICA E ECONÔMICA DE PROCESSOS DE REMOÇÃO}

\section{LUCAS CAMPANER ALVES}

Dissertação apresentada como parte dos
requisitos para obtenção do Grau de
Mestre em Ciências na Área
de Tecnologia Nuclear-Materiais

Orientadora:

Profa. Dra. Emília Satoshi Miyamaru Seo

Versão Corrigida

Versão Original disponível no IPEN

São Paulo

2016 


\section{AGRADECIMENTOS}

Agradeço, primeiramente, a Deus por sua abundante graça e ajuda durante o desafio que este curso de mestrado representou para mim nestes últimos anos.

A minha mãe Josilene, ao meu pai Alexandre, aminha avó Guerina e meu avô Albino, meu irmão Jonas, ao meu amigo Luís, a minha namorada Suelem e toda minha família e aos amigos pelo amor, ajuda, dedicação, estimulo, investimento e paciência.

Agradeço em especial a minha tia Josimara pelas correções e sugestões ortográficas apresentadas na elaboração desta dissertação.

Ao Instituto de Pesquisas Energéticas e Nucleares - IPEN por oferecer as condições necessárias para realizar esta dissertação.

A Dra. Emília Satoshi Miyamaru Seo pela orientação, apoio, crescimento e amizade durante os anos como aluno de estagio voluntário e mestrado.

Ao Marco Andreoli pela experiência, discussão, contribuição e amizade durante os anos convividos no CCTM.

A Dra. Maricel, o Dr. Oscar Vega e a todo ao Centro de Química e Meio Ambiente (CQMA) pelas análises de ICP-OES e Absorção Gasosa.

Ao Dr. Martinelli e a Dra. Marlene pelas análises de fluorescência de raios x por energia dispersiva.

Agradeço as pessoas que conheci e convivi durante esse período pela amizade e companheirismo. 


\title{
CARACTERIZAÇÃO DO CROMO PRESENTE NO LODO DE GALVANOPLASTIA: AVALIAÇÃO TÉCNICA E ECONÔMICA DE PROCESSOS DE REMOÇÃO
}

\author{
Lucas Campaner Alves
}

\section{RESUMO}

O lodo gerado em processos de galvanoplastia é classificado pela ABNT NBR 10.004/04 como perigoso (classe I). Na literatura encontram-se poucos estudos referentes à recuperação do cromo presente no lodo gerado em sistemas de tratamento de efluentes de indústrias de galvanoplastia. Neste sentido, o presente estudo avaliou a remoção do cromo presente no lodo de galvanoplastia por meio de dois processos, visando avaliar à eficiência técnica e a viabilidade econômica de ambos. O Processo 1 consistiu na remoção do cálcio utilizando o ácido cítrico, seguida de lixiviação ácida. Na etapa de oxidação, variou-se a temperatura em $40^{\circ} \mathrm{C}, 60^{\circ} \mathrm{C}$ e $80^{\circ} \mathrm{C}$ e no tempo de 30,60 e 90 minutos, tendo em vista que a eficiência do processo de oxidação depende da temperatura e tempo. Nesta etapa do processo as concentrações de peroxido de hidrogênio $\left(\mathrm{H}_{2} \mathrm{O}_{2}\right)$ utilizadas foram de 1,50, 3,00 e 4,50 mol..-1 . O Processo 2 realizou a oxidação do cromo sem efetuar as etapas de extração do cálcio e a lixiviação ácida. A oxidação do cromo ocorreu pelo mesmo método apresentado no Processo 1. A caracterização elementar da amostra determinou que o principal elemento constituinte do lodo é o cálcio (20,05\% em massa), e que dentre os metais pesados destacam-se o cromo e o níquel $(6,52 \%$ e $4,33 \%$ em massa, respectivamente). A maior eficiência de remoção do cálcio foi obtida na razão mássica de 8,00 (ácido cítrico/hidróxido de cálcio), com 51,76\% em massa, seguida pela razão mássica de 5,50 com $36,75 \%$ em massa e 2,50 com 24,83\% em massa. O melhor resultado de oxidação do cromo no Processo 1 foi obtido com tempo de 30 minutos, temperatura de $60^{\circ} \mathrm{C}$ e concentração de peroxido de hidrogênio de 3,00 mol.L-1 , com eficiência de 41,09\% em massa. No Processo 2, obteve-se a remoção de $37,96 \%$ em massa de cromo a temperatura de $80^{\circ} \mathrm{C}$, por uma hora e 3,00 mol.L-1 de peróxido de hidrogênio. Avaliando os custos para 
remoção do cromo dos dois processos, determinou-se que o Processo 1 foi mais oneroso que 02 , porém ambos não apresentaram viabilidade econômica para aplicação em escala industrial. Nos dois processos efetuou-se a oxidação do cromo presente no lodo de galvanoplastia, permitindo a sua remoção parcial neste resíduo. Com isso obtiveram-se ganhos ambientais, pela diminuição deste elemento no resíduo de galvanoplastia, que na maioria das vezes é disposto em aterros classe I, gerando um passivo ambiental. 


\title{
CHARACTERISTICS OF CHROMIUM FROM ELECTROPLATING SLUDGE: TECHNICAL AND ECONOMIC EVALUATION OF REMOVAL PROCESSES
}

\author{
Lucas Campaner Alves
}

\begin{abstract}
The sludge generated in electroplating processes is classified by NBR $10.004 / 04$ as a hazardous material (class I). In the literature, few studies report the recovery of chromium present in the electroplating sludge generated in the industries. In this sense, the present study conducted the removal of chromium in the electroplating sludge through two different processes, aiming to evaluate their efficiency and economic viability. The first process removed calcium through the use of citric acid being performed by varying the ratio of citric acid/calcium hydroxide $(2.5,5.5$ and 8.0). Then, were performed the leaching of the samples. According to the literature, the efficiency of the oxidation process varies depending on the reaction temperature, time and concentration of hydrogen peroxide. For this reason, samples were heated to a temperature ranging from $40^{\circ} \mathrm{C}, 60^{\circ} \mathrm{C}$ and $80^{\circ} \mathrm{C}$. Also, were conducted variations in the concentrations of hydrogen peroxide (1.5, 3.0 and 4.5 mol.L $\left.{ }^{-1}\right)$ and reaction time (30, 60 and 90 minutes). The second Process consisted in the chrome recovery by using the galvanic sludge without removal of the calcium and acid leaching. The chrome oxidation occurred by the same method shown in Process 1. Elemental characterization of the samples determined that the primary sludge constituent was calcium (20.05\% by weight), and in terms of heavy metals, the chromium and the nickel $(6.52 \%$ and $4.33 \%$ by mass, respectively). Most of calcium removal efficiency was obtained at a rate of 8 with $51.76 \%$ by mass, then the ratio of 5.50 to $36.75 \%$ by mass and 2.50 to $24.83 \%$ by mass. The best oxidation result of chromium in Process 1 was obtained

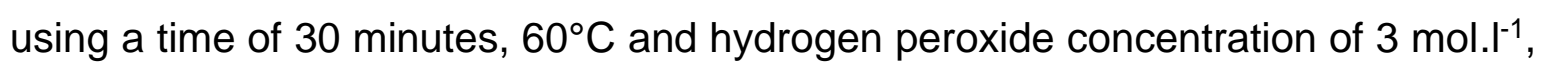
with 41.09 wt\% efficiency. In Process 2 was obtained the removal of $37.96 \%$ by mass of chromium temperature of $80^{\circ} \mathrm{C}$, for one hour and $3,00 \mathrm{~mol}^{-1} \mathrm{l}^{-1}$ of hydrogen peroxide. Evaluating the costs for chrome removal of the two processes was
\end{abstract}


determined that the Process 1 was more costly than 2, but both showed no economic feasibility for implementation on an industrial scale. However, in both cases occurred the oxidation of chromium present in the electroplating sludge, allowing its removal from the residue. Thus, environmental gains have been achieved by the reduction of this element in electroplating waste, which mostly is intended for landfill class I, generating an environmental liability. 


\section{SUMÁRIO}

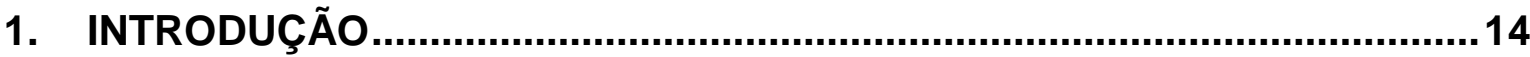

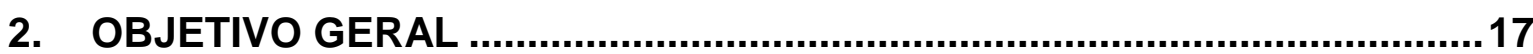

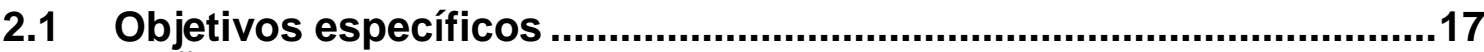

3. REVISÃO DA LITERATURA

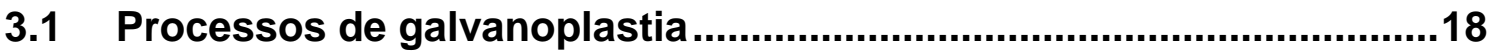

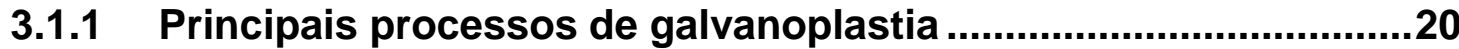

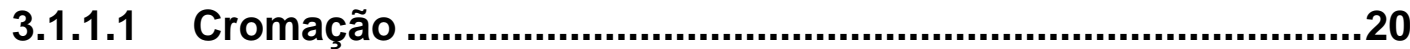

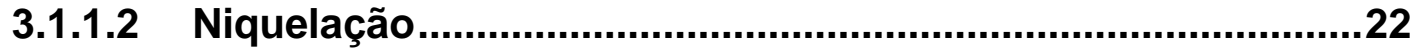

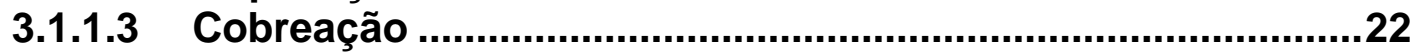

3.1.1.4 Zincagem ...........................................................................22

3.1.2 Sistema de Tratamento Convencional de Efluentes ....................23

3.2 Resíduos sólidos ...........................................................................27

3.2.1 Classificação dos resíduos sólidos - ABNT NBR 10.004/04 .........30

3.2.2 Resíduos Sólidos de Galvanoplastia ..........................................32

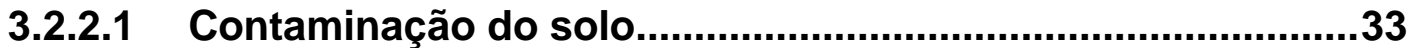

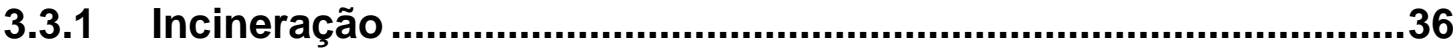

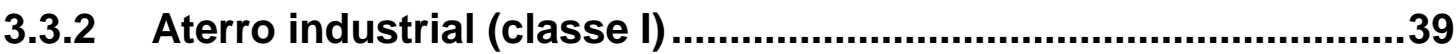

3.3.3 Coprocessamento .......................................................................

3.3.4 Aplicação em vidro e matriz cerâmica .........................................42

3.4 Processos de remoção de metais do lodo de galvanoplastia ............43

3.4.1 Recuperação de zinco, cobre e níquel por processos

pirometalúrgico e hidrometalúrgico.

3.4.2 Recuperação de cobre e níquel por lixiviação e eletrodeposição 45

3.4.3 Recuperação do cromo de lodo de galvanoplastia por oxidação46

3.4.4 Recuperação seletiva do cobre, zinco, níquel e cromo por

processo de sulfetação e oxidação...............................................................

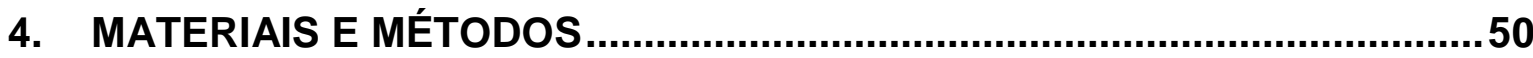

4.1 Coleta do resíduo sólido galvânico ....................................................50

4.2 Preparação e caracterização da amostra........................................51

4.2.1 Preparação da amostra de lodo galvânico ...................................51

4.2.2 Caracterização do Lodo Galvânico …….....................................52

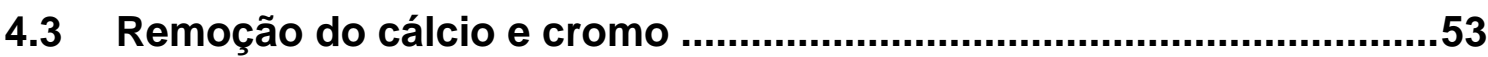

4.3.1 Remoção do cálcio e recuperação do cromo ...............................54

4.3.1.1 Remoção do cálcio ............................................................54

4.3.1.2 Recuperação do cromo por processo de lixiviação ...............56

4.3.2 Recuperação do cromo sem o processo de lixiviação ..................61 


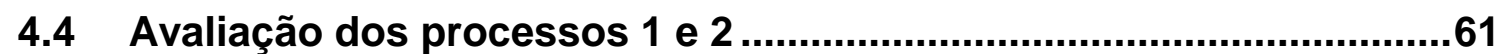

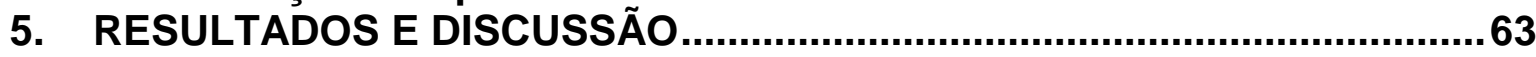

5.1 Preparação e caracterização do lodo de galvanoplastia .....................63

5.1 PROCESSO 1 - REMOÇÃO DO CÁLCIO E CROMO ...............................65

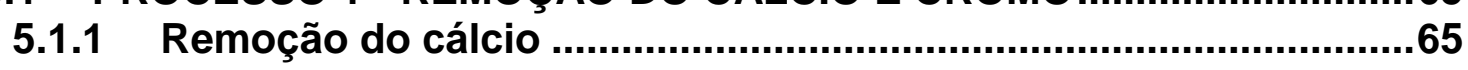

5.1.2 Recuperação do cromo por processo de lixiviação .....................69

5.1.2.1 Processo de lixiviação da amostra ........................................69

5.1.2.2 Processo de oxidação do cromo ...........................................71

5.1.3 Recuperação do cromo sem o processo de lixiviação ...................76

5.1.4 Comparação entre o processo 1 e o processo 2 ............................82

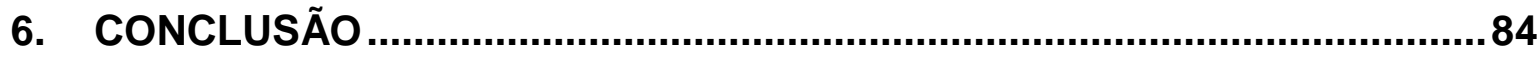

APÊNICE A - Tabela contendo a composição mássica do lodo de

galvanoplastia realizada por FRX-EDX.

APÊNDICE B - Tabela contendo a composição mássica do filtrado na etapa

de remoção do cálcio no Processo 1.

APÊNDICE C - Custos dos processos de remoção do cromo em dólar

comercial, cotado dia 20/05/2015.

APÊNDICE D - Tabela contendo a composição mássica do precipitado da etapa de remoção do cálcio no Processo 1.

APÊNDICE E - Tabela contendo a composição mássica do precipitado das

três lixiviações ácidas.

APÊNDICE F - Tabela contendo a composição mássica do precipitado das oito amostras do Processo 1, realizada por FRX-EDX. 90

APÊNDICE G - Tabela contendo a composição mássica do precipitado das sete amostras do Processo 2, realizada por FRX-EDX....................................91

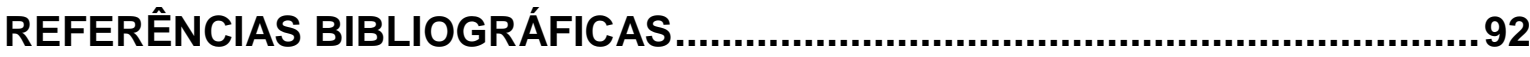




\section{LISTA DE TABELAS}

TABELA 1 - PRINCIPAIS VANTAGENS E DESVANTAGENS DOS SISTEMAS DE TRATAMENTO PARA REMOÇÃO DE METAIS PESADOS.

TABELA 2 - INSTALAÇÕES LICENCIADAS PARA MANUSEIO DE RESÍDUOS SÓLIDOS INDUSTRIAIS

TABELA 3 - PRINCIPAIS ELEMENTOS QUÍMICOS PRESENTES NO LODO DE GALVANOPLASTIA, OBTIDOS PELAS ANÁLISES DE ICP-OES E CROMATOGRAFIA GASOSA.

TABELA 4 - CARACTERIZAÇÃO DAS TRÊS AMOSTRAS FILTRADAS E EFICIÊNCIA DO PROCESSO DE REMOÇÃO DO CÁLCIO. .66

TABELA 5 - CUSTO DA EXTRAÇÃO DO CÁLCIO BASEADO NA MASSA DE ÁCIDO CÍTRICO.

TABELA 6 - ANÁLISE DAS AMOSTRAS LIXIVIADAS PELA TÉCNICA DE ICPOES.

TABELA 7 - CUSTOS DA LIXIVIAÇÃO ÁCIDA POR GRAMA DE LODO DE GALVANOPLASTIA, CONSIDERANDO OS TRÊS AGENTES EXTRATORES. .70

TABELA 8 - EFICIÊNCIA DO PROCESSO DE REMOÇÃO DO CROMO VARIANDO A TEMPERATURA, TEMPO E CONCENTRAÇÃO $\mathrm{H}_{2} \mathrm{O}_{2}$.

TABELA 9 - BALANÇO DE MASSA DE CROMO NA ETAPA DE OXIDAÇÃO DO PROCESSO 1

TABELA 10 - EFICIÊNCIA DO PROCESSO DE REMOÇÃO DO CROMO VARIANDO A TEMPERATURA, TEMPO E CONCENTRAÇÃO $\mathrm{H}_{2} \mathrm{O}_{2}$

TABELA 11 - BALANÇO DE MASSA DE CROMO NA ETAPA DE OXIDAÇÃO DO PROCESSO 2

TABELA 12 - CUSTO DOS PROCESSOS DE REMOÇÃO DO CROMO POR GRAMA DE LODO DE GALVANOPLASTIA.

TABELA 13 - CUSTO EM DÓLAR DA EXTRAÇÃO DO CÁLCIO BASEADO NA MASSA DE ÁCIDO CÍTRICO.

TABELA 14- CUSTOS EM DÓLAR DA LIXIVIAÇÃO ÁCIDA POR GRAMA DE LODO DE GALVANOPLASTIA, CONSIDERANDO OS TRÊS AGENTES EXTRATORES

TABELA 15 - CUSTO EM DÓLAR DOS PROCESSOS DE REMOÇÃO DO CROMO POR GRAMA DE LODO DE GALVANOPLASTIA. 


\section{LISTA DE FIGURAS}

FIGURA 1 - FLUXOGRAMA DAS PRINCIPAIS ETAPAS ENVOLVIDAS NO

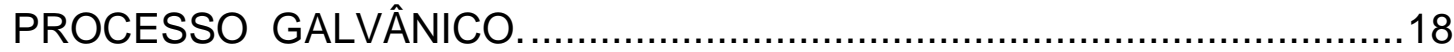

FIGURA 2 - TRATAMENTO DE EFLUENTES POR BATELADA. .....................26

FIGURA 3 - TRATAMENTO E DISPOSIÇÃO FINAL DE RESÍDUOS INDUSTRIAIS (CLASSE I) NO ESTADO DE SÃO PAULO

FIGURA 4 - GERAÇÃO DE RESÍDUOS CLASSE I POR TIPOLOGIA

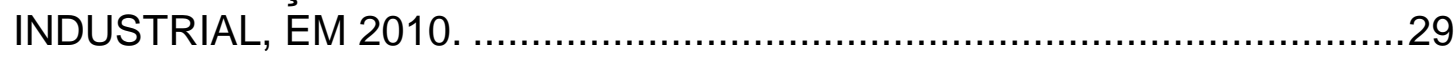

FIGURA 5 - FLUXOGRAMA DE CLASSIFICAÇÃO DOS RESÍDUOS .................31

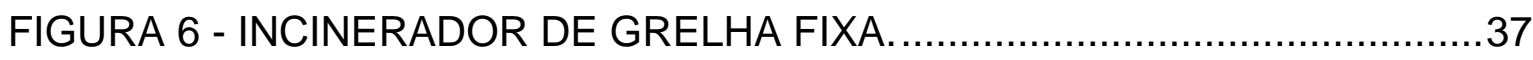

FIGURA 7 - INCINERADOR DE FORNOS ROTATIVOS.................................38

FIGURA 8 - PROCESSO DE SULFETAÇÃO..................................................48

FIGURA 9 - FLUXOGRAMA DO PROCEDIMENTO EXPERIMENTA. ................50

FIGURA 10 - TAMBORES DE ACONDICIONAMENTO DE LODO GALVÂNICO

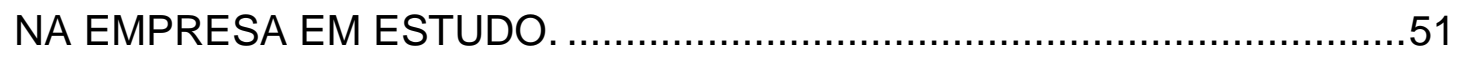

FIGURA 11 - SECAGEM DO LODO DE GALVANOPLASTIA NA ESTUFA A \pm

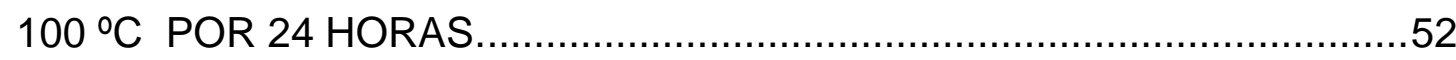

FIGURA 12 - HOMOGENEIZAÇÃO DA AMOSTRA A 700 RPM PARA PROPICIAR A REAÇÃO ENTRE O CÁLCIO E O ÁCIDO CÍTRICO. 55

FIGURAS 13 E 14 - PROCESSO UTILIZADO PARA FILTRAÇÃO DAS AMOSTRAS.

FIGURA 15 - FLUXOGRAMA DO PROCESSO DE LIXIVIAÇÃO ÁCIDO COM

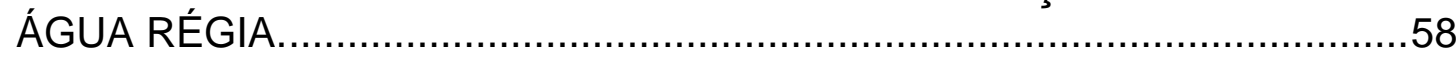

FIGURAS 16 E 17 - PROCESSO DE OXIDAÇÃO DO CROMO.........................59

FIGURA 18 - COMPOSIÇÃO MÁSSICA DO LODO DE GALVANOPLASTIA......63 FIGURA 19 - EFICIÊNCIA DO PROCESSO DE REMOÇÃO DO CÁLCIO EM FUNÇÃO DA RAZÃO MÁSSICA DE ÁCIDO CÍTRICO/HIDRÓXIDO DE CÁLCIO.

FIGURA 20 - COMPOSIÇÃO MÁSSICA DAS TRÊS AMOSTRAS FILTRADAS. 66 FIGURA 21 - COMPOSIÇÃO MÁSSICA DO PRECIPITADO REMOVIDO POR FILTRAÇÃO. 68

FIGURA 22 - COMPOSIÇÃO MÁSSICA DO PRECIPITADO DAS TRÊS LIXIVIAÇÕES ÁCIDASS. .70

FIGURA 23 - EFICIÊNCIA DO PROCESSO DE REMOÇÃO DE CROMO EM FUNÇÃO DA VARIAÇÃO DA TEMPERATURA. 72

FIGURA 24 - EFICIÊNCIA DO PROCESSO DE REMOÇÃO DE CROMO EM FUNÇÃO DA VARIAÇÃO DO TEMPO DE REAÇÃO. 73

FIGURA 25 - EFICIÊNCIA DO PROCESSO DE REMOÇÃO DE CROMO EM FUNÇÃO DA VARIAÇÃO DA CONCENTRAÇÃO DE $\mathrm{H}_{2} \mathrm{O}_{2}$ 
FIGURA 26 - COMPOSIÇÃO MÁSSICA DO PRECIPITADO DAS OITO AMOSTRAS DO PROCESSO 1.

FIGURAS 27 E 28 - CADINHO DE ALUMINA APÓS A CALCINAÇÃO DAS AMOSTRAS PRECIPITADAS DO PROCESSO 1.

FIGURA 29 - EFICIÊNCIA DO PROCESSO DE REMOÇÃO DE CROMO SEM

LIXIVIAÇÃO EM FUNÇÃO DA VARIAÇÃO DA TEMPERATURA.

FIGURA 30 - EFICIÊNCIA DO PROCESSO DE REMOÇÃO DE CROMO SEM

LIXIVIAÇÃO EM FUNÇÃO DA VARIAÇÃO DO TEMPO DE REAÇÃO......

FIGURA 31 - EFICIÊNCIA DO PROCESSO DE REMOÇÃO DE CROMO SEM LIXIVIAÇÃO EM FUNÇÃO DA VARIAÇÃO DA CONCENTRAÇÃO DE $\mathrm{H}_{2} \mathrm{O}_{2}$.

FIGURA 32 - ESPUMA DENSA FORMADA SOBRE AS AMOSTRAS DO PROCESSO 2

FIGURA 33 - COMPOSIÇÃO MÁSSICA DO PRECIPITADO DAS SETE AMOSTRAS DO PROCESSO 2 .80

FIGURA 34 E 35- CADINHO DE ALUMINA APÓS A CALCINAÇÃO DAS AMOSTRAS PRECIPITADAS DO PROCESSO 2. 


\section{LISTA DAS PRINCIPAIS ABREVIATURAS}

ABNT - Associação Brasileira de Normas Técnicas

ATSDR - Agency for Toxic Substances and Disease Registry

CCTM - Centro de Ciência e Tecnologia de Materiais

CETESB - Companhia Ambiental do Estado de São Paulo

CONAMA - Conselho Nacional do Meio Ambiente

$\mathrm{CPRH}$ - Companhia Pernambucana do Meio Ambiente

CQMA - Centro de Química e Meio Ambiente

Cromo (VI) - Cromo hexavalente

Cromo (III) - Cromo trivalente

EPI - Equipamento de Proteção Individual

ETE - Estação de Tratamento de Efluentes

$\mathrm{K}$ - Temperatura em Kelvin

FRX-EDX - Espectrometria de Fluorescência de Raios X por Energia Dispersiva

g. $\mathrm{L}^{-1}-$ Gramas por litro

ICP-OES - Espectrometria de Emissão Óptica de Plasma de Argônio

mol. $\mathrm{L}^{-1}-\mathrm{Mol}$ por litro

IBAM - Instituto Brasileiro de Administração Municipal

$\mathrm{mL}-$ Mililitros

$\mathrm{mm}$ - Milímetros

NBR - Norma Brasileira Regulamentadora

rpm - Rotações por minuto

SEBRAE/RJ - Serviço de Apoio às Micro e Pequenas Empresas no Estado do Rio de Janeiro

SENAI/RS - Serviço Nacional de Aprendizagem Industrial/Rio Grande do Sul SESI - Serviço Social da Indústria

$\mathrm{pH}$ - Potencial hidrogeniônico

WHO - World Health Organization 


\section{LISTA DE SIMBOLOS E COMPOSTOS QUIMICOS}

$\mathrm{Ca}_{3}\left(\mathrm{C}_{6} \mathrm{H}_{5} \mathrm{O}_{7}\right)_{2}$ - citrato e cálcio

$\mathrm{Ca}\left(\mathrm{CrO}_{4}\right)$ - cromato de cálcio

$\mathrm{Ca}(\mathrm{OH})_{2}$ - hidróxido de cálcio

$\mathrm{CO}_{2}$ - dióxido de carbono

$\mathrm{CrCl}_{3} \cdot 6 \mathrm{H}_{2} \mathrm{O}$ - cloreto de cromo hidratado

Cr-O-Cr - óxido de cromo

$\mathrm{Cr}_{2} \mathrm{O}_{7}^{2-}-$ dicromato

$\mathrm{Cr}-\mathrm{OH}-\mathrm{Cr}$ - hidróxido de cromo

CuS - sulfeto de cobre

${ }^{\circ} \mathrm{C}$ - graus Celsius

$\mathrm{H}_{3} \mathrm{C}_{6} \mathrm{H}_{5} \mathrm{O}_{7}$ - ácido cítrico

$\mathrm{HCl}$ - ácido clorídrico

HCN - cianeto de hidrogênio

$\mathrm{H}_{2} \mathrm{Cr}_{2} \mathrm{O}_{7}$ - ácido crômico

$\mathrm{HNO}_{3}$ - ácido nítrico

$\mathrm{H}_{2} \mathrm{O}$ - água

$\mathrm{H}_{2} \mathrm{O}_{2}$ - peróxido de hidrogênio

$\mathrm{H}_{2} \mathrm{SO}_{4}$ - ácido sulfúrico

$\mathrm{NaOH}$ - hidróxido de sódio

ppm - partes por milhão

$\mathrm{SO}_{2}$ - dióxido de enxofre

$w t \%$ - porcentagem mássica

ZnS - sulfeto de zinco 


\section{INTRODUÇÃO}

O processo galvânico consiste na deposição de uma camada fina de metal sobre uma superfície metálica ou plástica, por meios químicos ou eletroquímicos, com o objetivo de melhorar a resistência à corrosão, a durabilidade, além de propiciar uma aparência mais atrativa (NETO et al., 2008; SESI, 2007; BRAILE; CAVALCANTI, 1993).

A deposição metálica ocorre, em praticamente toda sua totalidade, em tanques contendo soluções alcalinas ou ácidas. Os banhos utilizados no processo galvânico são divididos em: banhos eletrolíticos, que utilizam corrente elétrica para realizar a deposição metálica ou limpeza das peças e banhos de imersão simples, que não utilizam a eletricidade (BRAILE; CAVALCANTI, 1993).

As etapas constituintes do processo galvânico são (PACHECO, 2002; SENAI-RS, 2002):

- Pré-tratamento - etapa onde ocorre a preparação da superfície das peças, por processos mecânicos e/ou químicos, visando garantir ao revestimento metálico boa aderência, uniformidade e aparência.

- Tratamento - processo de deposição metálica por meio de banhos eletrolítico ou de imersão simples (químico). Esta etapa pode se desenvolver numa sequência de banhos, que variam de acordo com o processo utilizado.

- Pós-tratamento - etapa de finalização do processo, onde as peças podem passar por lavagem com água fria ou quente; secagem em centrífuga, estufa ou jatos de ar; banho de óleo para embalagem e proteção; e pintura ou envernizamento.

Os processos de deposição metálica se enquadram no setor industrial de potencial risco ambiental, pois os efluentes gerados contêm quantidades consideráveis de ácidos e metais pesados, tais como o zinco, ferro, cromo, níquel, cobre, entre outros (MANSUR et al., 2008 e KURNIAWAN et al., 2006).

Para atender a legislação ambiental vigente e reduzir os possíveis impactos ambientais, utiliza-se nas empresas de galvanoplastia um sistema de tratamento de efluentes, responsável pela remoção das substâncias tóxicas antes da descarga no meio ambiente (MARDER et al., 2003). 
A precipitação de hidróxidos metálicos tem sido o processo mais utilizado para tratar efluentes galvânicos, principalmente pelo fato da tecnologia e agentes alcalinizantes utilizados (principalmente o hidróxido de cálcio) serem de baixo custo. Este sistema pode envolver várias etapas, se iniciando pela redução do cromo hexavalente para trivalente em condições ácidas. Em seguida é realizada a neutralização pela adição de hidróxido de cálcio ou hidróxido de sódio até $\circ \mathrm{pH}$ atingir valor próximo a 8,5. Os flocos em suspensão resultantes da floculação precipitam formando o lodo de galvanoplastia, encaminhado para filtragem para remover parcialmente a água do sólido. Este resíduo galvânico é classificado pela ABNT NBR 10.004/04 como perigoso (classe I) devido sua toxicidade (MANSUR et al., 2008; NETO et al., 2008; MAGALHÃES et al., 2005).

As estações de tratamento de efluentes utilizadas em processos de deposição metálica geram uma grande quantidade de lodo galvânico que deve ser armazenado e destinado adequadamente, constituindo ônus econômicos e riscos de contaminação ambiental às indústrias envolvidas (MILANEZ et.al. 2005; MARDER et al., 2003).

Apesar da precipitação com hidróxidos metálicos ser um método eficiente de tratamento de efluentes, tanto os ácidos quanto os metais presentes no lodo galvânico não são recuperados. Além disso, este sistema tem como desvantagens a grande quantidade de produtos utilizados no tratamento e o elevado custo para destinação ambientalmente correta do lodo de galvanoplastia. Por estes motivos, vem aumentando o interesse em novos processos de tratamento que gerem menos resíduos sólidos e/ou que permitem a recuperação dos produtos que possuam valor para serem reciclados ou reutilizados (MANSUR et al., 2008).

Algumas das alternativas de destinação de resíduos de galvanoplastia vêm sendo estudadas nos últimos anos. A incorporação de resíduos galvânicos em vidro de silicato apresentaram características interessantes, tais como alta resistência ao ataque hidrolítico, média resistência ao ataque alcalino e baixa resistência ao ataque ácido.

A adição de $20 \%$ a $30 \%$ wt de lodo de galvanoplastia aumenta a resistência ao ataque hidrolítico e ao ataque alcalino, quando comparado ao vidro analisado sem a adição deste resíduo (SILVA; MELLO-CASTANHO, 2004). 
Rossini e Bernardes (2006) elaboraram um sistema para a recuperação seletiva de cobre, níquel, e zinco presentes no lodo galvânico pelo processo de sulfatação, utilizando como agente a pirita (resíduos de carvão). O melhor resultado do ponto de vista da recuperação dos metais e da viabilidade econômica do processo foi encontrado na proporção de 1:0,4 de lodo galvânico/pirita a $550{ }^{\circ} \mathrm{C}$ de temperatura por $90 \mathrm{~min}$. Estas condições conduzem a uma recuperação de $60 \%$ de zinco, $50 \%$ de cobre e $43 \%$ de níquel.

O trabalho realizado por Kuchar et al. (2010) estudou a recuperação seletiva do cobre, zinco, níquel e cromo presentes no lodo galvânico pelos processos sulfetação combinado ao de oxidação. Este tratamento obteve uma eficiência de recuperação de $96 \%$ de cobre, $91 \%$ de zinco, $64 \%$ de níquel e $59 \%$ de cromo.

Silva et al. (2006) realizou a extração e recuperação do cromo oriundo dos resíduos oriundos de uma indústria de galvanoplastia. O resultado da extração do cromo foi elevado, variando de $87,50 \%$ a $99,70 \%$, além de solubilizar praticamente todo o resíduo. A eficiência do processo de recuperação de cromo foi de cerca de $92,50 \%$ utilizando o tempo de 40 minutos, a temperatura de $60^{\circ} \mathrm{C}$ e a concentração de $\mathrm{H}_{2} \mathrm{O}_{2}$ de 1,4 mol. $\mathrm{L}^{-1}$.

$\mathrm{Na}$ literatura encontram-se poucos trabalhos referentes à recuperação do cromo presente no lodo gerado em sistemas de tratamento de efluentes de indústrias de galvanoplastia. Os métodos de recuperação deste metal não são economicamente viáveis em larga escala, sendo necessárias pesquisas adicionais sobre o tema.

Os processos de remoção do cromo apresentados em literatura realizam a lixiviação ácida do lodo de galvanoplastia antes da etapa de oxidação com peróxido de hidrogênio. Neste sentido, o presente estudo avaliou à simplificação do processo de oxidação convencional, por meio da remoção da etapa de lixiviação, visando à otimização do processo e redução dos seus custos. Para se estabelecer uma comparação entre o método proposto e o apresentado em literatura determinou-se a eficiência e os custos de ambos, permitindo assim identificar qual proporciona a melhor relação custo/benefício. 


\section{OBJETIVO GERAL}

Realizar a remoção do cromo presente no lodo de galvanoplastia por meio de dois processos, sendo o primeiro formado por uma etapa de remoção do cálcio seguido pela oxidação do cromo, de acordo com a metodologia apresentada na literatura, e o segundo uma simplificação do processo de oxidação, visando avaliar à eficiência e a viabilidade econômica dos dois processos.

\subsection{Objetivos específicos}

- Avaliar a eficiência do processo de remoção do cálcio em função da razão mássica de ácido cítrico/hidróxido de cálcio;

- Determinar a influência da lixiviação ácida na eficiência do processo de oxidação do cromo;

- Verificar a influência do tempo de reação, da temperatura e da concentração de peróxido de hidrogênio na eficiência dos processos de oxidação;

- Avaliar a viabilidade econômica dos dois processos de remoção do cromo. 


\section{REVISÃO DA LITERATURA}

Abordou-se neste item aspectos gerais e teóricos relacionados a processos galvânicos, resíduos sólidos e sua destinação final e aspectos específicos associados a resíduos sólidos galvânicos, as legislações ambientais relacionadas ao estudo, a recuperação de metais.

\subsection{Processos de galvanoplastia}

O processo de galvanoplastia envolve uma sequência de banhos, constituído basicamente pelas etapas de pré-tratamento, de revestimento (tratamento) e de pós-tratamento. Conforme apresentado na Figura 1, estas três etapas geram como subprodutos emissões gasosas, efluentes e resíduos sólidos perigosos que precisam de tratamento.

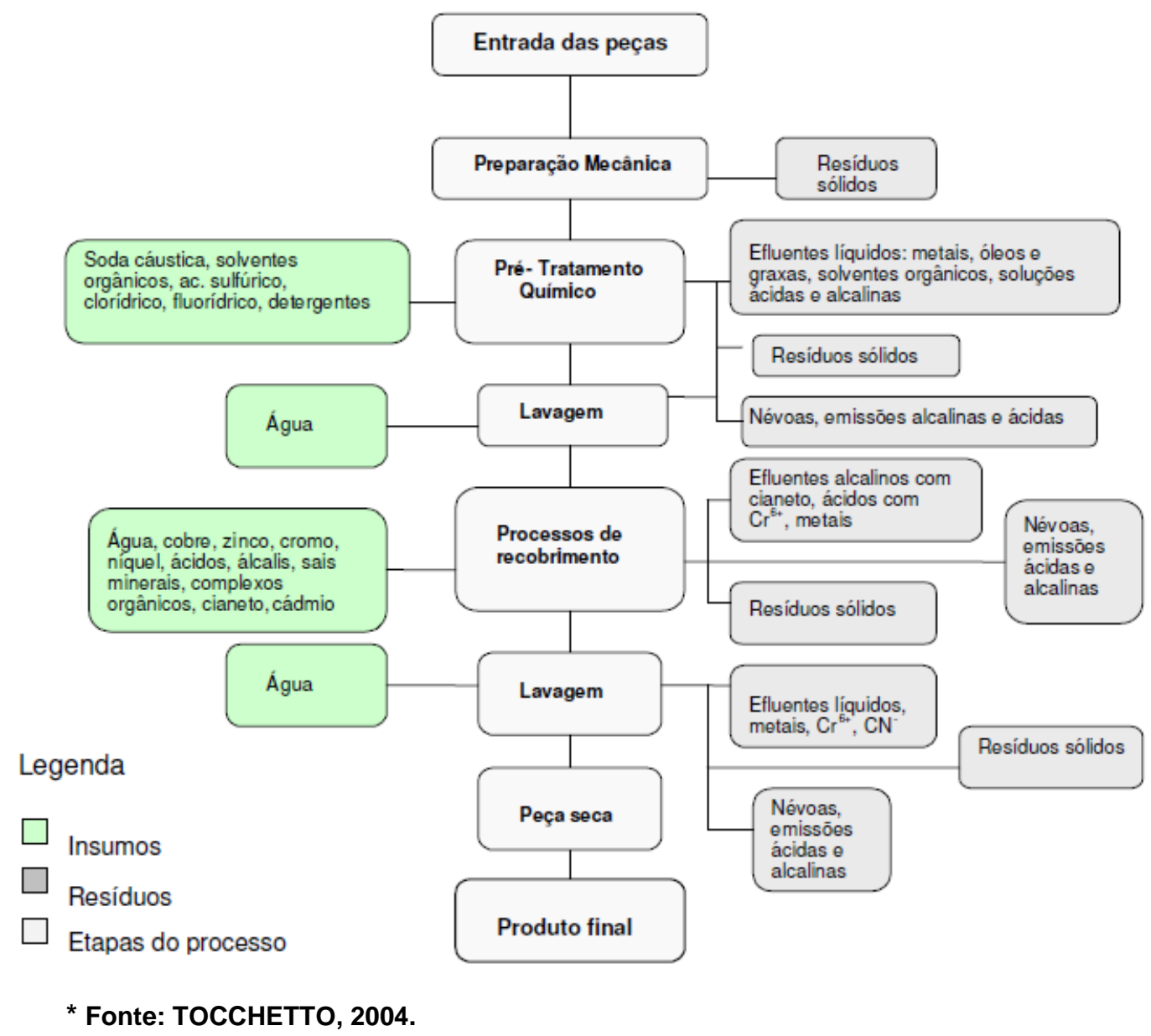

Figura 1 - Fluxograma das principais etapas envolvidas no processo galvânico. 
A preparação mecânica das peças é a primeira etapa do processo galvânico, que proporciona às peças uma superfície mais lisa e homogênea pela remoção de suas rebarbas, irregularidades, camadas de óxidos e resíduos de tintas e/ou de solda. Realiza-se esta etapa por processos como escovação, lixamento, jateamento e polimento, esmerilhamento e entre outros (PACHECO, 2002; SENAI-RS, 2002), gerando resíduos sólidos como fragmentos de metal base.

A presença de camadas de óleos, graxas, poeira e óxidos, formados pelo contato como ar, na superfície da peça prejudica a deposição metálica, utilizandose para a remoção destas impurezas a etapa de pré-tratamento químico, composta pelos processos de desengraxe e decapagem (PACHECO, 2002; SENAI-RS, 2002).

O processo de desengraxe é considerado como pré-tratamento por não incorporar elementos às peças, visando apenas à remoção de gorduras, graxas e poeira metálica. A presença dessas impurezas beneficia a formação de manchas e reduz a aderência do recobrimento metálico, sendo grande parte gerada na etapa de preparação mecânica. Dentre vários métodos de desengraxe, o mais simples, rápido, eficiente e menos impactante ao meio ambiente é o que utiliza solução alcalina (CETESB, 2005; TOCCHETTO, 2004). Nessa etapa, como pode ser observado na Figura 1, utiliza-se uma mistura aquosa contendo soda cáustica e solventes, responsável pela geração de emissões gasosas que podem ser tóxicos e efluentes alcalinos contendo metais, solventes orgânicos, óleos e graxas.

A decapagem ácida tem como objetivo remover os óxidos e/ou a ferrugem existentes na superfície da peça, geralmente usando soluções de ácido sulfúrico ou ácido clorídrico que resultam na geração de efluentes ácidos e gases. Em geral, utiliza-se este processo por meio da imersão das peças em um tanque de solução ácida por determinado período de tempo. O processo de decapagem devese às reações entre o ácido e os óxidos. Quando são eliminadas as camadas de óxidos o ácido ataca o metal base, podendo formar imperfeições na superfície das peças. Por este fato são utilizados aditivos chamados "inibidores", que retardam o ataque do ácido ao metal base após a remoção das camadas de óxidos. Antes de prosseguir, as peças que passaram pela decapagem devem passar pela lavagem (CETESB, 2005; TOCCHETTO, 2004). 
Entre as etapas de desengraxe e decapagem é necessário à lavagem das peças com água, no processo denominado lavagem. Essa etapa visa minimizar a contaminação entre as etapas do processo e garantir que a peça possua condições de serem recobertas com a qualidade (TOCCHETTO, 2004).

Realizadas as etapas de pré-tratamento (preparação mecânica e pré-tratamento químico), encaminham-se as peças para a deposição eletrolítica, também conhecida como deposição metálica. Os vários tipos de metais presentes nesta etapa variam de acordo com o processo produtivo, sendo os principais detalhados no item 3.1.1.

Com o passar do tempo, ou mesmo em virtude de algumas operações de tratamento, ocorre à oxidação das peças que impedem deposição dos metais. A ativação ácida garante a aderência da próxima camada utilizando soluções ácidas de baixa concentração para remoção dessas camadas de óxidos. Utiliza-se geralmente o ácido sulfúrico, mas também são empregados os ácidos: clorídrico, fosfórico ou nítrico (CETESB, 2005).

\subsubsection{Principais processos de galvanoplastia}

Existem diversos processos de galvanoplastia utilizados pelas empresas, dentre eles destaca-se a cromação, cobreação, niquelação, zincagem, estanhagem, zincagem, folheados, pintura, entre outros. Estes processos possuem uma sequência específica de banhos eletrolíticos, que variam em função do uso previsto para as peças.

\subsubsection{Cromação}

A cromação é dividida, principalmente, em duas grandes classes, sendo elas a de cromo decorativo e cromo duro. O cromo duro consiste na deposição de uma grossa camada do metal diretamente sobre à superfície da peça. Essa deposição proporciona uma melhor dureza, resistência à abrasão, boa resistência à corrosão, baixo coeficiente de friç̧ão, alta resistência ao calor. O cromo duro é utilizado em vários produtos como, por exemplo, anéis, rolamentos, eixos, cilindros, ferramentas de corte (CNRH, 2001; RAMANATHAN, 1990). 
O cromo decorativo consiste na aplicação de uma camada fina do metal $(0,25$ a $0,75 \mathrm{~mm})$ sobre outros metais previamente depositados, com a intenção de prevenir manchas, aumentar a resistência à abrasão, além de melhorar o aspecto visual da peça. Geralmente as empresas utilizam, antes da deposição do cromo, banhos de cobre (cobre alcalino e cobre ácido) e níquel brilhante $(\mathrm{CPRH}$, 2001, FÖLDES, 1973).

O cobre pode ser depositado por meio de dois tipos de banhos: alcalinos e ácidos. O cobre alcalino propicia as peças uma boa aderência às camadas metálicas que serão depositadas e as protege contra o ataque ácido dos banhos seguintes, sendo geralmente à base de cianetos e pirofosfatos $(\mathrm{CPRH}, 2001$, FÖLDES, 1973).

O cobre ácido é utilizado para nivelar a superfície das peças, proporcionar brilho e colaborar para a proteção contra corrosão, sendo à base de sulfato, sulfamato ou fluorborato. Os dois tipos de banhos podem ser utilizados em sequência, iniciando pelo banho de cobre alcalino e seguido pelo banho de cobre ácido (CPRH, 2001, FÖLDES, 1973).

O banho de níquel possui como principal objetivo proteger as peças da corrosão, pois é um metal duro muito resistente ao ataque químico de diversos ácidos, bases e da água. Utiliza-se muito o níquel para fins decorativos, podendo ser brilhante ou fosco. Sua eletrodeposição ocorre por meio da aplicação de uma corrente elétrica em uma solução aquosa contendo sais de níquel. A diminuição da concentração dos íons de hidrogênio causam o aumento de $\mathrm{pH}$, resultando em hidrólise do níquel e formação de lodo no tanque. Para garantir a eficiência dos banhos é necessário controlar o pH por meio da deposição de ácidos para sua correção (CPRH, 2001, FÖLDES, 1973).

O banho de níquel tipo Watts é o mais empregado por ser considerado o mais simples, barato e de fácil de manter livre de impurezas. O sulfato de níquel é a principal fonte de íons do metal na solução Watts $(\mathrm{CPRH}, 2001$; RAMANATHAN, 1990).

Porém, o níquel em contato com o ar perde rapidamente o brilho. Por este motivo, geralmente, após sua deposição a peça é encaminhada para o banho de cromo para manter o brilho (CPRH, 2001; RAMANATHAN, 1990). 
O processo de deposição do cromo ocorre em uma solução aquosa de ácido crômico e catalizadores, sendo os mais utilizados o sulfato e o fluoreto. $\mathrm{O}$ ácido crômico utilizado (principalmente $\mathrm{H}_{2} \mathrm{Cr}_{2} \mathrm{O}_{7}$ ) é o produto da reação entre o trióxido de cromo ou anidro crômico com a água. As principais fontes de sulfato são o sulfato de sódio e o ácido sulfúrico, já as de fluoreto são o fluoreto de silício e ácido flúor silício. A relação entre o ácido crômico e o catalizador pode variar entre 50:1 a 250:1, sendo a mais utilizada a 100:1 por ser a mais eficiente (CNRH, 2001; RAMANATHAN, 1990).

\subsubsection{Niquelação}

O processo de niquelação é constituído somente por banhos de cobre e níquel ou exclusivamente de níquel, não recebendo revestimento de cromo decorativo. Clipes e chaves são exemplos de peças que utilizam o processo de niquelação (FÖLDES, 1973).

\subsubsection{Cobreação}

Denomina-se de cobreação o processo que utiliza exclusivamente banhos de cobre. Este metal avermelhado é um bom condutor de calor e eletricidade, motivo pelo qual é utilizado em fios condutores e placas de circuito. No entanto, em contato com o ar oxida-se rapidamente, adquirindo uma camada de óxido sobre sua superfície. Por este motivo, acaba-se utilizando o cobre como camada intermediária para deposição de outros metais, como por exemplo, o níquel (CPRH, 2001, FÖLDES, 1973).

\subsubsection{Zincagem}

O zinco é um dos metais mais abundante na terra e possui como principal propriedade a proteção de peças de ferro contra corrosão. O processo de zincagem é muito utilizado por ser de fácil aplicação e por não ocasionar problemas de aderência. Sua utilização é vetada para embalagens de alimentos, devido 
ao zinco ser considerado tóxico. As camadas formadas possuem diferentes colorações, variando de acordo com sua espessura (CPRH, 2001).

As aplicações das camadas de zinco ocorrem por meios químicos (zincagem a fogo) ou eletrolíticos. A aplicação química da camada de zinco é realizada a altas temperaturas, em torno de $500^{\circ} \mathrm{C}$, motivo pelo qual é utilizada a zincagem eletrolítica para peças que sofrem deformações quando aquecidas. Geralmente o processo de zincagem é constituído pelas etapas de desengraxe, decapagem e deposição de zinco. Para aumentar a resistência à corrosão e à abrasão, além de melhorar a aparência, realiza-se a cromação após a zincagem (CPRH, 2001).

As concentrações clássicas de zinco contendo cianeto possuem boa penetração e poder de cobertura, são extremamente robustas e se depositam com aparência e espessura uniformes. Com as restrições ambientais para o uso do cianeto surgiu uma solução isenta de cianeto, porém além desse banho apresentar pouca robustez o metal depositado fica escuro e esponjoso. Outra solução alternativa para o uso do cianeto foi à utilização de banhos a base de cloreto que apresentam depósitos de excelente qualidade em uma vasta gama de substratos, porém essa solução prejudica a deposição de metais no sistema de tratamento de efluentes (CPRH, 2001).

Independentemente do banho de zinco utilizado à camada recém-formada é muito ativa, tornando-se muito susceptível a oxidação do zinco, conhecido como corrosão branca. Essa ação do ambiente sobre o zinco pode resultar em manchas, descoloração ou marcas de impressão digital caso as peças sejam manuseadas. Para retardar a corrosão branca e melhorar seu aspecto visual toda peça após receber a camada de zinco é encaminhada para o banho de cromação (CPRH, 2001).

\subsubsection{Sistema de Tratamento Convencional de Efluentes}

Segundo Valenzuela (2008), o processo de revestimento metálico gera grande volume de efluentes com concentrações elevadas de compostos metálicos, ácidos, aditivos e lamas metálicas, gerados principalmente por:

- Extravasamento dos tanques de preparação, lavagem e deposição eletrolítica; 
- Descarga do fundo dos tanques (purgas), utilizada para renovação completa dos banhos;

- Descarga dos lavadores de gases;

- Derrames e respingos, resultantes da transferência das peças entre as unidades.

Os efluentes gerados nas indústrias de galvanoplastia apresentam concentrações de metais variando de acordo com o processo utilizado (ROSSINI; BERNARDES, 2006). Estes efluentes são encaminhados para um sistema de tratamento, que refere como principal objetivo remover as substâncias tóxicas dos efluentes, evitando o descarte de poluentes que possam causar danos à saúde humana e ao meio ambiente (MARDER et al., 2003).

Entre as tecnologias existentes para tratamento de efluentes contendo metais pesados destacam-se a precipitação química, troca iônica, membrana de ultrafiltração, osmose reversa, membrana eletrolítica e precipitação eletroquímica, sendo suas principais vantagens e desvantagens apresentadas na Tabela 1.

Tabela 1 - Principais vantagens e desvantagens dos sistemas de tratamento para remoção de metais pesados

\begin{tabular}{|c|c|c|}
\hline $\begin{array}{c}\text { Tipo de } \\
\text { tratamento }\end{array}$ & Vantagens & Desvantagens \\
\hline $\begin{array}{l}\text { Precipitação } \\
\text { química }\end{array}$ & $\begin{array}{l}\text { Baixo custo operacional; } \\
\text { Tecnologia simplificada; } \\
\text { Considerado eficiente para } \\
\text { efluentes com elevadas } \\
\text { concentrações de metais. }\end{array}$ & $\begin{array}{l}\text { Geração de lodo galvânico; } \\
\text { Custos para destinação do lodo } \\
\text { galvânico. }\end{array}$ \\
\hline Troca lônica & $\begin{array}{c}\text { Não gera lodo galvânico; } \\
\text { Menor período de tempo; } \\
\text { Eficiência de remoção de cromo } \\
\text { superior a 95\%. }\end{array}$ & $\begin{array}{l}\text { Nem toda a resina de troca } \\
\text { iónica é adequada para a } \\
\text { remoção de metais; } \\
\text { Elevado custo operacional; }\end{array}$ \\
\hline $\begin{array}{c}\text { Membrana de } \\
\text { ultrafiltração }\end{array}$ & $\begin{array}{c}\text { Sistema compacto; } \\
\text { Atinge a eficiência de 95\% para } \\
\text { remoção de cromo. }\end{array}$ & $\begin{array}{l}\text { Elevado custo operacional; } \\
\text { Suscetível a entupimento da } \\
\text { membrana. }\end{array}$ \\
\hline
\end{tabular}




\begin{tabular}{|c|c|c|}
\hline $\begin{array}{c}\text { Tipo de } \\
\text { tratamento }\end{array}$ & Vantagens & Desvantagens \\
\hline $\begin{array}{l}\text { Osmose } \\
\text { reversa }\end{array}$ & $\begin{array}{l}\text { Atinge a eficiência de } 97 \% \text { para } \\
\text { remoção de metais pesados; } \\
\text { Capaz de resistir a elevadas } \\
\text { temperaturas. }\end{array}$ & $\begin{array}{l}\text { Elevado consumo de energia } \\
\text { elétrica, devido à alta pressão } \\
\text { necessária; } \\
\text { Suscetível a entupimento da } \\
\text { membrana. }\end{array}$ \\
\hline $\begin{array}{l}\text { Membrana } \\
\text { eletrolítica }\end{array}$ & $\begin{array}{c}\text { Atinge a eficiência de } 98 \% \text { para } \\
\text { remoção de cromo. }\end{array}$ & $\begin{array}{c}\text { Elevado consumo de energia } \\
\text { elétrica. }\end{array}$ \\
\hline $\begin{array}{l}\text { Precipitação } \\
\text { eletroquímica }\end{array}$ & $\begin{array}{c}\text { Eficiência de remoção de cromo } \\
\text { superior a } 85 \% \text {. }\end{array}$ & $\begin{array}{c}\text { Elevado consumo de energia } \\
\text { elétrica. }\end{array}$ \\
\hline
\end{tabular}

* Fonte: Adaptado de Kurniawan et al., 2006.

A precipitação química de hidróxidos metálicos é o método mais utilizado nas indústrias galvânicas para tratar os seus efluentes, principalmente pelo fato dos equipamentos e agentes alcalinizantes utilizados (principalmente o hidróxido de cálcio) serem de baixo custo e ser considerado um processo de fácil operação (KURNIAWAN et al., 2006; SILVA et al., 2006).

Os sistemas de tratamento convencionais reduzem a toxicidade dos efluentes gerados por meio das etapas de coagulação, floculação e decantação, responsável pela formação do lodo galvânico (ROSSINI; BERNARDES, 2006). Os efluentes que na sua composição contém cromo ou cianeto devem conter em seu tratamento uma etapa de pré-tratamento, responsável pela remoção desses íons.

O sistema de tratamento de efluente coleta separadamente os efluentes alcalinos contendo cianeto, efluentes ácidos com cromo, efluentes alcalinos sem cianeto e efluentes ácidos sem cromo, como mostra a Figura 2. A coleta e transporte desses efluentes são realizados separadamente, principalmente, por motivos de segurança. A mistura de efluentes alcalinos contendo cianeto com efluentes ácidos podem gerar cianeto de hidrogênio (HCN), que nas condições ambientes é um gás muito tóxico. A redução do cromo hexavalente em cromo trivalente só ocorre na presença de redutores e em pH inferior a 3 (PONTE, 2002; BRAILE; CAVALCANTI, 1993). 


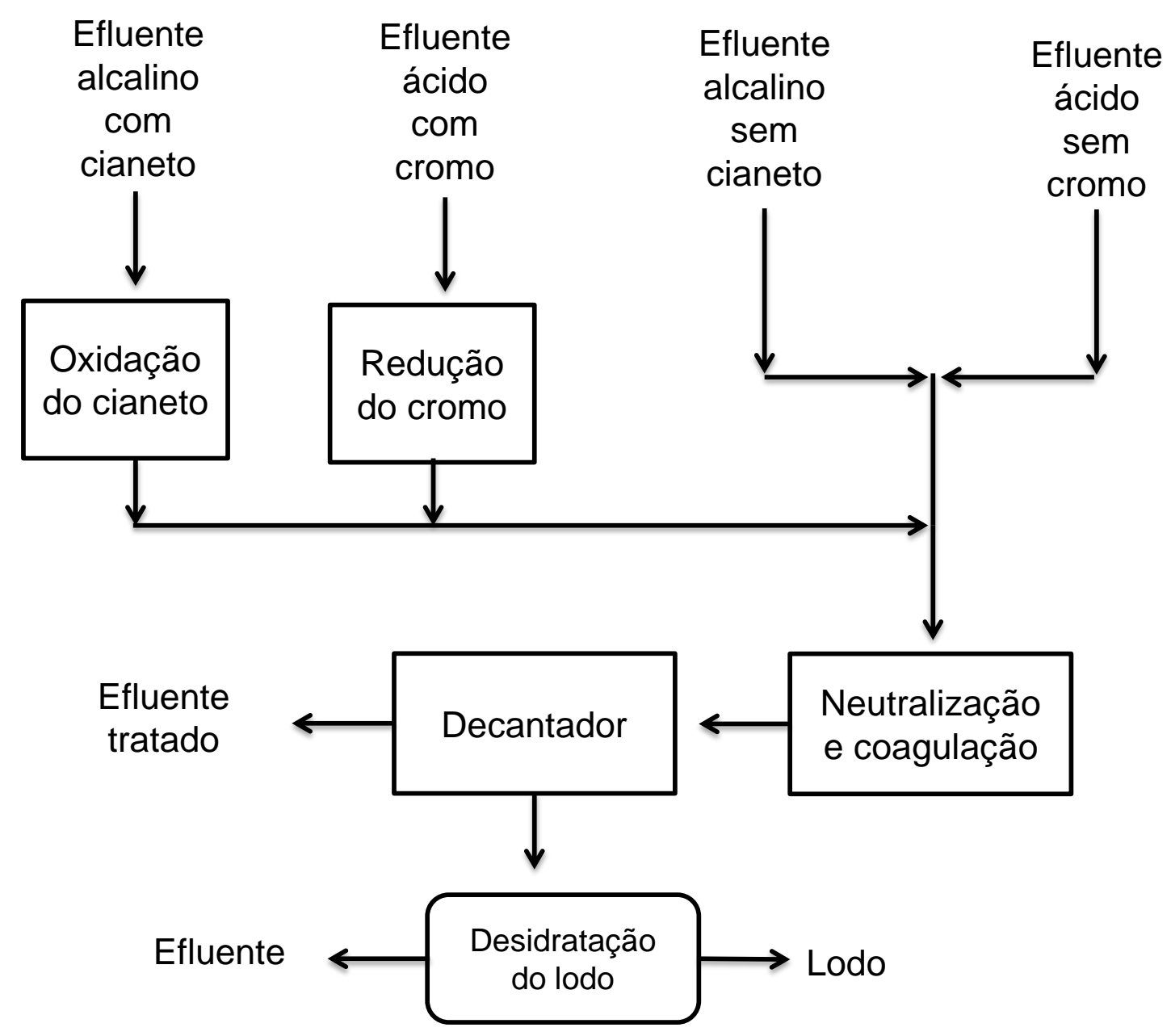

*Fonte: adaptado de Ponte, 2002.

Figura 2 - Tratamento de efluentes por batelada.

Para reduzir a toxicidade do efluentes contendo cianeto, normalmente, é utilizado um tratamento à base de gás cloro. Porém a cloração do cianeto pode resultar em compostos intermediários altamente tóxicos (cloretos de cianogênio), além da possibilidade de formação de organoclorados. Estes compostos em conjunto com o cloro residual proporcionam riscos ambientais, um dos motivos pelo qual é necessário o correto gerenciamento do resíduo gerado nesse processo (MARDER et al., 2003; BRAILE; CAVALCANTI, 1993).

A redução do cromo hexavalente em cromo trivalente só ocorre na presença de redutores (cloreto de ferro, sulfureto de sódio ou bissulfeto de sódio) e em pH inferior a 3. Devido sua toxicidade e suas condições específicas de tratamento, os sistemas de tratamento possuem uma etapa própria para a sua remoção do efluente (MAGALHÃES et al., 2005; BRAILE; CAVALCANTI, 1993). 
Os efluentes pré-tratados são encaminhados ao sistema de tratamento tradicional, que consiste no ajuste do $\mathrm{pH}$ a valores próximos a 8,5 pela adição de hidróxido de sódio ou hidróxido de cálcio, originando condições de baixa solubilidade onde os metais precipitam sob a forma de hidróxidos metálicos ou complexos diversos. Pela alta condição de supersaturação são formados sólidos coloidais que necessitam das etapas de coagulação/floculação para se separar da fase líquida. Esse material pelo seu peso molecular sofre o processo de sedimentação e posteriormente é removido e encaminhado à desidratação para reduzir a umidade, se tornando resíduo do processo de tratamento (NETO et al., 2008; MAGALHÃES et al., 2005).

O resíduo sólido de galvanoplastia também chamado de lodo de galvanoplastia ou borra galvânica, resultante do sistema de tratamento de efluentes contém, entre outros contaminantes, metais pesados. De acordo com Milanez et al. (2005), o lodo proveniente do tratamento de efluentes do processo de galvanoplastia tem recebido particular atenção devido à natureza de sua constituição baseada em metais alcalinos e de transição, principalmente cromo, níquel, cobre e zinco.

Apesar da precipitação com hidróxidos metálicos ser um método eficiente de tratamento de efluentes, tanto os ácidos quanto os metais presentes no lodo galvânico não são recuperados. Além disso, este sistema tem como desvantagens o elevado consumo de produtos químicos, tempos longos para decantação e grande quantidade de produtos utilizados no tratamento e o elevado custo para destinação ambientalmente correta do lodo galvânico (MANSUR et al., 2008; KURNIAWAN et al., 2006).

\subsection{Resíduos sólidos}

O aumento do crescimento populacional e das atividades industriais ocasionou como desvantagem um acréscimo na produção de resíduos sólidos, que podem ser divididos em duas grandes áreas, sendo elas, os resíduos urbanos (que contemplam também os serviços de saúde) e os resíduos industriais (CETESB, 1996).

Em 1996, a CETESB realizou um levantamento sobre a geração de resíduos sólidos no estado de São Paulo, e constatou que as indústrias geraram, 
por ano, mais de 500 mil toneladas de resíduos sólidos perigosos (Classe I), aproximadamente 20 milhões de toneladas de resíduos sólidos não inertes e mais de um milhão de toneladas de resíduos inertes. Dos resíduos perigosos, 53\% foram tratados, $31 \%$ armazenados e os $16 \%$ restantes foram depositados no solo, conforme apresentado na Figura 3 (CETESB, 2014 e CETESB, 1996).

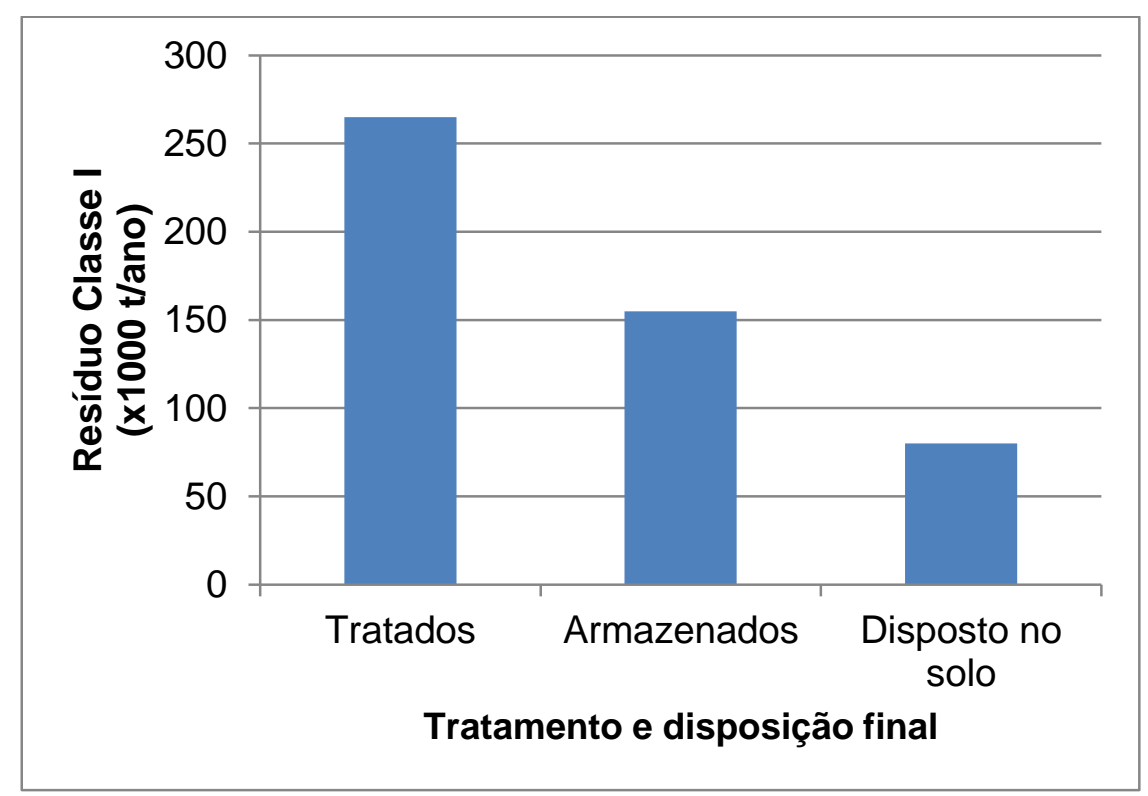

* Fonte: CETESB, 1996.

Figura 3 - Tratamento e disposição final de resíduos industriais (Classe I) no Estado de São Paulo

Os dados mais recentes sobre destinação de resíduos industriais são apresentados no estudo elaborado pela CETESB em 2014, utilizando 2010 como ano base. Os dados referem-se a uma amostragem não aleatória de 1.234 empreendimentos, considerando apenas unidades industriais com número de funcionários maior que 150, para empresas em geral, e número de funcionários maior que 70, para empresas químicas. As tipologias selecionadas foram (CETESB, 2014):

- Indústrias de preparação de couros e fabricação de artefatos de couro, artigos de viagem e calçados;

- Fabricação de coque, refino de petróleo, elaboração de combustíveis nucleares e produção de álcool;

- Fabricação de produtos químicos; 
- Metalurgia básica;

- Fabricação de produtos de metal, exceto máquinas e equipamentos;

- Fabricação de máquinas e equipamentos;

- Fabricação de máquinas para escritório e equipamentos de informática;

- Fabricação e montagem de veículos automotores, reboques e carrocerias;

- Fabricação de outros equipamentos de transporte;

- Galvanoplastias.

A distribuição percentual da geração de resíduos classe I em 2010, por tipologia industrial, é apresentada na Figura 4. Pode-se verificar que os grupos das indústrias Metalúrgicas e Químicas, somados, geraram 408.608,84 toneladas de resíduos perigosos, que corresponde a praticamente $60 \%$ do total.

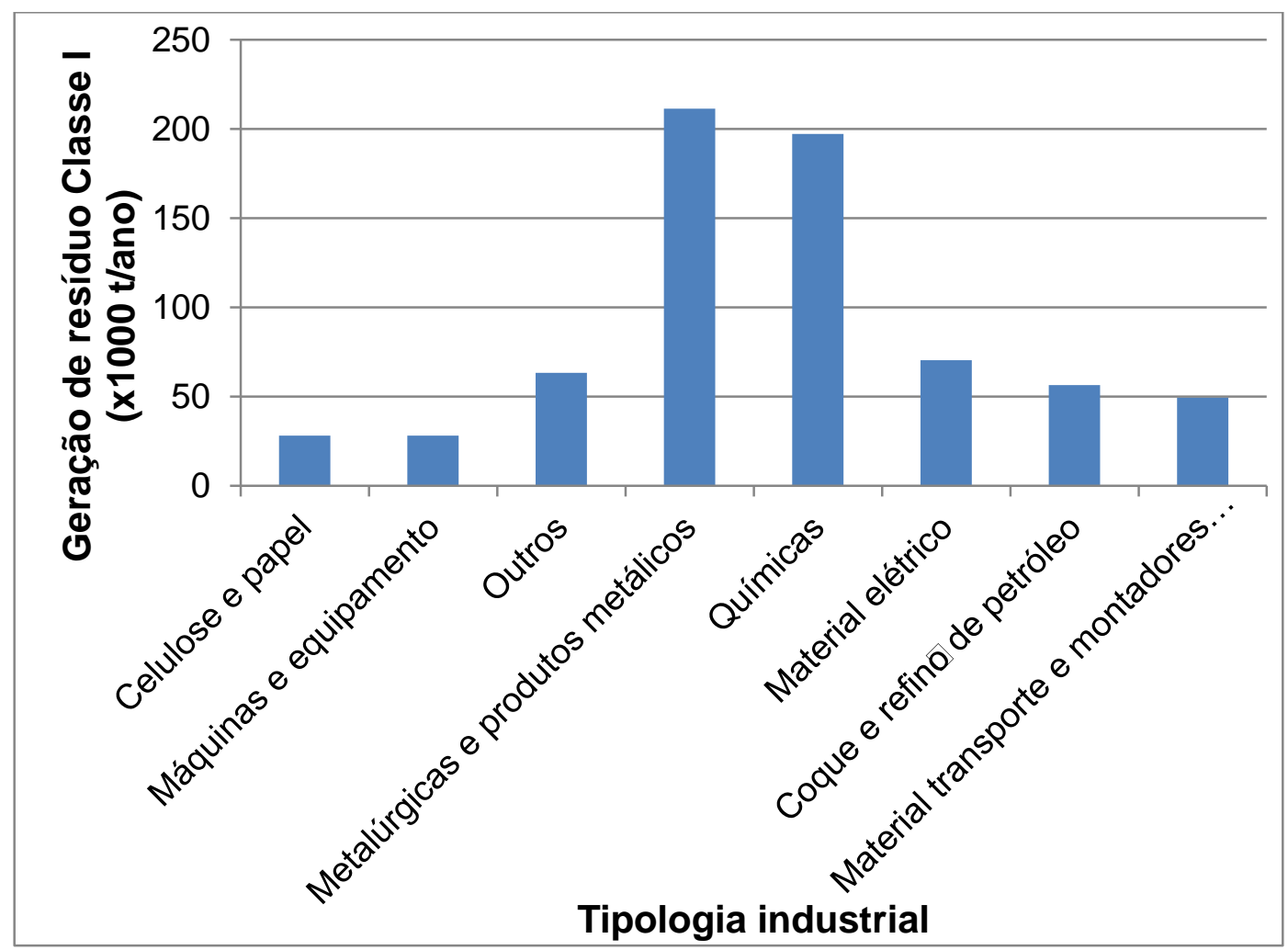

* Fonte: Adaptado de CETESB, 2014.

Figura 4 - Geração de resíduos classe I por tipologia industrial, em 2010.

A geração de resíduos sólidos industriais no estado de São Paulo em 2010 é composta por 704.498 toneladas de resíduos classe I e 95.135 .425 de resíduos classe II (Classe IIA e IIB), classificados segundo a ABNT NBR 
10.004/04. Embora solo contaminado não esteja contemplado no montante de resíduo classe I apresentado acima, o levantamento exibe a geração de 172.215 toneladas deste material, totalizando 876.713 toneladas de resíduos perigosos (CETESB, 2014.)

\subsubsection{Classificação dos resíduos sólidos - ABNT NBR 10.004/04}

A última versão desta norma é de 31 de maio de 2004 e teve vigência em novembro do mesmo ano. Foi elaborada no âmbito da ABNT para substituir a NBR 10004/87. Essa nova versão da norma classifica os resíduos sólidos para o gerenciamento independentemente de sua destinação final, ampliando a NBR 10.004/87 que focava a classificação dos resíduos sólidos apenas para sua disposição em aterros (SIMAS, 2007).

O objetivo desta norma é classificar os resíduos quanto aos seus potenciais riscos à saúde e ao meio ambiente, para que possam ser gerenciados adequadamente.

Para se classificar o resíduo se deve primeiramente compreender seu significado, que segundo NBR 10.004/04, é definido como:

\footnotetext{
Resíduos nos estados sólido e semi-sólido, que resultam de atividades de origem industrial, doméstica, hospitalar, comercial, agrícola, de serviços e de varrição. Ficam incluídos nesta definição os lodos provenientes de sistemas de tratamento de água, gerados em equipamentos e instalações de controle de poluição, bem como determinados líquidos cujas particularidades tornem inviável o seu lançamento na rede pública de esgotos ou corpos de água, ou exijam para isso soluções técnica e economicamente inviáveis em face à melhor tecnologia disponível. (p.1).
}

A NBR 10.004/04 classifica os resíduos em dois grupos: classe I Perigosos e classe II - Não perigosos, sendo que essa última é dividida em: classe II A - Não inertes e II B - Inertes, conforme pode ser observado na Figura 5. A antiga norma (10.004/87) classificava o não inerte como classe dois e inerte como classe três. Segundo Simas (2007) um aspecto importante refere-se ao laudo de classificação, pois a classificação de qualquer resíduo deve conter a indicação de sua origem com a identificação dos insumos e matérias primas, bem como a descrição do processo de segregação. 


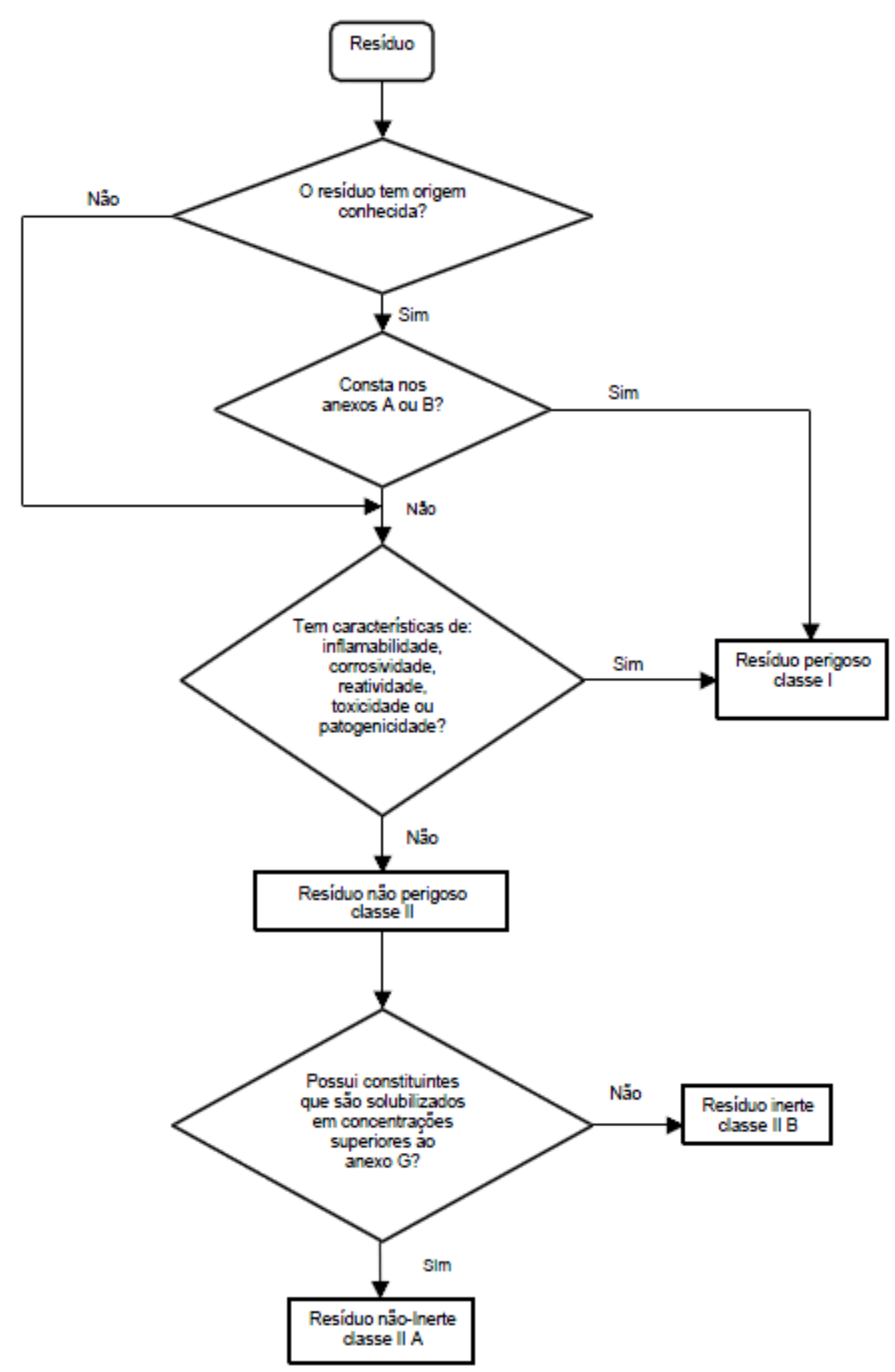

${ }^{*}$ Fonte: ABNT NBR 10.004/04.

Figura 5 - Fluxograma de classificação dos resíduos

Segundo a NBR 10.004/04, os resíduos sólidos são classificados em:

- Classe I - Perigosos: os resíduos são classificados como perigosos quando apresentam pelo menos uma das seguintes características: inflamabilidade, corrosividade, reatividade, toxicidade e patogenicidade, podendo apresentar riscos à saúde pública (mortalidade ou incidência de 
doenças) e ao meio ambiente, quando gerenciado de forma inadequada. Também pode ser considerado se constar nos anexos A ou B desta norma.

- Classe II A - Não inertes: classificam-se como não inertes quando não se enquadrarem como resíduos perigosos (Classe I) ou como inertes (Classe II B). Esses resíduos podem ter propriedades como: combustibilidade, biodegradabilidade ou solubilidade em água.

- Classe II B - Inertes: classificam-se como resíduos inertes os que, quando submetidos aos testes de solubilização da NBR 10.006, tenham seus constituintes de solubilização dentro dos padrões de potabilidade da água, excetuando-se aspecto, cor, turbidez, dureza e sabor, conforme anexo G. Segundo Simas (2007), podem ser citados como exemplo de resíduo classe II B vidros, tijolos, rochas e certas borrachas e plásticos que não são decompostos facilmente.

Os resíduos provenientes de processos industriais que constem nos anexos $A$ ou $B$ desta norma ou que apresentem em testes de lixiviação compostos ou elementos acima dos níveis fixados pela norma devem ser considerados como resíduo sólido perigoso. Esses elementos ou compostos que conferem periculosidade ao resíduo são: cromo, cádmio, chumbo, arsênio, bário, selênio, mercúrio, cianeto, prata, compostos organoclorados ou organofosforados e produtos contendo bifenil-policlorado (SIMAS, 2007).

\subsubsection{Resíduos Sólidos de Galvanoplastia}

Os resíduos gerados em processos industriais estão entre as mais importantes fontes de contaminação ambiental, principalmente os que usam ou produzem produtos químicos perigosos (SILVA et al., 2006).

Os resíduos sólidos são gerados na indústria, principalmente, como lodo das estações de tratamento de efluentes ou como subprodutos formados nos processos industriais (TEXEIRA, et al. apud SIMAS, 2007, p.10).

Os resíduos gerados em processos de galvanoplastia são constituídos pelos lodos de precipitação dos banhos de deposição metálica, do material retido nos sistemas de filtragem dos banhos, de soluções descartadas por 
contaminação e do lodo oriundo da estação de tratamento de efluente por processos físico-químicos (SIMAS, 2007).

O resíduo de galvanoplastia é o principal tipo resíduo gerado nestes processos. A sua composição está relacionada ao processo de galvanoplastia utilizado (cromação, zincagem, niquelação, folheados, etc.). Como as etapas utilizadas nestes processos são descontínuas, a constituição do lodo pode variar de acordo com as condições reais de operação (MAGALHÃES et al., 2005).

O lodo gerado em processos de galvanoplastia é constituído por compostos químicos, tais como o hidróxido, óxidos e sais metálicos. Quando o sistema de tratamento de efluentes utiliza na etapa de neutralização o hidróxido de cálcio, são geralmente encontrados no lodo galvânico o carbonato, sulfatos e fosfatos de cálcio (ROSSINI; BERNARDES, 2006).

O lodo galvânico é classificado pela ABNT NBR 10.004/04 como resíduo classe I (Perigoso), por constar no Anexo A desta norma. Segundo Magalhães et al. (2005), o carácter perigoso deste material está relacionado com a elevada concentração de espécies lixiviáveis, tais como metais pesados e/ou de transição, como cromo e níquel.

\subsubsection{Contaminação do solo}

As indústrias químicas, de metais não ferrosos e de curtumes, a siderurgia e os processos de galvanoplastia, decapagem e pintura, estão entre os setores industriais com maior potencial de geração de resíduos classe I. Ressalta-se que toda atividade industrial tem potencial de gerar resíduos classificados como perigoso pela legislação ambiental vigente (VALLE, 1995).

Os resíduos contendo metais pesados são considerados perigosos ao meio ambiente e à saúde humana, pois quando descartados erroneamente no solo podem se infiltrar e atingir lençóis freáticos, se inserindo no ecossistema (FERGUSSON apud SIMAS 2007, p.7).

A mobilidade e a retenção dos metais pesados no solo variam em função das suas propriedades, tais como $\mathrm{pH}$, capacidade de troca catiônica, massa de matéria orgânica, quantidade e tipo da fração de argila e competição iônica (CETESB, 2001). 
A elevada solubilidade dos metais pesados em ambientes aquáticos permite sua absorção por organismos vivos. Uma vez que inseridos na cadeia alimentar, podem ocasionar a sua bioacumulação nos seres vivos. A ingestão de metais pelos seres humanos em concentrações superiores à permitida podem ocasionar sérios problemas de saúde (KURNIAWAN et al., 2006).

Frequentemente, utiliza-se a expressão "metal pesado" para se designar metais classificados como poluentes do ar, água, solo, alimentos e forragens, envolvendo um grupo heterogêneo de metais, semi-metais e até mesmo não metais, como por exemplo, o selênio. Dos elementos denominados metais pesados, destacam-se o cobre, cromo, níquel, zinco, ferro, manganês, molibdênio, cobalto, alumínio, prata, cádmio, mercúrio e chumbo (CETESB, 2001).

O cromo é um elemento encontrado na natureza em rochas, plantas, solo e até mesmo em gases vulcânicos. As formas mais comuns encontradas no ambiente são o cromo (0), cromo (III), que é um nutriente essencial à saúde e ocorre naturalmente no meio ambiente, e cromo hexavalente, geralmente produzido em processos industriais (ATSDR, 2008; WHO, 1988).

A distribuição de compostos contendo cromo trivalente e hexavalente depende do potencial redox, do $\mathrm{pH}$, da presença de agentes redutores ou oxidantes, da cinética das reações, complexos insolúveis de cromo insolúvel e da concentração total de cromo. No solo, a forma predominante é de cromo trivalente (WHO 2003).

A exposição ao cromo ocorre pode ocorrer pela ingestão de alimentos e/ou água, ou inalação no local de trabalho. A ingestão de altos níveis de cromo (VI) pode resultar em anemia ou danos ao estômago ou intestinos. Respirar elevadas concentrações de crómio (VI) pode causar irritação na mucosa ou úlceras no nariz, corrimento nasal e dificuldades respiratórias, tais como asma, tosse, falta de ar. Comparativamente, necessita-se de concentrações maiores de cromo (III) para se obter o mesmo efeito à saúde da exposição ao (VI) (ATSDR, 2008).

\subsection{Alternativas para tratamento ou destinação de resíduos de galva- noplastia}

A legislação ambiental vigente atribui à fonte geradora à responsabilidade da gestão dos seus resíduos sólidos industriais, não havendo distinção sobre o 
porte e a qualidade gerada. Dessa forma, toda unidade industrial deveria ser capaz de reduzir, reutilizar, reciclar, tratar e dispor seus resíduos. As principais instalações licenciadas para manuseio de resíduos sólidos industriais classe I e II (IIA e IIB) no estado de São Paulo são apresentadas na Tabela 1 (CETESB, 2014).

\begin{tabular}{ccc}
$\begin{array}{c}\text { Tabela } 2 \\
\text { - Instalações licenciadas para manuseio de resíduos sólidos } \\
\text { industriais }\end{array}$ & Município \\
\hline Tipo de instalação & $\begin{array}{c}\text { Número de } \\
\text { unidades }\end{array}$ & \\
\hline $\begin{array}{c}\text { Armazenamento } \\
\text { temporário e } \\
\text { transbordo }\end{array}$ & 20 & $\begin{array}{c}\text { Americana, Arujá, Barueri, Campinas, Cotia, } \\
\text { Itaquaquecetuba, Limeira, Maua, Meridiano, } \\
\text { Rio Claro, São Paulo, Taboão da Serra, Vali- } \\
\text { nhos e Votuporanga. }\end{array}$
\end{tabular}

\begin{tabular}{ccc}
\hline $\begin{array}{c}\text { Coprocessamento } \\
\text { em fornos de } \\
\text { cimento }\end{array}$ & 3 & Salto de Pirapora, Cajati e Ribeirão Grande. \\
\hline $\begin{array}{c}\text { Incineração de } \\
\text { resíduos perigosos }\end{array}$ & 4 & $\begin{array}{c}\text { Cosmópolis, Guaratinguetá, Suzano e Ta- } \\
\text { boão da Serra. }\end{array}$ \\
\hline $\begin{array}{c}\text { Aterros para } \\
\text { resíduos perigosos }\end{array}$ & 4 & Caieiras, São José dos Campos, Sorocaba e \\
Tremembé.
\end{tabular}

* Fonte: CETESB, 2014.

O resíduo sólido de galvanoplastia é um dos problemas que mais afeta a atividade galvânica (CETESB, 2005). O lodo galvânico possui um teor de sólidos, segundo Magalhães et al. (2005), geralmente inferior $40 \%$ em massa. Esta 
elevada umidade apresenta fortes restrições para o transporte e a destinação deste material.

Tradicionalmente, a destinação mais utilizada para o lodo de galvanoplastia é a deposição em aterro. No entanto, este método apresenta desvantagens, tais como, a limitação de área disponível para expansão ou abertura de novos aterros, as restrições quanto a sua localização, as emissões de gases, composições de chorume, entre outros (MAGALHÃES, 2004).

A incineração, o coprocessamento em fornos de cimento e a disposição em aterros estão entre as principais formas de tratamento e/ou destinação de resíduos de galvanoplastia (CETESB, 2014). Nas últimas décadas, formas alternativas de destinações visando o reaproveitamento dos resíduos vêm sendo estudadas, tais como a incorporação de resíduos galvânicos em vidro de silicato ou em matrizes cerâmicas.

\subsubsection{Incineração}

A incineração é um processo de tratamento que utiliza a combustão controlada para degradação térmica dos resíduos, visando reduzir seu volume, sua toxicidade ou até mesmo, em alguns casos, eliminá-los (ROCCA, 1993).

O incinerador é formado por duas câmaras de combustão, sendo que na primeira os resíduos sólidos, semissólidos e líquidos são queimados a temperatura entre 800 e $1000^{\circ} \mathrm{C}$ com excesso de oxigênio, geralmente, entre $10 \%$ a $25 \%$, resultando na geração de gases, cinzas e escória. Na segunda câmara, os gases provenientes da combustão inicial são queimados a temperaturas da ordem de 1200 a $1400^{\circ} \mathrm{C}$. Os gases gerados são rapidamente resfriados a fim de evitar a recomposição das extensas cadeias orgânicas tóxicas, sendo em seguida tratados em lavadores de gases, ciclones ou precipitadores eletrostáticos, antes da sua emissão na atmosfera por meio da chaminé (SEBRAE/RJ, 2006).

Existem diversos tipos de fornos de incineração, sendo o mais comum o de grelha fixa, de leito móvel e o rotativo. No incinerador de grelha fixa, apresentando na Figura 6, os resíduos são dispostos sobre uma grelha e o ar é introduzido de modo a minimizar o arraste das cinzas. Geralmente, esse tipo de forno é constituído por duas câmaras, necessitando de combustível auxiliar para início e 
manutenção da queima. Para garantir o excesso de oxigênio, fundamental à completa combustão dos resíduos e gases, o fluxo de ar é executado por meio de um exaustor instalado antes da chaminé. As cinzas e escórias resultantes da queima se deslocam através dos orifícios da grelha para um recipiente, denominado cinzeiro, posteriormente removidas mecanicamente ou por via úmida (IBAM, 2001; ROCCA, 1993).

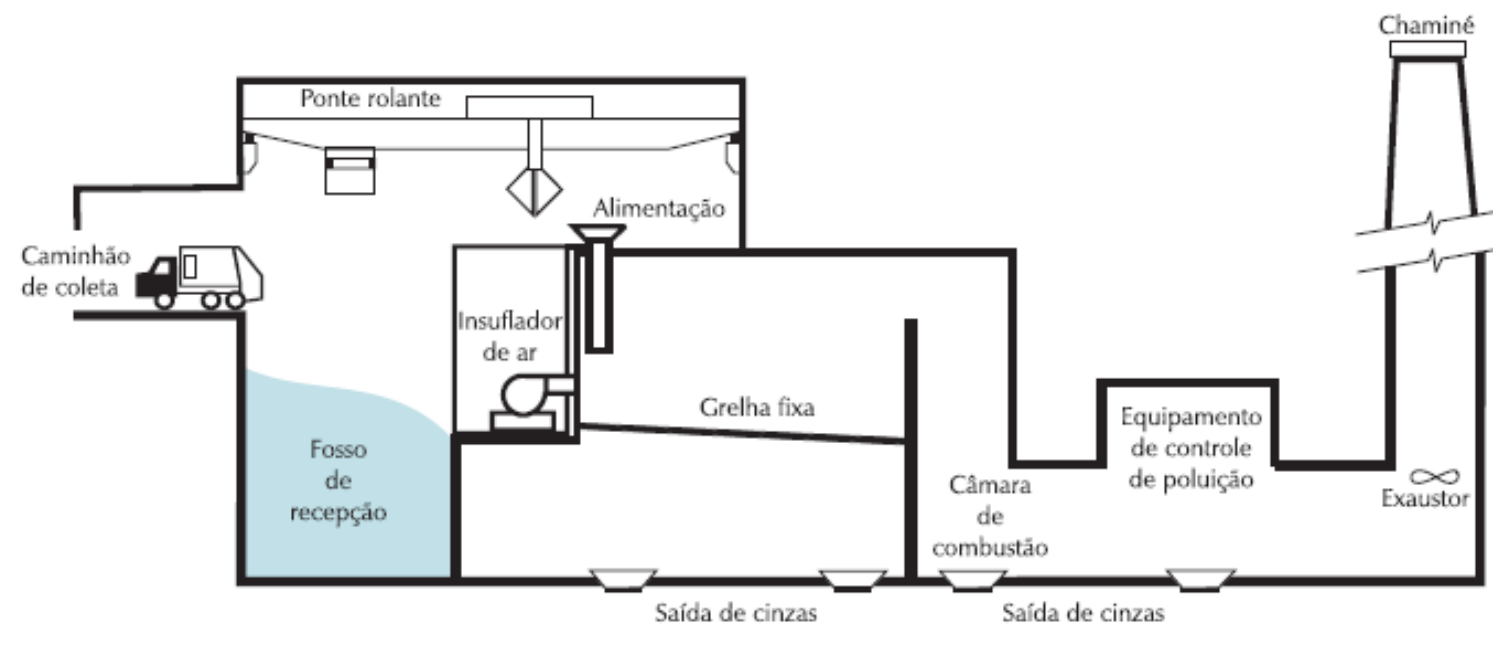

* Fonte: IBAM, 2001.

Figura 6 - Incinerador de grelha fixa.

Nos incineradores de leito móvel os resíduos são transportados, da porta de acesso até o fosso de remoção de cinzas e escórias, por meio de um leito móvel. O sistema de combustão é dividido em três seções, sendo a finalidade de a primeira secar os resíduos e da segunda e terceira efetuar a completa queima do material. As cinzas e escórias são descarregadas continuamente dentro de um fosso situado abaixo do forno, sendo posteriormente removidas mecanicamente ou por via úmida (IBAM, 2001).

Os incineradores de fornos rotativos são cilíndricos, revestidos internamente com material refratário, montados com uma pequena inclinação em relação ao eixo horizontal. Geralmente, possuem diâmetro da ordem de quatro metros e comprimento de até quatro vezes o diâmetro. Os resíduos são inseridos na extremidade superior e transportados até os queimadores por meio do movimento rotativo dos fornos. Este tipo de incinerador é o mais utilizado para tratamento de resíduos industriais Classe I. Os gases gerados são encaminhados para uma câmara secundária de queima, antes de serem encaminhados aos trocadores de 
calor e aos equipamentos de controle da poluição, conforme apresentado na Figura 7 (IBAM, 2001; ROCCA, 1993).

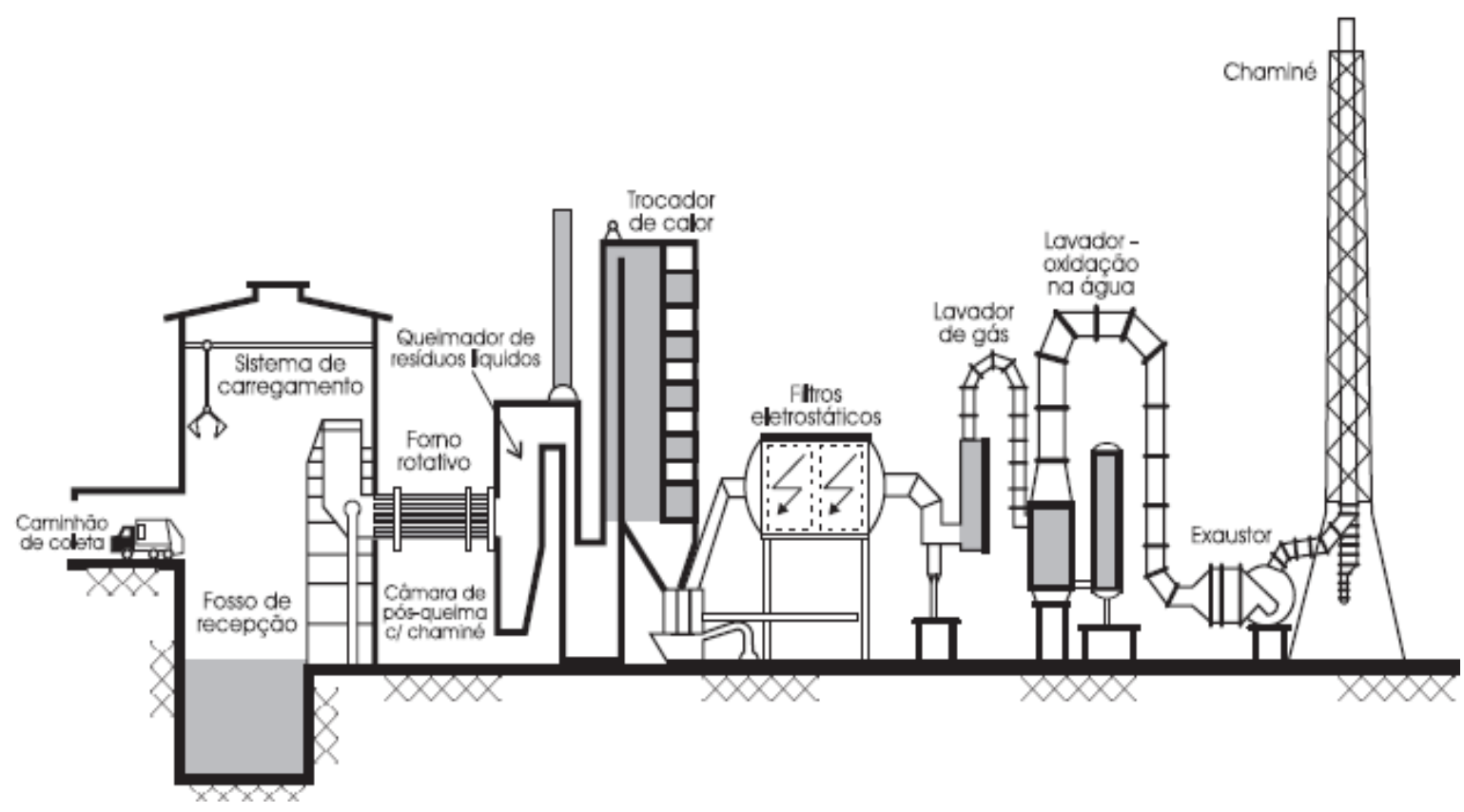

${ }^{*}$ Fonte: IBAM, 2001.

Figura 7 - Incinerador de fornos rotativos.

Para o tratamento de resíduos tóxicos contendo cloro, fósforo ou enxofre, além da necessidade de maior permanência dos gases na câmara de combustão, são precisos sofisticados sistemas de tratamento antes de sua emissão na atmosfera (IBAM, 2001).

Quando os resíduos são constituídos por metais é necessário realizar a correta disposição das cinzas após a incineração, pois a temperatura de queima não é suficiente para fundir e volatilizar os metais, permanecendo estes nas cinzas. Estas devem ter sua composição analisada para que seja determinado o melhor método de disposição, sendo geralmente o mais utilizado o aterro de resíduos industriais (SEBRAE/RJ, 2006 e IBAM, 2001).

A incineração possui como principais vantagens à redução do volume e da massa dos compostos, a possibilidade de tratamento de diversos tipos de resíduos e ser uma metodologia aceita pelos órgãos ambientais, desde que devidamente licenciados. No entanto, neste processo são geradas cinzas que devem ser devidamente destinadas de acordo com sua composição, emissões 
gasosas que devem ser controladas, além de possuir um elevado custo de operação (SEBRAE/RJ, 2006).

\subsubsection{Aterro industrial (classe I)}

O aterro é uma forma de disposição final que, desde que elaborado em conformidade com os critérios de engenharia e normas específicas, permitem um confinamento seguro dos resíduos em termos de proteção à saúde da população e poluição ambiental (ROCCA, 1993).

Atualmente, a disposição em aterro industrial é a alternativa mais usada para os resíduos industriais perigosos, pois, embora represente elevados custos à empresa, ainda é a destinação menos onerosa (MATTOS, 2011; CETESB, 2005; ROCCA, 1993).

Geralmente são destinados para aterros classe I resíduos, tais como, baterias de celulares e equipamentos eletrônicos, materiais com amianto, lodo de sistema de tratamento de efluentes, pirotécnicos, EPI contaminado, solo contaminado, entre outros (SEBRAE/RJ, 2006).

Os aterros para resíduos sólidos industriais se baseiam na abertura de valas no solo, onde o resíduo é depositado, compactado e posteriormente recoberto com terra. Estes aterros possuem uma cobertura metálica para impedir a infiltração de águas pluviais e um sistema de dupla impermeabilização para proteger o solo e a água subterrânea do contato com o percolado gerado que, ao ser captado pelo sistema de drenagem, é encaminhado para tratamento de efluentes (SIMAS, 2007, SEBRAE/RJ, 2006).

O manual de gerenciamento de resíduos sólidos elaborado pelo SEBRAE/RJ (2006) informa que um aterro industrial de conter as seguintes características:

- Impermeabilização com camada de argila e material polimérico de alta densidade;

- Sistema de coleta, transporte e tratamento do chorume gerado;

- Sistema de tratamento dos gases emanados;

- Monitoramento das águas subterrâneas. 
As condições mínimas exigíveis para projeto e operação de aterros de resíduos perigosos são apresentadas na norma ABNT NBR 10.157/87, que tem por objetivo proteger adequadamente os corpos hídricos superficiais e subterrâneos, os operadores destas instalações e a população lindeira.

Para assegurar que o projeto, instalação e operação de um aterro de resíduos perigosos sejam adequados, a ABNT NBR 10.157/87 estabelece exigências relativas à localização, segregação e análise de resíduos, monitoramento, inspeção, fechamento da instalação e treinamento de pessoal.

A escolha do local a ser utilizado para aterros de resíduos perigosos deve considerar a aceitação do projeto pela população lindeira, a minimização do impacto ambiental a ser causada pela instalação, a conformidade com o zoneamento da região e a possibilidade de ser utilizado por um longe período de tempo, necessitando do mínimo de obras para início da operação (ABNT NBR 10.157/87).

Todas as instalações que tratem, estoquem ou depositem resíduos perigosos devem possuir sistema de monitoramento de águas subterrâneas durante a sua vida útil, incluindo o tempo de pós-fechamento. Todo o líquido percolado deve ser coletado e tratado em uma estação de tratamento de efluentes, construída e operada de forma ao efluente tratado ser compatível aos padrões de lançamento do corpo hídrico receptor (ABNT NBR 10.157/87).

A camada impermeabilizante deve ser constituída por materiais com propriedades químicas compatíveis ao do resíduo, possuindo espessura e resistência que evitem rupturas. Deve ser instalada sobre toda a área destinada a disposição dos resíduos, de modo que chorume percolado não entre em contato com o solo natural (ABNT NBR 10.157/87).

Para encerramento da operação do aterro, devem-se adotar medidas de forma a minimizar a necessidade de manutenção futura e reduzir ou evitar a liberação de líquido percolado para os corpos hídricos adjacentes e/ou gases para a atmosfera (ABNT NBR 10.157/87).

A utilização de aterros industriais possui vantagens, tais como, a possibilidade de utilização para uma ampla variedade de resíduos e baixo custo quando comparado a outros meios de destinação e/ou tratamento, como incineração. No entanto, são consideradas desvantagens a grande área necessária para 
construção da instalação e a geração de um passivo que precisa ser monitorado continuamente, mesmo após sua desativação (SEBRAE/RJ, 2006).

A utilização de aterros para disposição de resíduos industriais, na Europa e nos EUA, é vista com restrições por não ser caracterizado como forma de tratamento. Após acidente com resíduos químicos como o de "Love Canal", nos EUA, as resistências para este tipo de destinação se intensificaram. Os locais para aterros, além de serem encarados como passivo ambiental de alto risco, uso dessa área é restrito para qualquer atividade futura (MATTOS, 2011; SIMAS 2007).

Os lodos gerados nos processos de tratamento de efluentes das galvanoplastias, geralmente, são destinados para aterros classe I ou condicionados ao solo. No entanto, esta forma descarte não é a mais adequada, devido à limitação de área disponível para expansão ou abertura de novos aterros, além das restrições quanto a sua localização, as emissões de gases, composições de chorume, entre outros (MAGALHÃES, 2004).

\subsubsection{Coprocessamento}

O coprocessamento consiste no reaproveitamento de resíduos nos processos de fabricação de cimento, utilizando-os como substituto parcial do combustível, reaproveitando o seu potencial energético, ou adicionando-os com a matéria-prima para a formação de clínquer (SEBRAE/RJ, 2006; RACT et al., 2003).

O coprocessamento é uma alternativa de baixo custo e frequentemente utilizado para tratamento térmico de uma grande variedade de resíduos, tais como borras oleosas, lodo de tratamento de efluentes, óleos e graxas, tintas e solventes, borrachas, solos contaminados, cinzas de fornos, entre outros (SEBRAE/RJ, 2006).

Os fornos de cimento rotativos e incineradores rotativos possuem características semelhantes, no entanto, o primeiro possui vantagens em relação ao tratamento dos resíduos, uma vez que na produção de clínquer o forno atinge temperaturas em torno de $2.000^{\circ} \mathrm{C}$. A incineração gera como subprodutos cinzas que, dependendo da origem dos resíduos, podem conter metais pesados. No 
coprocessamento em fornos de cimento os metais se agregam ao clínquer e são incorporados ao cimento, eliminando a necessidade de disposição em aterros (SEBRAE/RJ, 2006; RACT et al., 2003).

O aproveitamento do resíduo como fonte de energia e matéria prima na indústria cimenteira, o seu baixo custo quando comparado aos métodos similares e o fato de não gerar cinzas são as principais vantagens do coprocessamento. No entanto, seu uso é restrito pela Resolução CONAMA no 264 de 1999 aos resíduos domiciliares brutos, de serviços de saúde, radioativos, explosivos, organoclorados e agrotóxicos (SEBRAE/RJ, 2006).

\subsubsection{Aplicação em vidro e matriz cerâmica}

O processo de vitrificação simula o fenômeno natural de formação de vidro, onde os elementos tóxicos são absorvidos na matriz vítrea quimicamente estável. Em escala industrial, a vitrificação de resíduos perigosos tem sido aplicada ao tratamento de resíduos radioativos e inertização de cinzas de incineradores (SILVA; MELLO-CASTANHO, 2004).

O vidro possui características químicas e físico-químicas desejáveis para a inertização, tais como bom comportamento durante a fusão, homogeneidade, durabilidade e estabilidade em diferentes condições ambientais. Também apresenta uma estrutura amorfa aberta e pode facilmente ser incorporada com um grande número de elementos da tabela periódica. Estas características propiciam a utilização de matrizes vítreas para a incorporação de resíduos de galvanoplastia, que contém vários metais (SILVA; MELLO-CASTANHO, 2004).

Silva e Mello-Castanho (2004) realizaram a incorporação de resíduos galvânicos em vidro silicato. Utilizando técnicas de ajuste de formulação de composição, verificaram que os vidros obtidos com alta concentração de resíduos de galvanoplastia possuíam características interessantes, tais como, alta resistência a ataque hidrolítico, média resistência ao ataque alcalino e baixa resistência a ataque ácido, quando comparados ao vidro comum utilizando a mesma composição básica. Os vidros obtidos com concentrações de resíduos de galvanoplastia até $20 \%$ em massa apresentaram maior resistência ao ataque hidrolítico do que aqueles com as mesmas concentrações básicas. Vidros com até $40 \%$ em massa demostram boa resistência química. 
A incorporação de vários resíduos industriais em matrizes cerâmicas vem sendo estuda como uma técnica de baixo custo para a fixação de metais, visando à redução do volume dos resíduos a serem posteriormente descartados (MAGALHÃES et al., 2004).

O estudo realizado por Magalhães et al. (2004), avaliou o efeito de alguns parâmetros do processo de inertização de resíduo de galvanoplastia em cerâmica vermelha pelo mecanismo de macroencapsulação, tais como tempo de mistura, temperatura, tempo de calcinação, concentração de lodo adicionado, aspectos físicos da amostra, entre outros. Utilizando ferramentas de estatística para definir a relevância de cada variável experimental, observaram que a temperatura de queima, o grau de aglomeração imposto pela pressão do início da mistura e a quantidade de lodo adicionado na mistura desempenham papeis importantes no processo de inertização. Já o tempo de permanência à temperatura máxima de calcinação e o tempo de mistura durante a preparação das misturas são menos relevantes.

\subsection{Processos de remoção de metais do lodo de galvanoplastia}

Em função da crescente preocupação em relação ao esgotamento dos recursos naturais e desenvolvimento do consumo sustentável, pesquisas vêm sendo realizadas visando alternativas de tratamento de resíduos industriais que permitam sua reutilização ou reciclagem (ROSSINI; BERNARDES, 2006).

Tradicionalmente, a destinação mais utilizada para os resíduos de galvanoplastia são os aterros Classe I. Por este, vem crescendo o número de pesquisas focadas a recuperação dos metais presentes neste resíduo (KUCHAR et al., 2010). Entre os métodos de recuperação propostos na literatura, os mais relevantes a este estudo são apresentados a seguir.

\subsubsection{Recuperação de zinco, cobre e níquel por processos pirometalúrgico e hidrometalúrgico}

Entre as rotas existentes em literatura para recuperação de lodos de galvanoplastia, podem ser citados os processos hidrometalúrgico, pirometalúrgico e o de combinação de ambos. O primeiro está relacionado à lixiviação ácida da 
amostra e separação dos metais por precipitação seletiva. A principal característica da lixiviação ácida é baixa seletividade entre os metais valiosos e as impurezas. A lixiviação alcalina em meio amoniacal, seguido por extração com solvente, é mais seletivo. No entanto, a eficiência global na extração dos metais de interesse é menor. No processo pirometalúrgico, os elementos de interesse são introduzidos em um forno com um agente de sulfetação, transformando os metais alvos em sulfetos metálicos (ROSSINI; BERNARDES, 2006).

Outra opção é a combinação dos processos pirometalúrgicos e hidrometalúrgicos, recomendado para tratamento de resíduos de galvanoplastia contendo elevados teores de cobre, de níquel e de cobalto. O lodo é misturado a pirita (sulfureto de ferro) e introduzido em um forno com uma atmosfera oxidante, a fim de libertar o dióxido de enxofre, que reage os metais alvo, e os transformam em sulfetos, posteriormente processados em metalurgia básica (ROSSINI; BERNARDES, 2006).

Rossini e Bernardes (2006) elaboraram um sistema de tratamento por processo pirometalúrgicos e hidrometalúrgicos combinados, em escala de laboratório, para a recuperação seletiva de metais presentes no lodo galvânico. Os metais escolhidos foram o cobre, níquel, e o zinco e o agente de sulfatação utilizado foi a pirita, oriunda do processo de extração de carvão mineral. A particularidade deste trabalho é a utilização de dois resíduos perigosos como matéria-prima.

Primeiramente, o resíduo de galvanoplastia foi submetido a um processo de pré-lixiviação com solução de $\mathrm{HCl}$ a $25 \%$ para remoção do cálcio, visto que este elemento prejudica o processo de sulfetação dos metais de interesse. Em seguida, 3 gramas lodo galvânico lixiviado foram adicionados a pirita, em quantidades entre 0,3 e 3 gramas, e encaminhado para a calcinação na mufla a temperaturas entre $450^{\circ} \mathrm{C}$ e $700^{\circ} \mathrm{C}$, variando em $50^{\circ} \mathrm{C}$, para se obter o processo de sulfetação (ROSSINI; BERNARDES, 2006).

O melhor resultado do ponto de vista da recuperação dos metais e da viabilidade econômica do processo foi encontrado na proporção de 1:0,4 de lodo galvânico/pirita a $550^{\circ} \mathrm{C}$ de temperatura por $90 \mathrm{~min}$. Estas condições conduzem a uma recuperação de $60 \%$ de zinco, $50 \%$ de cobre e $43 \%$ de níquel (ROSSINI; BERNARDES, 2006). 


\subsubsection{Recuperação de cobre e níquel por lixiviação e eletrodeposição}

O trabalho realizado por Vegliò et al. (2002) estudou a viabilidade técnica de um processo de lixiviação acoplado com um de eletrodeposição para recuperar metais presentes em resíduos galvânicos e eletrônicos.

Inicialmente foram realizados dois testes de lixiviação, utilizando massas diferentes de resíduos de galvanoplastia. No primeiro foi adicionado um grama de lodo galvânico e $100 \mathrm{~mL}$ de uma solução de ácido sulfúrico $\left(\mathrm{H}_{2} \mathrm{SO}_{4}\right)$ em um balão volumétrico. Após a homogeneização ocorreu o ajuste da concentração para $10,00 \mathrm{~g} \cdot \mathrm{L}^{-1}$. O segundo experimento utilizou uma concentração de $100,00 \mathrm{~g} \cdot \mathrm{L}^{-1}$, sendo esta escolhida para o desenvolvimento do trabalho (VEGLIÒ et al., 2002).

Visando à otimização do processo de lixiviação, foram realizados ensaios alterando a concentração de ácido sulfúrico e a temperatura de reação (de $30^{\circ} \mathrm{C}$ a $90^{\circ} \mathrm{C}$, variando em $20^{\circ} \mathrm{C}$ ). Os resultados demonstram que a concentração mínima de ácido sulfúrico necessária para realizar a lixiviação do cobre e níquel é de 0,50 mol.L-1. No entanto, para obter uma eficiência próxima a 100\% é necessário o uso de $\mathrm{H}_{2} \mathrm{SO}_{4}$ em excesso (VEGLIÒ et al., 2002).

Após a lixiviação, as concentrações das amostras foram adequadas a $10,00 \mathrm{~g} \cdot \mathrm{L}^{-1}$ de cobre e de níquel, encaminhas para o processo de eletrodeposição. Para realizar a recuperação do cobre, o pH da amostra foi ajustado para um valor entre 2,00 a 2,20 a um potencial catódico relativamente constante $(2,40 \mathrm{~V}$ na célula) sob agitação constante de $200 \mathrm{rpm}$. Em seguida, as amostras foram encaminhadas para recuperação do níquel, elevando o pH da amostra para 10,50 a um potencial catódico relativamente constante $(2,70 \mathrm{~V}$ na célula) sob agitação constante de 200 rpm (VEGLIÒ et al., 2002).

Os resultados demonstram que o processo de lixiviação ácida combinado ao de eletrodeposição obteve uma eficiência entre 94-99\%, sendo utilizado para isso cerca de 2,13 $\mathrm{KWh} / \mathrm{Kg}$ para recuperação do cobre e 4,43 $\mathrm{KWh} / \mathrm{Kg}$ para o níquel (VEGLIÒ et al., 2002). 


\subsubsection{Recuperação do cromo de lodo de galvanoplastia por oxida- ção}

Silva et al. (2006) realizou a extração e recuperação do cromo oriundo do lodo da estação de tratamento de efluentes de uma galvanoplastia. Os primeiros testes foram realizados com ácido clorídrico $(\mathrm{HCl})$ em um tempo de reação de 24 horas. A utilização do $\mathrm{HCl}$ visa a redução dos custos de recuperação do cromo, visto que este ácido possui um valor de mercado inferior ao do ácido nítrico $\left(\mathrm{HNO}_{3}\right)$, empregado em literatura. Os resultados obtidos apresentam uma eficiência de até $99,60 \%$ de extração de cromo.

Visando reduzir os custos do processo, foram avaliados menores tempos de reação, de cinco e três horas. Como resultado, a eficiência de extração do cromo nestes experimentos se manteve elevada, variando de $87,50 \%$ em massa a $99,70 \%$ em massa, além de solubilizar praticamente todo o resíduo (SILVA et al., 2006).

Após cada teste de extração realizou-se a filtração da amostra, sendo que o resíduo foi submetido a ensaios de lixiviação para avaliação de riscos ambientais. Verificou-se que este material pode ser caracterizado como não perigoso (SILVA et al., 2006).

A oxidação é um dos processos existentes para recuperação do cromo oriundo de resíduos de galvanoplastia, pois oxida o cromo trivalente para cromo hexavalente, permitindo sua separação por filtração. Vários agentes oxidantes vêm sendo empregados em literatura, tais como o hipoclorito de sódio, ozônio e peróxido de hidrogénio (SILVA et al., 2006).

O hipoclorito de sódio é um agente oxidante eficiente para oxidação do cromo trivalente, no entanto, sua utilização pode apresentar alguns efeitos ambientais indesejáveis, pois a matéria orgânica do resíduo pode reagir com o cloro do hipoclorito e produzir compostos organoclorados prejudiciais à saúde. O ozono é um agente oxidante mais forte que o hipoclorito, mas o seu custo é consideravelmente maior, inviabilizando o seu uso (SILVA et al., 2006).

Silva et al. (2006) realizou a recuperação do cromo por meio do processo de oxidação com peróxido de hidrogênio, por ser uma técnica considerada simples e de baixo custo. Inicialmente, o pH da amostra foi ajustado a 10 mediante a adição deu uma solução de $\mathrm{NaOH}$. Para realizar a otimização do processo, 
foi avaliada a influência do tempo de oxidação (20, 40 e 60 minutos), da temperatura $\left(40^{\circ} \mathrm{C}, 50^{\circ} \mathrm{C}\right.$ e $\left.60^{\circ} \mathrm{C}\right)$ e da concentração de peróxido $\left(0,70 \mathrm{~mol} . \mathrm{L}^{-1}, 1,40\right.$ mol.L-1, e 2,10 mol.L-1 ${ }^{-1}$.

Como resultado, Silva et al. (2006) obteve a eficiência de recuperação de cromo de cerca de $92,50 \%$ em massa utilizando o tempo de 60 minutos, à temperatura de $60^{\circ} \mathrm{C}$ e a concentração de $\mathrm{H}_{2} \mathrm{O}_{2}$ de 2,10 mol.L-1. Alterando os parâmetros de processo, a mesma eficiência foi quantificada com o tempo de 40 minutos, temperatura de $60^{\circ} \mathrm{C}$ e 1,40 mol. $\mathrm{L}^{-1}$ de peróxido de hidrogênio, representando uma redução nos custos de recuperação.

James et al. (2000) realizou recuperação do cromo oriundo do lodo de uma indústria de galvanoplastia por meio do processo de oxidação com peróxido de hidrogênio. Primeiramente, 5 gramas de amostra foram adicionados a $50 \mathrm{~mL}$ de água destilada. $\mathrm{O} \mathrm{pH}$ da amostra foi ajustado a 8 pela a adição de uma solução de hidróxido de cálcio e, em seguida, acrescentou-se o peróxido de hidrogênio. Sob agitação, a amostra foi aquecida a $50^{\circ} \mathrm{C}$ por um tempo de 30 minutos, sendo o pH mantido acima de pH 8 pela adição de uma solução básica.

Para se determinar eficiência do processo de oxidação em função da concentração de peroxido de hidrogênio, o estudo avaliou 13 experimentos variando a sua concentração. Como resultado, foi obtida uma eficiência de remoção de cromo de $83 \%$ em massa para uma razão molar de $111,00 \mathrm{mmol}$ de $\mathrm{H}_{2} \mathrm{O}_{2}$ para 2,40 mmol de cromo trivalente (JAMES et al., 2000).

James et al. (2000) menciona que não foi possível atingir uma eficiência de oxidação de cromo de $100 \%$, pois alguns complexos de cromo trivalente, tais como $\mathrm{Cr}-\mathrm{O}-\mathrm{Cr}$ e/ou pontes $\mathrm{Cr}-\mathrm{OH}-\mathrm{Cr}$, são difíceis de oxidar com peróxido de hidrogênio, reduzindo a eficiência do processo de oxidação.

\subsubsection{Recuperação seletiva do cobre, zinco, níquel e cromo por pro- cesso de sulfetação e oxidação}

O trabalho realizado por Kuchar et al. (2010) estudou a recuperação seletiva do cobre, zinco, níquel e cromo presentes no lodo galvânico pelos processos sulfetação combinado ao de oxidação. 
Inicialmente, para remoção do cobre, o pH foi ajustado a 1,50 mediante a adição de ácido sulfúrico. Em seguida, realizou-se a adição do gás sulfídrico, utilizado para precipitar o cobre como sulfeto de cobre (CuS). Durante a sulfetação, o pH foi controlado em 1,50 por meio de uma solução $0,10 \mathrm{~mol} . \mathrm{L}^{-1}$ de hidróxido de sódio. Após realizar a filtração da amostra para remoção do sulfeto de cobre, o $\mathrm{pH}$ da amostra foi elevado a 4,50 para precipitar zinco como sulfeto de zinco $(Z n S)$, separado por filtração. A concentração de gás sulfídrico adicionado na amostra foi de 5.000 ppm, a uma vazão de $350 \mathrm{ml} \mathrm{min}^{-1}$. Como o agente de sulfetação é um gás, para sua introdução na amostra foi adicionado concomitantemente o gás nitrogênio, conforme pode ser observado na Figura 8.

A solução residual foi submetida a um tratamento de oxidação para converter o cromo trivalente em hexavalente, utilizando o peróxido de hidrogênio a uma concentração molar de 0,04 mol. $\mathrm{L}^{-1} \mathrm{em} \mathrm{pH}=10,00$ e temperatura de $60^{\circ} \mathrm{C}$. Depois do tratamento de oxidação, o pH foi ajustado para 9,50 e o cromo foi separado do óxido de níquel e recuperado sob a forma de dicromato $\left(\mathrm{Cr}_{2} \mathrm{O}_{7}{ }^{2-}\right)$, podendo ser reutilizado na indústria galvânico (KUCHAR et al., 2010).

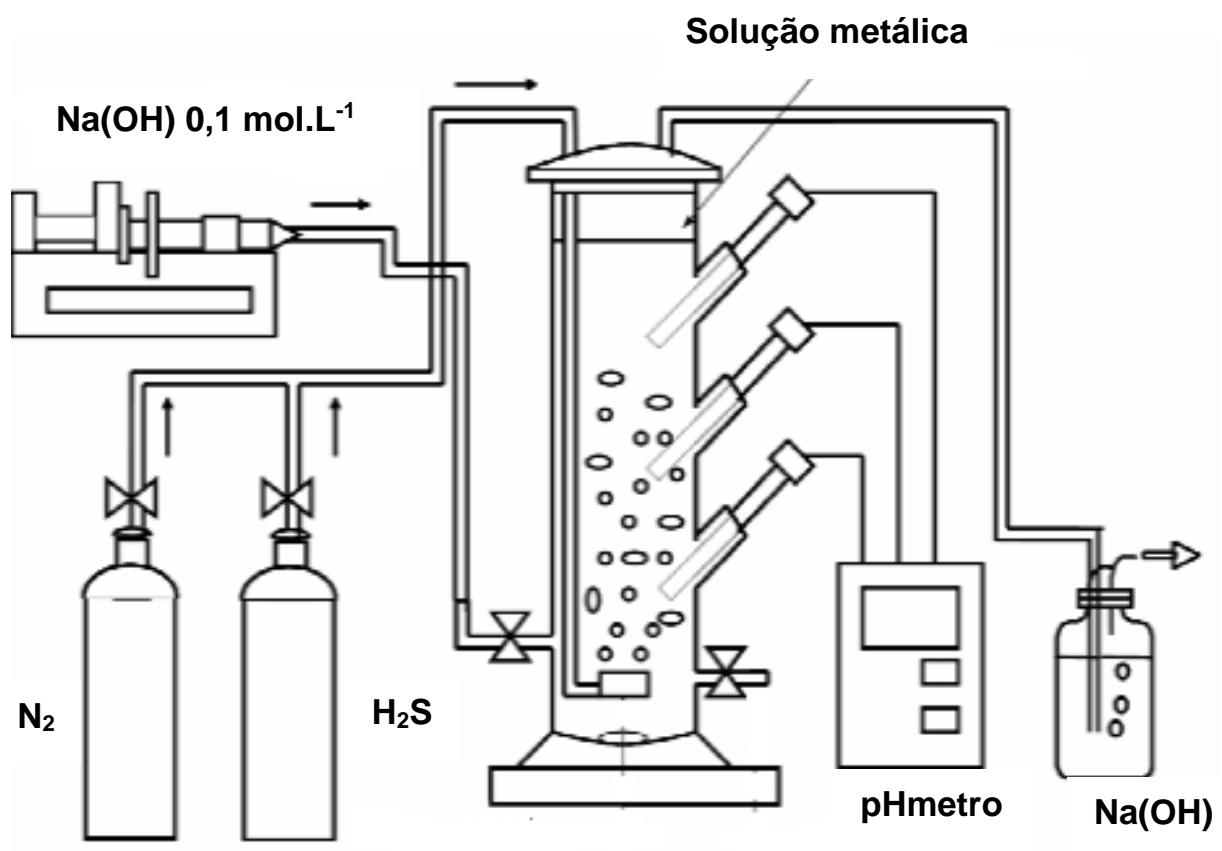

${ }^{*}$ Fonte: Kuchar et al., 2010

Figura 8 - Processo de sulfetação.

Para efetuar a remoção do cromo, primeiramente, foram realizados testes preliminares utilizando uma solução modelo de cloreto de cromo hidratado 
$\left(\mathrm{CrCl}_{3} \cdot 6 \mathrm{H}_{2} \mathrm{O}\right)$, com concentração de $100 \mathrm{mg} \cdot \mathrm{L}^{-1}$. O primeiro experimento foi realizado a pH 10,00 e tempo de reação de 60 minutos. A concentração de $\mathrm{H}_{2} \mathrm{O}_{2}$ na solução foi ajustada a $0,04 \mathrm{~mol} \cdot \mathrm{L}^{-1}$, que representou uma proporção equivalente de $\mathrm{H}_{2} \mathrm{O}_{2} / \mathrm{Cr}$ a cerca de 14,20 (KUCHAR et al., 2010).

Verificou-se que a razão de oxidação do cromo aumenta com a elevação da temperatura até $60^{\circ} \mathrm{C}$, sendo que a partir desta, não foram observados resultados significativos. Também foi avaliado o tempo de reação, obtendo-se uma razão de cerca de $62,00 \%$ nos primeiros 10 minutos e atingindo $78,00 \% \mathrm{com}$ o tempo de 120 minutos. Com base nestes resultados, o tempo e a temperatura para as experiências utilizando o resíduo de galvanoplastia foram ajustados para $60^{\circ} \mathrm{C}$ e 60 minutos, respectivamente (KUCHAR et al., 2010).

Este processo obteve como resultado a remoção de $96,60 \%$ de cobre em pH 1,50 e 91,50\% de zinco a pH 4,50. Em relação à etapa de oxidação do cromo, a maior razão quantificada foi de 59,00\%, inferior ao obtido nos testes preliminares com solução de cloreto de cromo. Também se realizou a remoção de 64,00\% de níquel (KUCHAR et al., 2010). 


\section{MATERIAIS E MÉTODOS}

O presente estudo envolveu a coleta do lodo de galvanoplastia, a caracterização por técnicas analítico-instrumentais e a remoção do cromo por dois processos, sendo que o primeiro envolve uma etapa de extração do cálcio e uma lixiviação ácida antes da remoção do cromo e o segundo visa exclusivamente à remoção deste elemento, conforme o fluxograma do procedimento experimental apresentado na Figura 9.

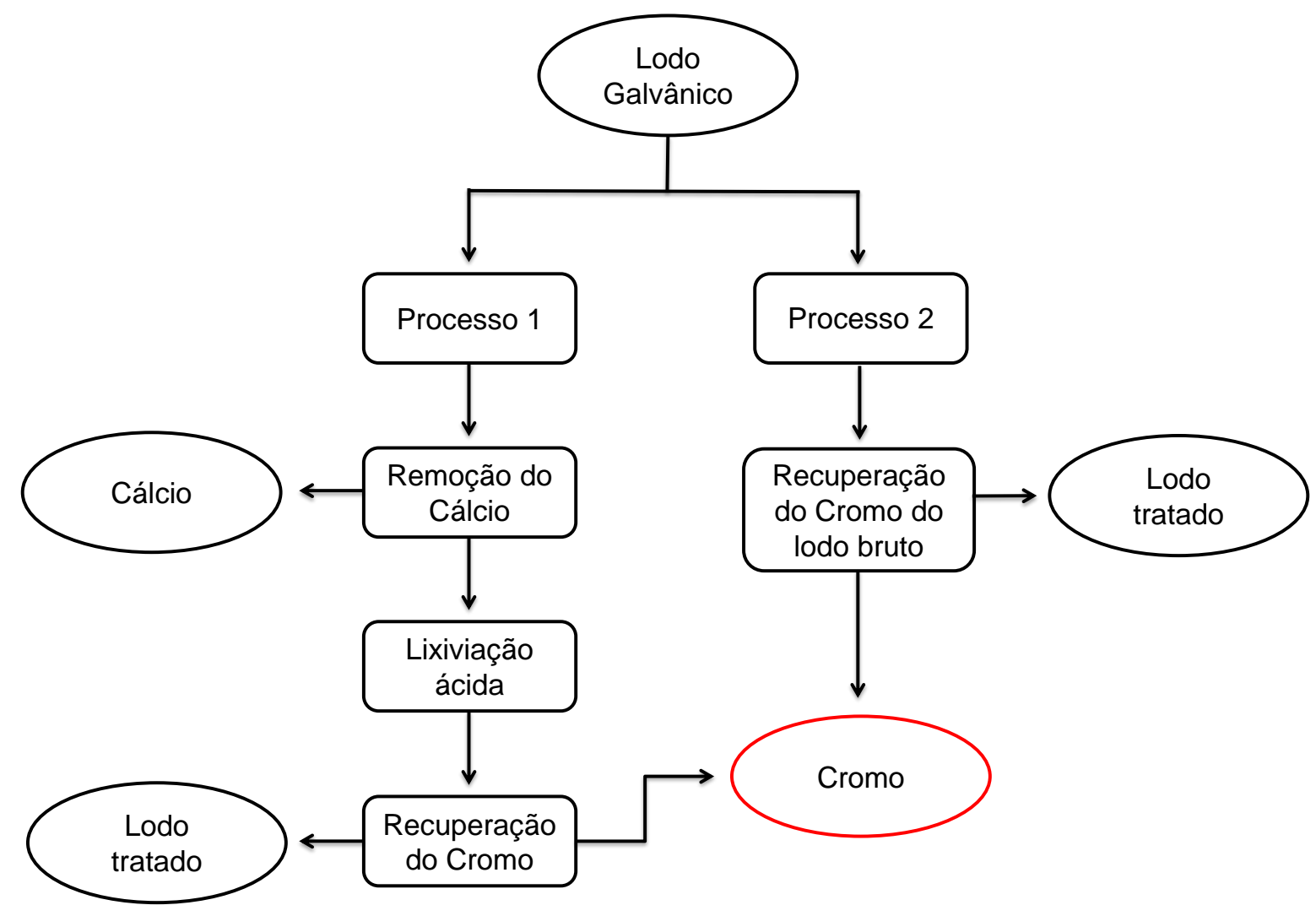

Figura 9 - Fluxograma do procedimento experimenta.

\subsection{Coleta do resíduo sólido galvânico}

Selecionou-se uma empresa fornecedora de resíduo de galvanoplastia, localizada na zona leste no município de São Paulo, que teve sua identidade preservada devido à solicitação da mesma.

A coleta do lodo de galvanoplastia, oriundo da estação de tratamento de efluentes por precipitação química com hidróxido de cálcio, foi realizada diretamente dos tambores de armazenamento (Figura 10) da empresa fornecedora utilizando um amostrador, segundo as diretrizes da ABNT NBR 
10.007/04 de amostragem de resíduo sólidos, retirando aproximadamente um quilograma de material. Para obter uma amostra representativa, efetuou-se o processo citado em cinco tambores, totalizando cinco quilogramas de lodo galvânico. O material foi armazenado em frascos plásticos com identificação por rotulagem, para posteriormente ser caracterizado.

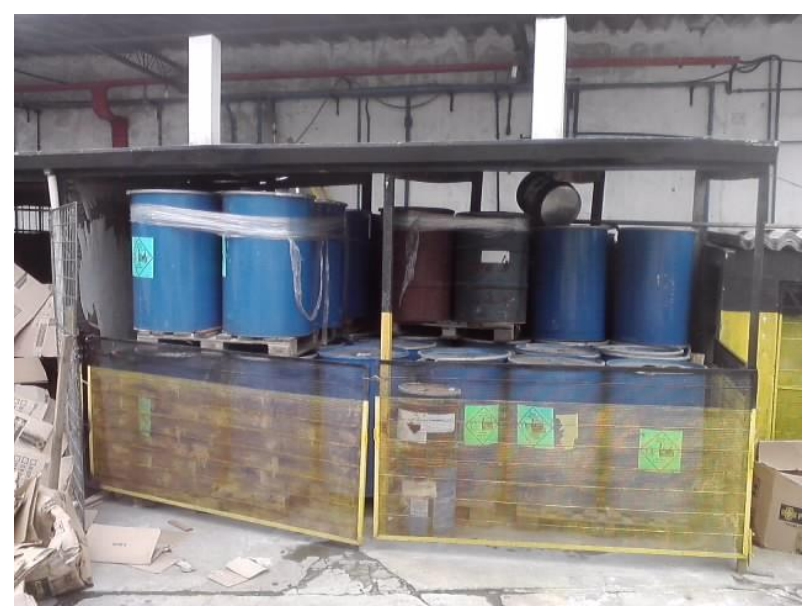

Figura 10 - Tambores de acondicionamento de lodo galvânico na empresa em estudo.

\subsection{Preparação e caracterização da amostra}

\subsubsection{Preparação da amostra de lodo galvânico}

Encaminhou-se o resíduo de galvanoplastia à estufa com temperatura de $\pm 110^{\circ} \mathrm{C}$ durante 24 horas para a remoção da fração líquida, como mostra a Figura 11. Essa secagem se deve a elevada porcentagem de umidade presente neste material, que segundo Magalhães (2005), é geralmente superior 60\% em massa.

Após a secagem na estufa, moeu-se o material no almofariz de ágata, para reduzir sua granulometria. Em seguida se realizou o quarteamento do material segundo a norma ABNT NBR 10.007/04 para separar as amostras que foram encaminhadas para as análises químicas. Este procedimento é necessário para garantir a homogeneização da amostra e, consequentemente, para viabilizar as análises realizadas, uma vez que o lodo de galvanoplastia é um resíduo muito heterogêneo e sua coleta ocorreu em tambores diferentes. 


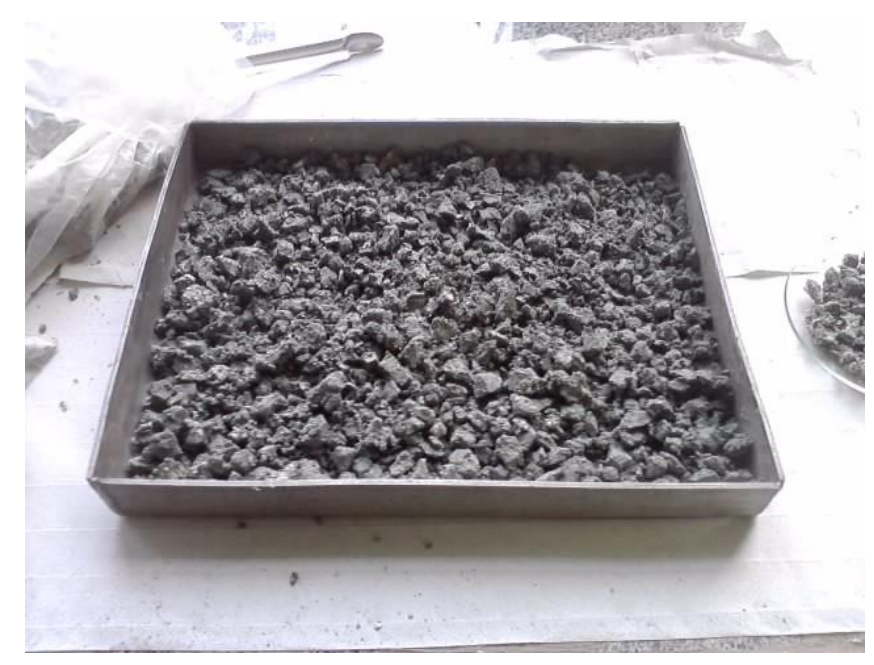

Figura 11 - Secagem do lodo de galvanoplastia na estufa a $\pm 100 \stackrel{\circ}{\circ}$ por 24 horas.

\subsubsection{Caracterização do Lodo Galvânico}

A caracterização do resíduo sólido galvânico foi realizada pelas análises de espectrometria de fluorescência de raios $X$, espectrometria de emissão óptica de plasma de argônio e absorção gasosa.

A fluorescência de raios $X$ por energia dispersiva (FRX-EDX) é um método que utiliza um feixe primário (feixe de raios $X$ ) para excitar substâncias. Cada elemento emite uma radiação secundária (fluorescente) característica, que é detectada pelo equipamento (SKOOG et al., 1998). A composição química do lodo de galvanoplastia foi obtida em porcentagens semiquantitativas por um espectrômetro marca Shimadzu, modelo EDX 900HS.

A análise de espectrometria de emissão ótica com plasma de argônio (Inductively Coupled Plasma - Optical Emission Spectrometry, ICP-OES) tem por objetivo identificar e quantificar os elementos presentes na amostra. A técnica baseia-se na emissão de fótons a partir de átomos e íons excitados por uma descarga de radiofrequência. As amostras líquidas e gasosas podem ser injetadas diretamente no instrumento, mas as sólidas devem ser digeridas com ácido para ficarem em solução, que é convertida em aerossol e dirigida para dentro do plasma de argônio, que possui uma temperatura de cerca de $10.000 \mathrm{~K}$, sendo rapidamente vaporizado. Os íons metálicos são liberados como átomos no estado gasoso. Além disso, as colisões entre os átomos dentro do plasma transmitem energia adicional, os promovendo ao estado excitado. Este processo gera uma 
energia tal que resulta emissão de um fóton, que têm energias características para cada átomo ou íon. Assim, o comprimento de onda dos fotões pode ser utilizado para determinar os elementos a partir dos quais são originados. O número total de fotões é diretamente proporcional à concentração do elemento presente da amostra (MEYERS, 2000).

A absorção gasosa ocorre em duas etapas, sendo a primeira a extração dos gases do material perante atmosfera de oxigênio, seguido pela identificação analítica utilizando um cromatógrafo com detector infravermelho (PRADO et al., 2002). Os teores de carbono e enxofre foram medidos em um cromatógrafo marca LECO, modelo CS 400. Segundo Moura et al. (2013) este equipamento utiliza o forno de indução HF 400 e mede, por absorção de infravermelho, o carbono como dióxido de carbono $\left(\mathrm{CO}_{2}\right)$ e enxofre como dióxido de enxofre $\left(\mathrm{SO}_{2}\right)$.

As análises de ICP-OES e FRX-EDX foram realizadas após cada etapa do processo de recuperação, possibilitando a avaliar a eficiência da remoção do cálcio e da recuperação do cromo.

$\mathrm{Na}$ etapa de extração do cálcio, realizaram-se análises de FRX-EDX no material sólido removido por meio da filtração e ICP-OES na amostra filtrada (efluente), possibilitando determinar qual a porcentagem de cálcio que permanece na amostra líquida, posteriormente encaminhada para a remoção do cromo. Estas análises também são essenciais para determinar se este processo, além de remover o cálcio, está precipitando outros elementos, principalmente os metais pesados, que contaminariam o material filtrado e prejudicariam a etapa de oxidação, caso o cromo seja retido nesta etapa.

Após a oxidação do cromo, realizaram-se análises de ICP-OES na amostra filtrada, para se determinar a eficiência do sistema de recuperação do cromo.

\subsection{Remoção do cálcio e cromo}

Realizou-se, neste trabalho, dois processos para efetuar a remoção do cromo, conforme o fluxograma do procedimento experimental apresentado na Figura 11. O primeiro visa à remoção do cálcio e do cromo, por meio da utilização do ácido cítrico, para extração do cálcio, seguido pela lixiviação com água régia e 
oxidação com peróxido de hidrogênio para separação do cromo, com base nos estudos realizados por Kuchar et al. (2010) e Silva et al. (2006).

O segundo processo consiste exclusivamente na remoção do cromo, conforme mostrado na Figura 11. Neste processo se realizou a oxidação do cromo com o lodo bruto, isto é, sem efetuar a lixiviação. Como a proposta era utilizar o lodo sem tratamento prévio, visando comparar os resultados com o obtido pelo método apresentado em literatura, não se efetuou a remoção do cálcio, visto que para isso seria necessário à utilização de ácido cítrico e, consequentemente, a lixiviação para remoção do cromo.

\subsubsection{Remoção do cálcio e recuperação do cromo}

\subsubsection{Remoção do cálcio}

Realiza-se o processo de extração do ácido cítrico por meio da utilização do hidróxido de cálcio, devido à reação do cálcio com ácido cítrico presente nas frutas, conforme apresentado na equação 1, resultando na formação do citrato de cálcio (MALAGONI et al, 2009). A utilização deste método se deve ao fato do citrato de cálcio ser um produto de baixa solubilidade $\left(0,96 \mathrm{~g} \cdot \mathrm{L}^{-1}\right.$, segundo LABSYNTH (2012)).

$$
2 \mathrm{H}_{3} \mathrm{C}_{6} \mathrm{H}_{5} \mathrm{O}_{7}+3 \mathrm{Ca}(\mathrm{OH})_{2} \longrightarrow \mathrm{Ca}_{3}\left(\mathrm{C}_{6} \mathrm{H}_{5} \mathrm{O}_{7}\right)_{2}+6 \mathrm{H}_{2} \mathrm{O}
$$

Utilizou-se o ácido cítrico para remover o cálcio presente no lodo galvânico, com objetivo de formar o citrato de cálcio removido por filtração. O preço médio de mercado do ácido cítrico foi o fator preponderante na escolha deste insumo químico, com valor de $\mathrm{R} \$ 19,44$ por quilograma de produto.

O cálcio presente no lodo de galvanoplastia é oriundo da etapa de precipitação metálica utilizada nas estações de tratamento de efluentes. Este elemento está presente no resíduo de galvanoplastia como óxidos e sais de cálcio insolúvel. No entanto, a presença destes óxidos pode prejudicar o processo de oxidação do cromo, pois os cromatos $\left(\mathrm{CrO}_{4}{ }^{2-}\right)$ podem reagir com estes óxidos de cálcio, formando cromato de cálcio anidro e outros sais de cálcio insolúveis 
(JAMES et al., 2000). Visando melhorar a eficiência do processo de oxidação do cromo, primeiramente, realizou-se uma etapa para remoção do cálcio.

O processo se iniciou com $750 \mathrm{~mL}$ de água destilada em um béquer de 1 litro. Adicionou-se lentamente o ácido cítrico sob a rotação de $300 \mathrm{rpm}$, utilizando um agitador mecânico da marca IKA (modelo RW 20 digital). Manteve-se a solução em agitação por 20 minutos para garantir a homogeneização total da amostra.

Calculou-se a massa de ácido cítrico utilizada com base na relação molecular apresentada na equação 1. Para garantir a dissolução da amostra se utilizou concentrações de ácido cítrico em excesso, sendo as razões mássicas de ácido cítrico/hidróxido de cálcio empregadas na realização do trabalho: 2,5, 5,5 e 8.

Adicionou-se o lodo de galvanoplastia vagarosamente à solução de ácido cítrico, sob a agitação de 500 rpm. Realizada a inserção do resíduo, manteve-se a solução em agitação por 30 minutos a $700 \mathrm{rpm}$ para propiciar a reação entre o cálcio e o ácido cítrico, e manter a solução de ácido cítrico e lodo homogênea (Figura 12).

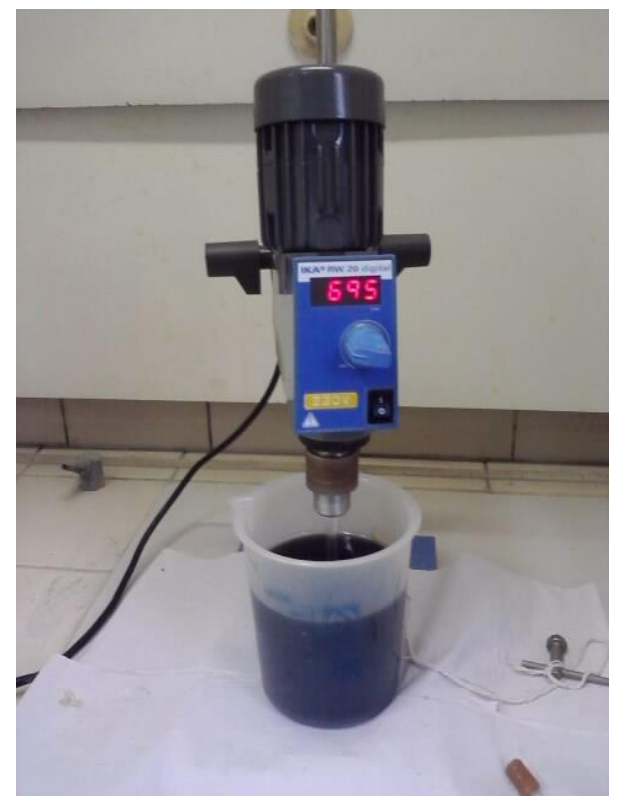

Figura 12 - Homogeneização da amostra a $700 \mathrm{rpm}$ para propiciar a reação entre o cálcio e o ácido cítrico.

A amostra homogeneizada foi submetida ao processo de filtração utilizando filtro de papel quantitativo Framex $389^{3}$ de filtração lenta (1500 segundos). O funil de vidro foi acoplado em um frasco de Erlenmeyer para armazenamento da amostra líquida, conforme ilustrado nas Figuras 13 e 14. 

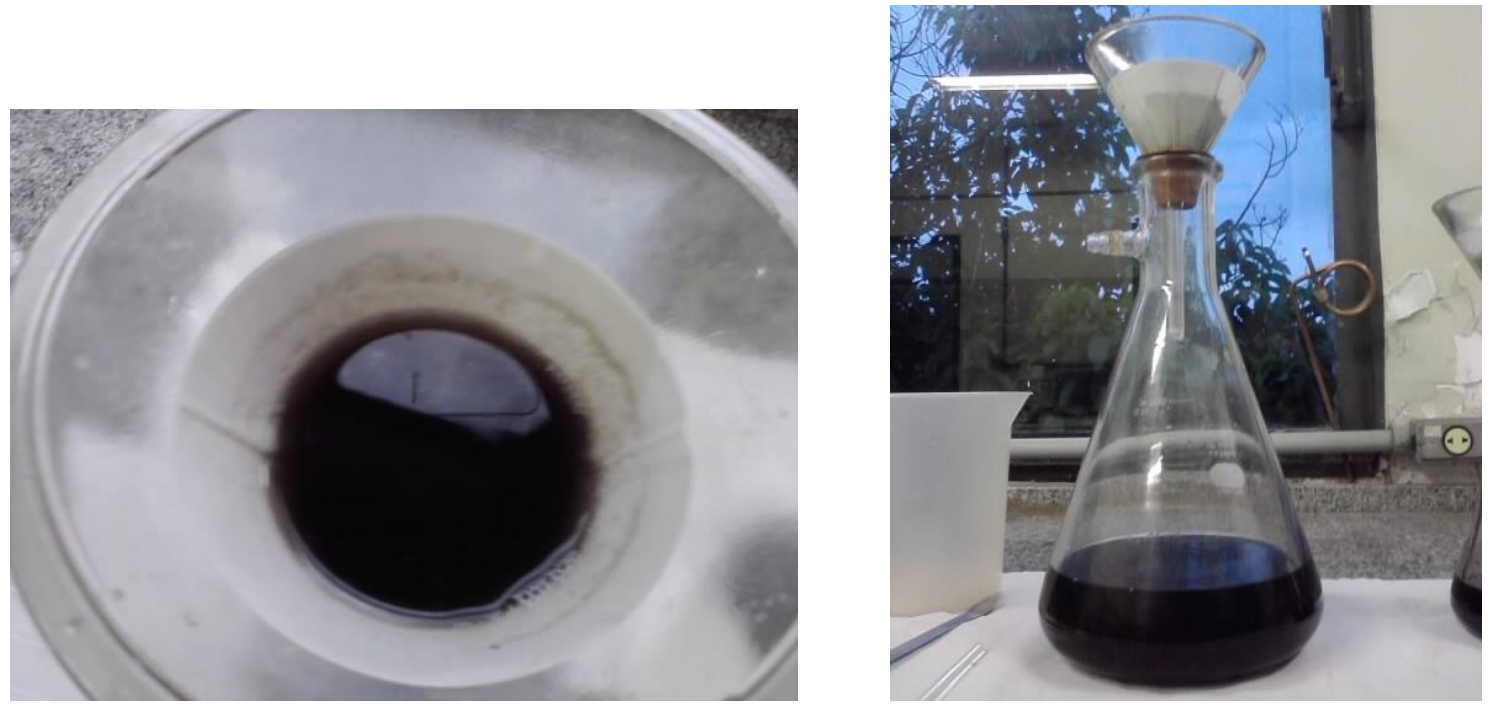

Figuras 13 e 14 - Processo utilizado para filtração das amostras.

A amostra contida no papel de filtro foi encaminhada à estufa de secagem e esterilização da marca Fanem (modelo 515) a uma temperatura de $110^{\circ} \mathrm{C}$ por 24 horas visando a secagem. Em seguida, a amostra seca foi conduzida à um forno mufla da marca Quimis (modelo Q318M24) a 150ㄷ com aumento gradativo da temperatura até $800^{\circ} \mathrm{C}$. As condições adotadas na etapa de calcinação da amostra foi de $150^{\circ} \mathrm{C}$ a $350^{\circ} \mathrm{C}$ com elevação da temperatura em $100^{\circ} \mathrm{C}$ por hora, ajustou-se a temperatura a $500^{\circ} \mathrm{C}$ durante uma hora e, por fim, se manteve $800^{\circ} \mathrm{C}$ por três horas.

Para realizar a remoção do papel filtro das amostras foram realizados ensaios preliminares no forno mufla Quimis (modelo Q318M24) com variações de temperatura e tempo. Percebeu-se que utilizando temperaturas inferiores a $800^{\circ} \mathrm{C}$ em tempos menores que 3 horas ocorria à formação de cinzas oriundas do papel filtro, motivo pelo qual foram adotadas as condições de calcinação mencionadas acima. As amostras calcinadas foram encaminhadas para determinação da composição química por meio da técnica de fluorescência de raios $\mathrm{X}$ por energia dispersiva.

\subsubsection{Recuperação do cromo por processo de lixiviação}

O Processo de recuperação de cromo iniciou-se com a lixiviação ácida dos metais, apresentado na Figura 15. No estudo elaborado por Silva et al. (2006), para dissolução de 1 grama de lodo galvânico utilizou-se $5 \mathrm{~mL}$ de ácido nítrico. No 
entanto, o ácido nítrico possui um elevado custo de mercado, fato este que prejudica economicamente a utilização deste processo de recuperação do cromo em larga escala.

A utilização do ácido clorídrico como agente de extração é uma alternativa para redução dos custos do processo de remoção do cromo, por possuir um menor custo comercial quando comparado ao ácido nítrico.

Para realizar a lixiviação ácida utilizou-se três soluções para avaliar a que possui a melhor eficiência, sendo elas a água régia (mistura de $\mathrm{HNO}_{3}$ e $\mathrm{HCl}$ na proporção $1 / 3$, respectivamente), água régia invertida $\left(\mathrm{HNO}_{3} \mathrm{e} \mathrm{HCl}\right.$ na proporção 3/1, respectivamente) e ácido clorídrico puro.

Após a dissolução ácida das amostras, estas foram envidas para a etapa de filtração, realizada por meio de um funil de vidro com filtro de pape quantitativo Faixa Azul de filtração lenta (porosidade de 2 micras), acoplado em um frasco de Erlenmeyer para armazenamento da amostra líquida.

O papel filtro contendo a amostra precipitada foi encaminhado à estufa de secagem e esterilização Fanem (modelo 515) a $110 \stackrel{\circ}{\mathrm{C}}$ por 24 horas para realizar a sua secagem, com objetivo de otimizar o processo de calcinação. Conduziu-se o material removido da estufa ao forno mufla Quimis (modelo Q318M24) a $150 \stackrel{\circ}{\circ}$ com elevação gradativa da temperatura até $800{ }^{\circ} \mathrm{C}$.

Desenvolveram-se os processos de extração com água régia e a água regia invertida de forma semelhante. Primeiramente, como apresentado em fluxograma na Figura 15, transferiu-se 25 gramas de lodo de galvanoplastia para um becker de vidro e, adotando a proporção de $6,4 \mathrm{~mL}$ de ácido para um grama de lodo, adicionou-se na amostra dissolvida com água régia, $120 \mathrm{~mL}$ de ácido clorídrico e $40 \mathrm{~mL}$ de ácido nítrico. No entanto, como não ocorreu à solubilização total da amostra, acrescentou-se mais $60 \mathrm{~mL}$ de ácido clorídrico e $20 \mathrm{~mL}$ de ácido nítrico. Repetiu-se este procedimento até atingir a proporção de $16 \mathrm{~mL}$ de ácido para um grama de lodo galvânico. A água régia invertida utiliza a mesma quantidade de ácido, mas nas proporções inversas $(100 \mathrm{~mL}$ de ácido clorídrico e 300 $\mathrm{mL}$ de ácido nítrico). 


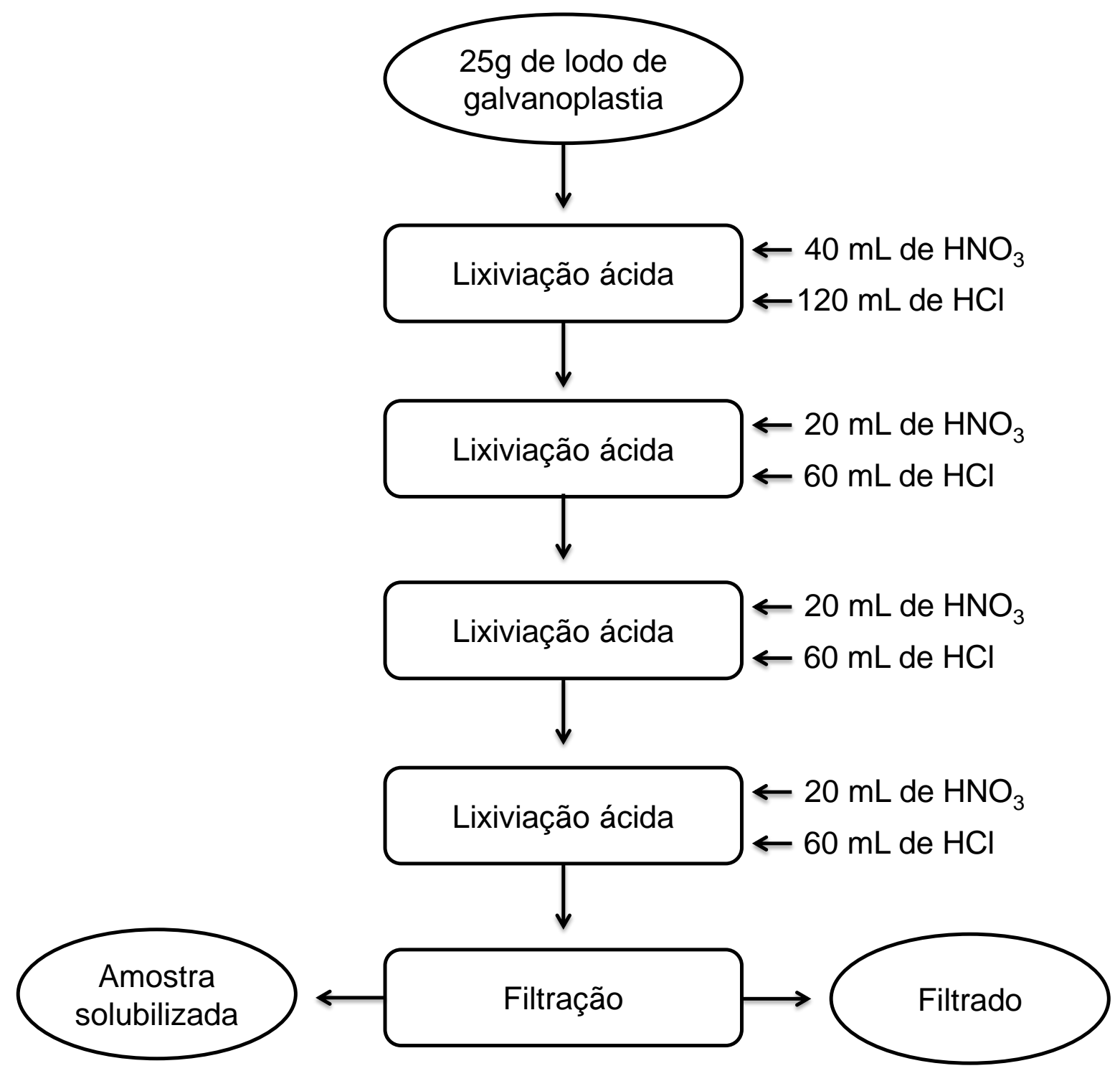

Figura 15 - Fluxograma do processo de lixiviação ácido com água régia.

As soluções ácidas foram adicionadas nas amostras de lodo de galvanoplastia, primeiramente, na proporção de $5 \mathrm{~mL}$ de ácido para um grama de amostra. No entanto, como visualmente havia uma fração da amostra que não havia dissolvido foi adicionado um volume de ácido até a proporção de $8 \mathrm{~mL}$ para um grama de amostra.

No processo de extração dos metais utilizando apenas o ácido clorídrico adotou-se a proporção de $5 \mathrm{~mL}$ de ácido para um grama de amostra. Primeiramente, adicionou-se $125 \mathrm{~mL}$ de ácido clorídrico em um balão de vidro e, em seguida, acrescido o lodo galvânico. Para realizar a lixiviação dos metais, aqueceu-se a amostra a $100 \stackrel{\circ}{\mathrm{C}}$ até secar, com o objetivo de reagir o cloro do 
ácido com os metais presentes na amostra, formando cloretos metálicos. Após seca, adicionou-se mais $125 \mathrm{ml}$ de ácido no balão para dissolver a amostra.

Devido à elevada quantidade de metais no lodo galvânico, para a remoção do cromo foi necessário realizar um processo de oxidação para converter o cromo trivalente (III) em hexavalente (VI).

O primeiro passo do processo de oxidação consistiu na transferência da amostra lixiviada para um béquer de 1 litro disposto sobre um aquecedor. Para homogeneização da amostra utilizou-se um agitador mecânico da marca IKA (modelo RW 20 digital). Em seguida ajustou-se o pH a um valor de 10 pela adição de hidróxido de sódio $(\mathrm{NaOH})$, a uma concentração de $8 \mathrm{~mol}^{\mathrm{L}} \mathrm{L}^{-1}$, para realizar a precipitação dos metais e do cálcio remanescente na forma de hidróxidos.

Realizada a precipitação dos metais, efetuou-se a oxidação do cromo com peroxido de hidrogênio, conforme pode ser observado nas Figuras 17 e 18. De acordo com os estudos realizados por Kuchar et al. (2010) e Silva et al. (2006), a eficiência de processo de oxidação do cromo varia em função de três parâmetros, sendo eles a temperatura, o tempo de reação e concentração de peróxido de hidrogênio utilizado.
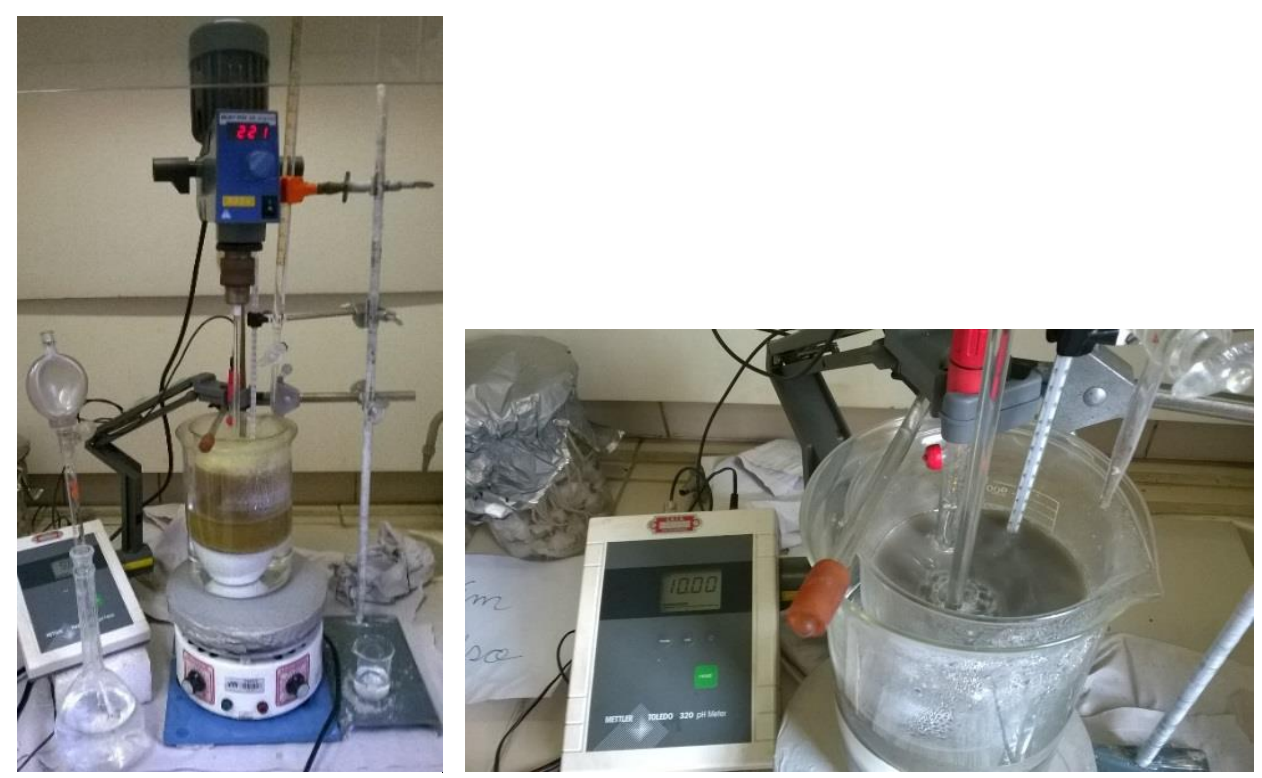

Figuras 16 e 17 - Processo de oxidação do cromo.

Segundo Kuchar et al. (2010) e Silva et al. (2006), os resultados com meIhor custo/benefício foram obtidos com aquecimento da amostra a $60{ }^{\circ} \mathrm{C}$. Para se avaliar a influência da temperatura no processo de recuperação do cromo, reali- 
zou-se uma análise a temperatura ambiente e três análises foram aquecidas a uma faixa de temperatura de $40^{\circ} \mathrm{C}$ a $80^{\circ} \mathrm{C}$, variando em $20^{\circ} \mathrm{C}$, utilizando um agitador magnético com aquecimento da marca Quimis (modelo Q261-22). Os outros dois parâmetros, tempo de reação e concentração de peróxido de hidrogênio, foram mantidos nas condições ideais apresentadas por estes autores, sendo o tempo de 60 minutos e a concentração de $\mathrm{H}_{2} \mathrm{O}_{2}$ de 3,00 mol. $\mathrm{L}^{-1}$.

As amostras foram aquecidas em banho-maria, por este método realizar 0 aquecimento uniforme da amostra e auxiliar na estabilização da temperatura no processo de oxidação.

Utilizou-se como agente oxidante o peróxido de hidrogênio, sendo a reação de oxidação apresentada na equação 2. Segundo Silva et al. (2006), o $\mathrm{H}_{2} \mathrm{O}_{2}$ apresenta vantagens em relação aos outros agentes utilizados, tais como 0 hipoclorito de sódio, que pode reagir com o material orgânico presente no lodo galvânico e gerar compostos organoclorados nocivos e o ozônio, que apresar de se um agente oxidante forte, seu custo de produção é consideravelmente mais elevado.

$$
2 \mathrm{CrO}_{2}^{-}+3 \mathrm{H}_{2} \mathrm{O}_{2} \rightarrow 2 \mathrm{CrO}_{4}^{2-}+\mathrm{OH}^{-}+\mathrm{H}_{2} \mathrm{O}
$$

A concentração de $\mathrm{H}_{2} \mathrm{O}_{2}$ utilizada no estudo foi baseada nos experimentos realizados em dois estudos, sendo eles:

Kuchar et al. (2010), onde realizou-se uma variação na razão molar da reação entre $\mathrm{H}_{2} \mathrm{O}_{2}$ e cromo trivalente (baseado na equação 2) na ordem de 1,8 a 180, apresentado melhor resultado na razão 18;

Silva et al. (2006), obteve em seu estudo a melhor eficiência utilizando uma concentração de 1,40 mol.L-1 para uma massa de cromo de 2.424,50 mg.L-1.

Para oxidar a amostra contendo cromo adotou-se uma concentração molar de $\mathrm{H}_{2} \mathrm{O}_{2}$ de 3,00 mol.L-1. Também se utilizou concentrações de 1,50 e 4,50 mol.L1, para avaliar a eficiência do processo em função da variação deste parâmetro. Mantiveram-se fixos a temperatura a 60ำ e o tempo de reação em 60 minutos.

O tempo de reação também é um fator preponderante na eficiência do processo de oxidação. Kuchar et al. (2010) obtive os melhores resultados utilizando um tempo de 60 minutos. No entanto, o estudo realizado por Silva et al. (2006) 
considera como tempo ideal o de 40 minutos, por apresentar a melhor eficiência de oxidação. Portanto, para obter o melhor tempo de reação, realizou-se a variação no tempo de reação de 30, 60 e 90 minutos.

\subsubsection{Recuperação do cromo sem o processo de lixiviação}

O segundo processo consiste na recuperação do cromo utilizando o lodo de galvanoplastia bruto. Como não há lixiviação ácida, adicionou-se o lodo diretamente em um béquer de 1 litro com água deionizada. A mistura foi aquecida utilizando o agitador magnético com aquecimento da marca Quimis (modelo Q261-22) e homogeneizada pelo agitador mecânico da marca IKA (modelo RW 20 digital).

O lodo galvânico é um material proveniente de um processo de precipitação química. Segundo Magalhães et al. (2005) nas ETEs o efluente é tratado a pH próximo a 8,50, sendo necessário adição de hidróxido de sódio $(\mathrm{NaOH})$ para ajuste do $\mathrm{pH}$ ao valor de 10,00.

Efetuado o ajuste do $\mathrm{pH}$, realizou-se a recuperação do cromo pelo mesmo processo de oxidação apresentado no Processo 1. Para se comparar os dois processos, efetuou-se as mesmas variações de tempo, concentração de peróxido de hidrogênio e temperatura executadas no Processo 1, com exceção da a amostra realizada a temperatura ambiente, por apresentar a menor eficiência de oxidação.

\subsection{Avaliação dos processos 1 e 2}

O cálcio presente no lodo de galvanoplastia pode interferir na eficiência do processo de oxidação do cromo, conforme apresentado no item 4.3.1.1, motivo pelo qual no Processo 1 realizou-se uma etapa para sua remoção. Este elemento representa mais de $20,00 \%$ do total de resíduo gerado. Portanto, sua remoção representa uma redução considerável no custo de destinação final do lodo de galvanoplastia, uma vez que o cálcio não é considerado um resíduo perigoso.

O processo para recuperação de metais só é viável caso os elementos removidos do lodo galvânico possam ser reutilizados, garantindo a eles uma destinação final ambientalmente adequada. 
O tratamento de oxidação recupera o cromo na forma de dicromato, podendo assim reutilizá-lo nos banhos de deposição de cromo. A reutilização do cromo resulta em ganhos econômicos, tais como a redução do consumo de ácido crômico e redução do custo de destinação do lodo galvânico gerado. Promove-se também ganhos ambientais, pois reduz a probabilidade deste material ser destinado para um local ambientalmente incorreto e minimiza a criação de passivos ambientais.

Para avaliar a viabilidade econômica da remoção do cromo, realizou-se uma análise custo/benefício dos dois processos de oxidação. Por meio da determinação dos volumes de insumos químicos utilizados e dos seus respectivos preços de mercado, quantificaram-se os custos dos dois processos por grama de cromo removido.

O Processo 1 utilizou ácido clorídrico, ácido nítrico, hidróxido de sódio e peróxido de hidrogênio. A determinação dos volumes de cada insumo químico e seus respectivos preços de mercado permitiu quantificar o custo deste processo de remoção. Comparou-se o valor obtido com o preço de mercado do ácido crômico utilizado na empresa, permitindo assim avaliar a sua viabilidade econômica.

Como no Processo 2 não há a lixiviação ácida, os insumos químicos utilizados foram o hidróxido de sódio e o peróxido de hidrogênio. Consequentemente, o custo total é inferior ao do Processo 1. No entanto, para determinar a viabilidade econômica compararam-se os custos obtidos com os do Processo $1 \mathrm{e}$ com o preço de mercado do ácido crômico. 


\section{RESULTADOS E DISCUSSÃO}

De acordo com os procedimentos adotados para a realização deste trabalho, é apresentado nos resultados a caracterização do lodo de galvanoplastia, as eficiências de remoção de cálcio e cromo no Processo 1 e de cromo no Processo 2 e a determinação dos custos dos dois processos.

\subsection{Preparação e caracterização do lodo de galvanoplastia}

O teor de umidade do lodo de galvanoplastia, calculado com a massa seca e úmida do material, é de 59,35\% em massa. Essa quantificação está de acordo os elevados teores de umidade do lodo galvânico apresentados por Magalhães et al. (2005), que são em média de $60,00 \%$ em massa. Um processo de desidratação eficiente seria capaz de reduzir a quantidade de lodo gerada, reduzindo os custos de armazenamento e destinação.

Realizou-se no lodo de galvanoplastia seco, primeiramente, a análise de fluorescência de raios $X$ por energia dispersiva para detectar os principais elementos presentes no resíduo. Os resultados desta análise encontram-se no Apêndice A e apresentados na Figura 19.

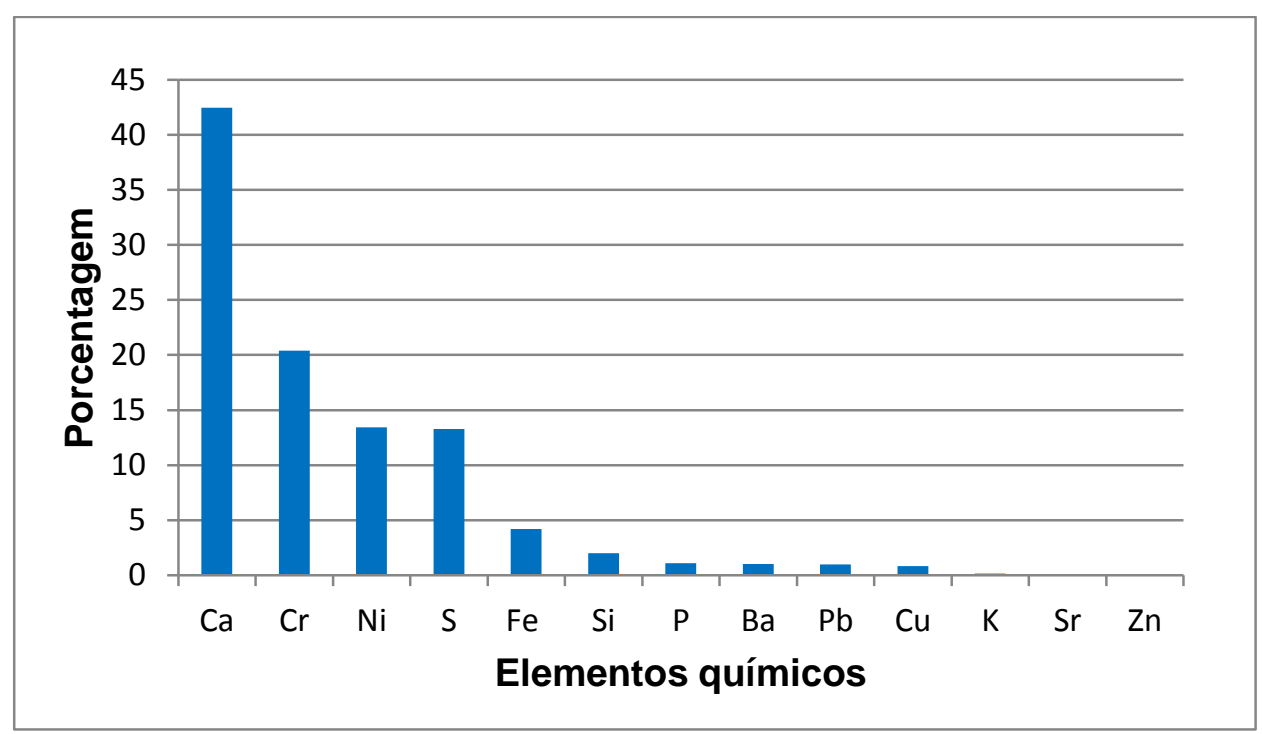

Figura 18 - Composição mássica do lodo de galvanoplastia.

Os elementos mais preponderantes no resíduo são o cálcio, resultante do hidróxido de cálcio utilizado no tratamento de efluentes e o cromo, proveniente da 
etapa de cromação. O níquel, ferro e enxofre, proveniente principalmente do ácido sulfúrico, foram encontrados em médias proporções. Os demais elementos constituem uma pequena parcela do lodo, o potássio ( $0,14 \%$ em massa), o estrôncio $(0,10 \%$ em massa) e o zinco $(0,07 \%$ em massa), não sendo relevantes para o estudo.

A partir da análise de FRX-EDX realizou-se a análise quantitativa ICP-OES para obter os teores exatos dos elementos presentes no lodo galvânico, sendo os resultados apresentados na Tabela 2. Como o resíduo sólido galvânico é muito heterogêneo, apresentaram-se na tabela apenas os elementos mais relevantes ao estudo e/ou que apresentam risco ao meio ambiente.

No entanto, análise de ICP-OES não é capaz de detectar o enxofre, considerado preponderante na análise de FRX-EDX. Portanto, para determinar o teor de enxofre e carbono na amostra efetuou-se a análise de cromatografia por absorção gasosa, sendo o resultado apresentado na Tabela 2.

Tabela 3 - Principais elementos químicos presentes no lodo de galvanoplastia, obtidos pelas análises de ICP-OES e Cromatografia gasosa.

\begin{tabular}{cc}
\hline Elemento & Concentração (\% em massa) \\
\hline $\mathrm{Ca}$ & 20,05 \\
\hline $\mathrm{C}$ & 10,28 \\
\hline $\mathrm{Cr}$ & 6,52 \\
\hline $\mathrm{S}$ & 5,55 \\
\hline $\mathrm{Ni}$ & 4,33 \\
\hline $\mathrm{Si}$ & 1,41 \\
\hline $\mathrm{Fe}$ & 1,18 \\
\hline $\mathrm{Mg}$ & 0,53 \\
\hline $\mathrm{Na}$ & 0,44 \\
\hline $\mathrm{Cu}$ & 0,32 \\
\hline $\mathrm{B}$ & 0,11 \\
\hline $\mathrm{Zn}$ & 0,04 \\
\hline Total & $\mathbf{5 0 , 7 6}$
\end{tabular}




\subsection{PROCESSO 1 - REMOÇÃO DO CÁLCIO E CROMO}

\subsubsection{Remoção do cálcio}

Para determinar a eficiência do processo de remoção do cálcio mediante a adição de ácido cítrico, realizaram-se três análises variando a razão ácido cítrico/hidróxido de cálcio, permitindo assim avaliar eficiência do processo em função da massa de ácido cítrico utilizado, como pode ser observado na Figura 12.

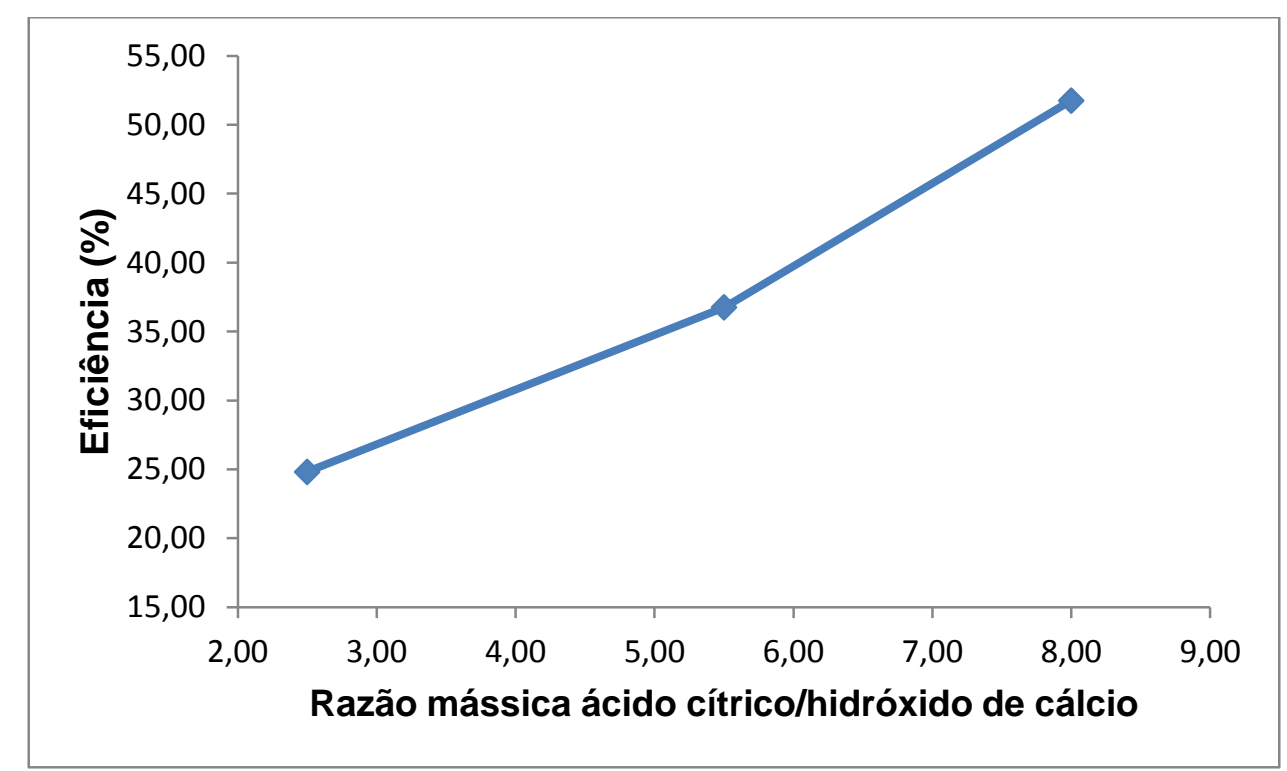

Figura 19 - Eficiência do processo de remoção do cálcio em função da razão mássica de ácido cítrico/hidróxido de cálcio.

Encaminharam-se as três soluções, após a filtração, para as análises de FRX-EDX e ICP-OES, sendo seus resultados apresentados na Figura 20 e na Tabela 3, respectivamente.

$\mathrm{Na}$ Figura 20 são apresentados os elementos que constituem as amostras, sendo o níquel, cálcio e o cromo os mais preponderantes (valores apresentados no Apêndice B). Comparando com a análise inicial (Figura 19), observou-se a redução no teor de cálcio e a elevação da porcentagem dos demais elementos, indicando a remoção deste elemento no processo de filtração. 


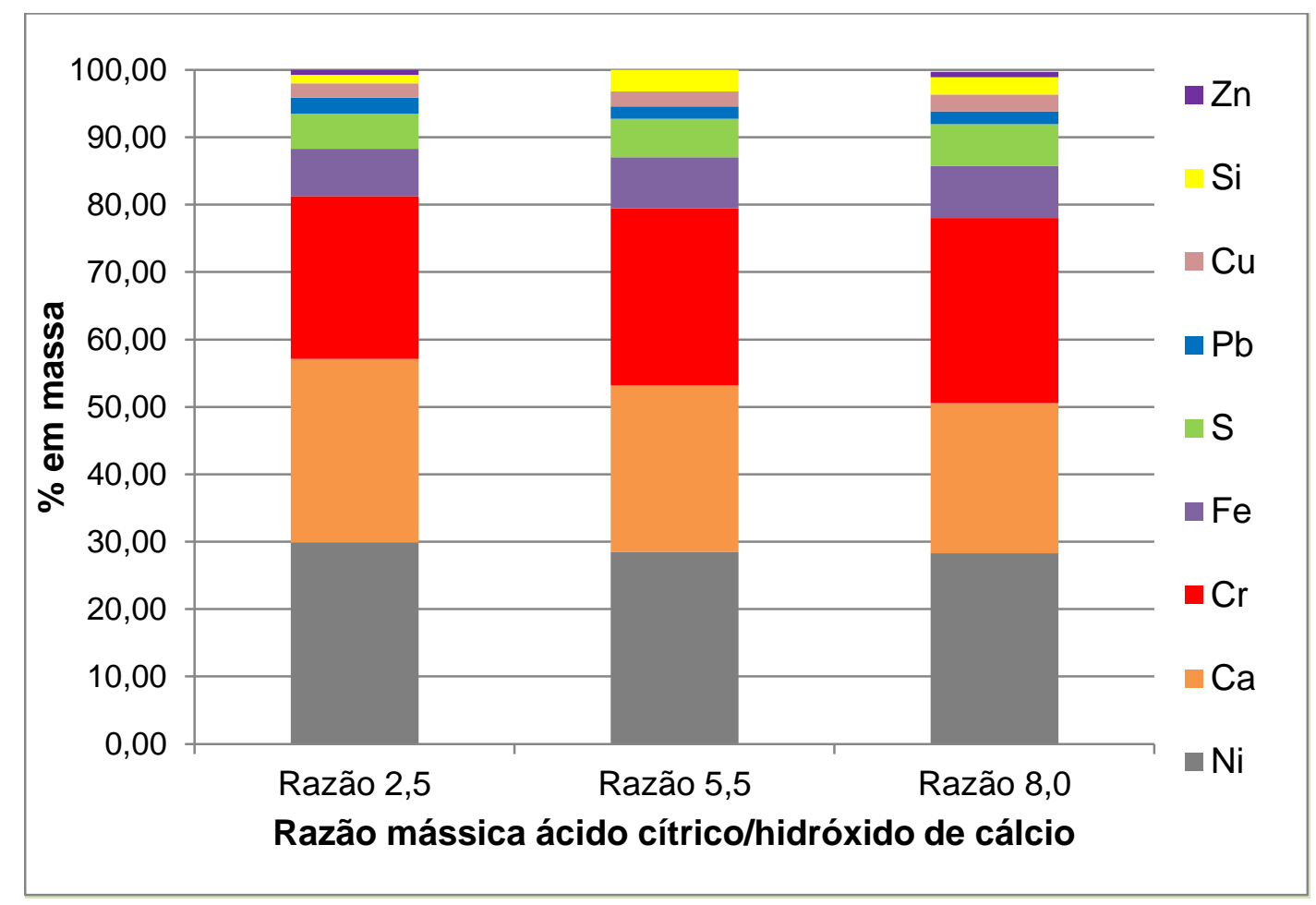

Figura 20 - Composição mássica das três amostras filtradas.

As três amostras filtradas foram encaminhadas à análise de ICP-OES para se determinar a concentração do cálcio na solução. Para avaliar a eficiência do processo de remoção do cálcio, quantificou-se também a concentração inicial do elemento em estudo, sendo os resultados da caracterização das amostras e das eficiências do processo de remoção do cálcio apresentados na Tabela 3.

Tabela 4 - Caracterização das três amostras filtradas e eficiência do processo de remoção do cálcio.

\begin{tabular}{cccc}
\hline Análises & $\begin{array}{c}\text { Concentração inicial } \\
\left(\mathbf{g} \cdot \mathbf{L}^{-1}\right)\end{array}$ & $\begin{array}{c}\text { Concentração final } \\
\left(\mathbf{g} \cdot \mathbf{L}^{-1}\right)\end{array}$ & $\begin{array}{c}\text { Eficiência } \\
\text { (\%) }\end{array}$ \\
\hline $\begin{array}{c}\text { Razão } \\
2,5\end{array}$ & 6,39 & 4,80 & 24,83 \\
\hline $\begin{array}{c}\text { Razão } \\
5,5\end{array}$ & 6,40 & 4,05 & 36,75 \\
\hline $\begin{array}{c}\text { Razão } \\
8,0\end{array}$ & 6,38 & 3,08 & 51,76 \\
\hline
\end{tabular}

De acordo com os resultados apresentados na Tabela 3, percebeu-se que a eficiência do processo de remoção de cálcio varia em função da razão mássica 
ácido cítrico/hidróxido de cálcio utilizada, obtendo-se a melhor eficiência com a maior razão de 8, responsável pela remoção de mais de 50,00\% do cálcio.

Determinada a eficiência do processo de remoção do cálcio, com base nas concentrações apresentadas na Tabela 3, quantificou-se a massa de cálcio removida em cada razão, sendo os resultados apresentados na Tabela 4. Também se determinou o custo do ácido cítrico utilizado em cada análise, utilizando o valor médio das cotações realizadas em 20 de maio de 2015 (os custos em dólar comercial são apresentados no Apêndice C). Com estas duas informações, se calculou o custo por grama do ácido cítrico utilizado em cada razão, conforme apresentado na Tabela 4.

Tabela 5 - Custo da extração do cálcio baseado na massa de ácido cítrico.

\begin{tabular}{ccccc}
\hline Análises & $\begin{array}{c}\text { Eficiência } \\
(\%)\end{array}$ & $\begin{array}{c}\text { Massa Ca extra- } \\
\text { ída (g) }\end{array}$ & $\begin{array}{c}\text { Custo ácido cí- } \\
\text { trico (R\$) }\end{array}$ & $\begin{array}{c}\text { Custo por } \\
\text { grama (R\$) }\end{array}$ \\
\hline $\begin{array}{c}\text { Razão } \\
2,5\end{array}$ & 24,83 & 1,19 & 0,84 & 0,71 \\
\hline $\begin{array}{c}\text { Razão } \\
5,5\end{array}$ & 36,75 & 1,76 & 1,74 & 0,99 \\
\hline $\begin{array}{c}\text { Razão } \\
8,0\end{array}$ & 51,76 & 2,49 & 2,52 & 1,01 \\
\hline
\end{tabular}

Percebe-se que a razão entre a eficiência do processo de extração do cálcio e o seu custo não é linear. Enquanto a eficiência do processo dobra entre a razão mássica de 2,50 e 8,00 (24,83\% em massa e 51,76\% em massa, respectivamente), o custo de remoção triplica de $R \$ 0,84$ para $R \$ 2,52$. Visto que a eficiência da razão 2,50 é praticamente a metade da análise de 8 , caso mantida a linearidade o custo seria de $R \$ 1,75$, e não $R \$ 2,52$.

O custo médio, por tonelada, da destinação ambientalmente correta do lodo de galvanoplastia de uma empresa localizada na zona leste do município de São Paulo é de $R \$ 350,00$ para disposição em aterro classe I ou de $R \$ 650,00$ para coprocessamento. Diante destes valores de destinação e do custo de extração do cálcio, apresentado na Tabela 4, nota-se que a remoção deste elemento para redução do volume de lodo galvânico a ser destinado como resíduo classe I não é economicamente viável, visto que se gastaria em média $R \$$ 1.000,00 para remover um quilograma de cálcio. 
Para avaliar a composição do precipitado retido na filtração, após a secagem do material, encaminhou-se o mesmo à análise de FRX-EDX. Os resultados desta análise encontram-se no Apêndice $D$ e apresentados na Figura 21. De acordo com os resultados obtidos, o precipitado é constituído principalmente de cálcio e enxofre. Os demais elementos, dentre eles o cromo e o níquel, constam apenas em pequenas proporções, demonstrando assim que esta etapa não afeta o processo seguinte de recuperação destes metais.

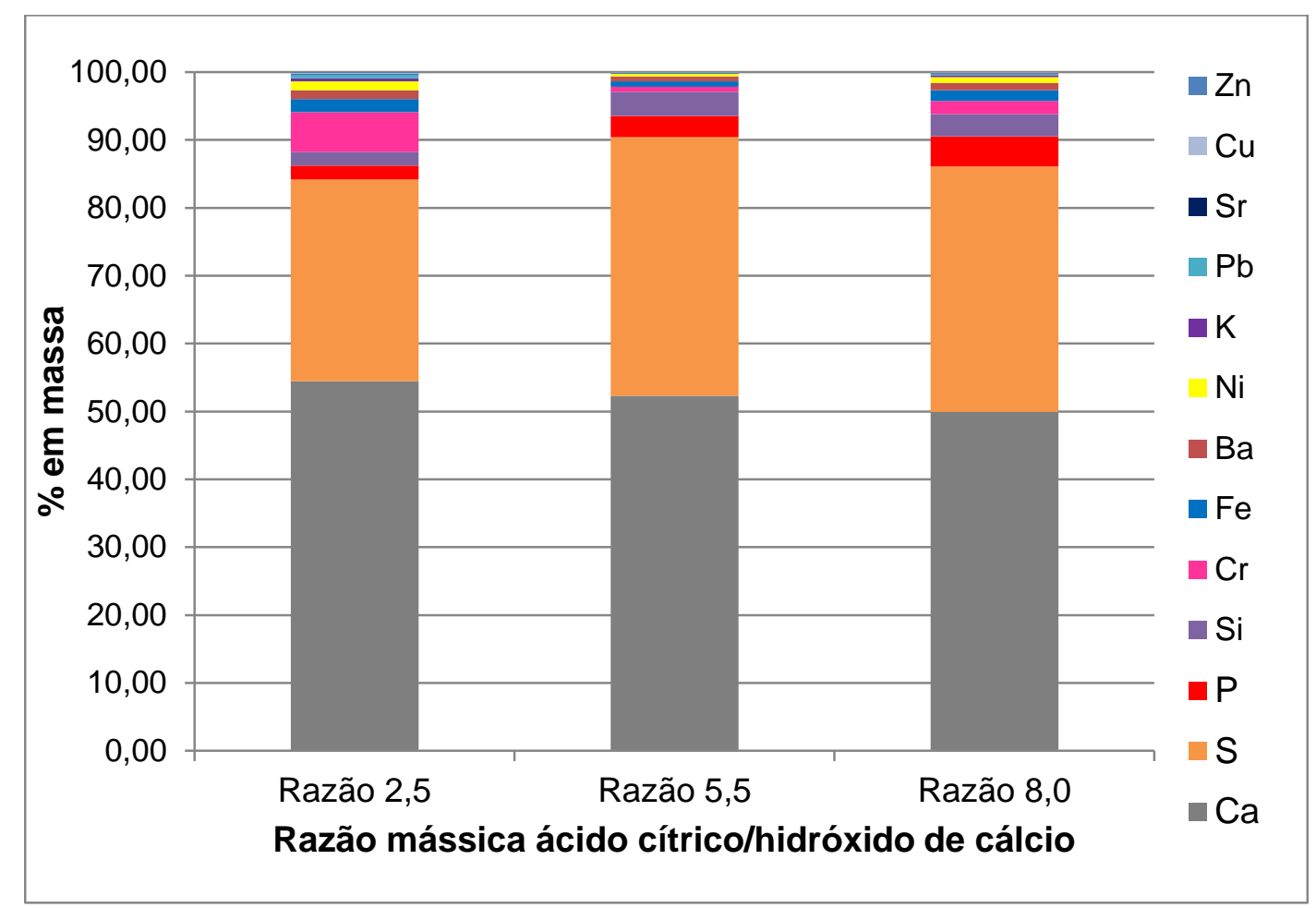

Figura 21 - Composição mássica do precipitado removido por filtração.

Como os resultados de FRX-EDX indicaram a presença de cromo no material oriundo do processo de extração do cálcio, realizou-se a lixiviação deste precipitado de acordo com a ABNT NBR 10.005/04 (procedimento para obtenção de extrato lixiviado de resíduos sólidos) para determinação da sua classificação segunda a ABNT NBR 10.004/04.

Realizou-se a caracterização da amostra lixiviada por meio da análise de ICP-OES, que indicou uma concentração de cromo de 0,48 g.L-1. Como no Anexo F da ABNT NBR 10.004/04 a concentração limite deste elemento para extrato obtido no ensaio de lixiviação é de $5,00 \mathrm{~g} \cdot \mathrm{L}^{-1}$, segundo esta norma, o precipitado obtido no processo de extração do cálcio é considerado não perigoso. 


\subsubsection{Recuperação do cromo por processo de lixiviação}

\subsubsection{Processo de lixiviação da amostra}

Para realizar a recuperação do cromo no processo um, primeiramente se realizou a lixiviação ácida da amostra. Como mencionado anteriormente, utilizouse três soluções: água régia, água régia invertida e ácido clorídrico puro.

Encaminharam-se as três amostras lixiviadas para a análise de ICP-OES, sendo os resultados apresentados na Tabela 5. A amostra lixiviada com água régia obteve as maiores concentrações de cromo e níquel, seguido pela água régia invertida e o ácido clorídrico.

Tabela 6 - Análise das amostras lixiviadas pela técnica de ICP-OES.

\begin{tabular}{ccc}
\hline Agente Extrator & Concentração $\mathbf{C r}\left(\mathbf{g} \cdot \mathbf{L}^{-1}\right)$ & Concentração $\mathbf{~ i ~}\left(\mathbf{g} \cdot \mathbf{L}^{-1}\right)$ \\
\hline Água régia & 2,62 & 1,49 \\
\hline Água régia invertida & 2,38 & 1,35 \\
\hline Ácido clorídrico & 2,16 & 1,33 \\
\hline
\end{tabular}

Diante dos resultados obtidos percebeu-se que a solução de água régia apresentou a maior eficiência na extração de metais do resíduo de galvanoplastia. No entanto, o ácido nítrico possui um valor médio de mercado de $\mathrm{R} \$ 30,70$ por litro (cotação realizada em maio de 2015), enquanto a do ácido clorídrico é de $R \$$ 18,40. O custo do ácido nítrico dificulta a viabilidade econômica da sua utilização em processo de recuperação de metais em larga escala, conforme apresentado na Tabela 6. Os custos dos três agentes extratores em dólar comercial são apresentados no Apêndice C. A utilização do ácido clorídrico como agente extrator se mostrou uma opção viável, visto que comparativamente a água régia, obteve-se um teor de extração de níquel de $89,76 \%$ e cromo de $82,52 \%$, em massa.

Como o presente trabalho utilizou o lodo, oriundo da estação de tratamento de efluentes, sugere-se para estudos futuros de recuperação de metais em galvanoplastias a utilização do efluente gerado no processo antes que o mesmo chegue a ETE, pois assim evitaria a necessidade da lixiviação ácida da amostra e, consequentemente, reduziria os custos da recuperação dos metais. 
Tabela 7 - Custos da lixiviação ácida por grama de lodo de galvanoplastia, considerando os três agentes extratores.

\begin{tabular}{cc}
\hline Agente Extrator & Custo da lixiviação por grama de lodo $(\mathbf{R} \mathbf{\$})$ \\
\hline Água régia & 0,27 \\
\hline Água régia invertida & 0,35 \\
\hline Ácido clorídrico & 0,22 \\
\hline
\end{tabular}

As frações precipitadas das três amostras foram encaminhadas para as análises de FRX-EDX, sendo os resultados apresentados na Figura 22 e no Apêndice E. Percebe-se que as amostras dissolvidas com ácido nítrico em conjunto com o ácido clorídrico foram mais eficientes na lixiviação dos metais, mais especificamente o cromo, do que a utilização do ácido clorídrico puro, de acordo com os resultados obtidos na ICP-OES.

Os resultados apresentados na Figura 22 contém alumínio na composição mássica do precipitado. Este elemento não foi identificado na análise preliminar de FRX-EDX, realizada no lodo de galvanoplastia seco a $110^{\circ} \mathrm{C}$ por 24 horas (Figura 19). A presença do alumínio se deve, provavelmente, ao recipiente de alumina (cadinho) utilizado na calcinação das amostras (800ํํ por 3 horas) para queima do papel filtro.

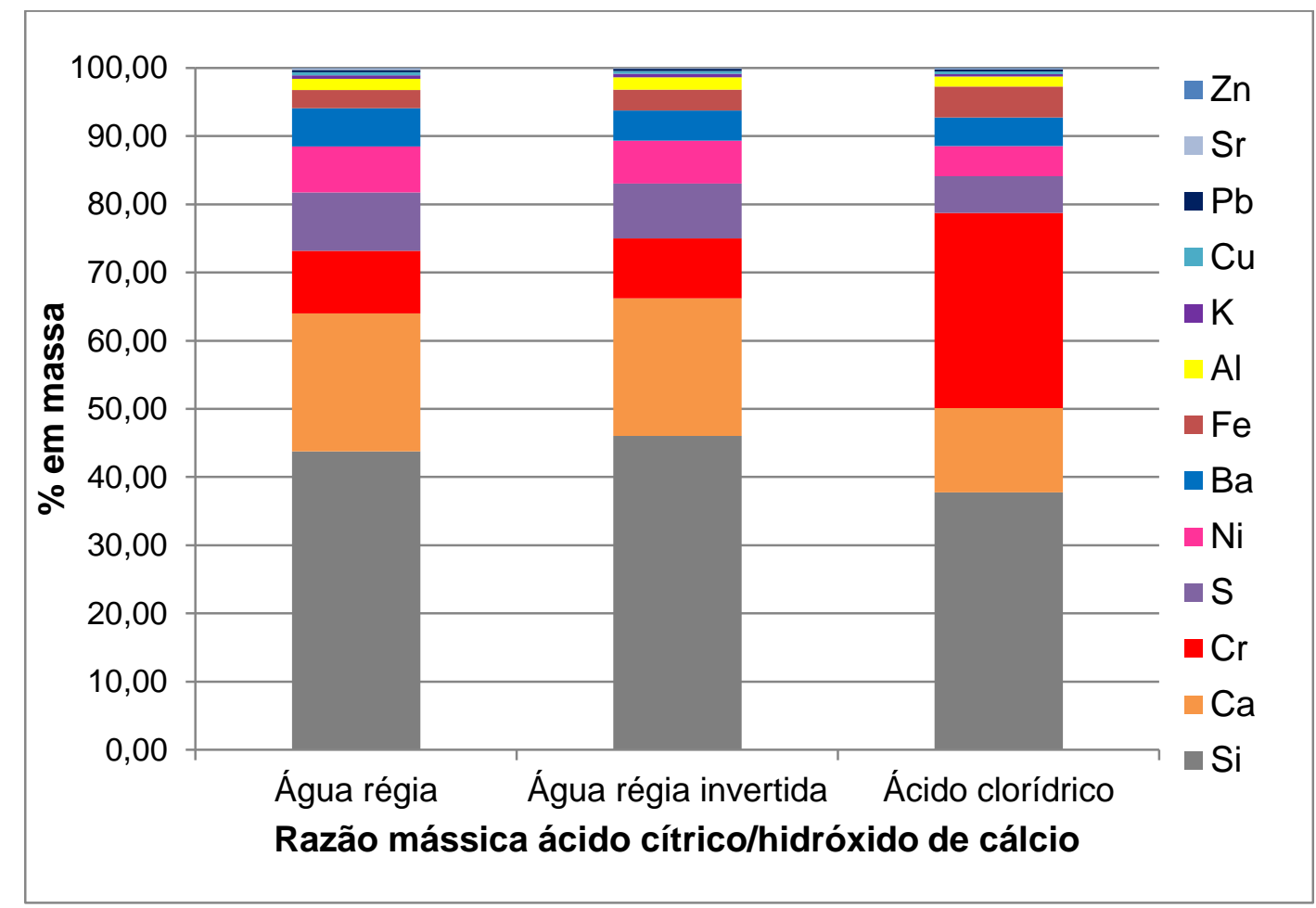

Figura 22 - Composição mássica do precipitado das três lixiviações ácidas. 


\subsubsection{Processo de oxidação do cromo}

Kuchar et al. (2010) e Silva et al. (2006) obtiveram o melhor desempenho de oxidação com o aquecimento da amostra a $60^{\circ} \mathrm{C}$ por uma hora. Portanto, a primeira analise realizada considerou estes parâmetros de processo, para verificar a correlação do processo em estudo com os dados apresentados na literatura, obtendo-se uma eficiência de 31,68\% em massa.

Realizou-se uma análise a temperatura ambiente e três análises aquecidas a uma faixa de temperatura de $40^{\circ} \mathrm{C}, 60^{\circ} \mathrm{C}$ e $80^{\circ} \mathrm{C}$, mantendo os outros dois parâmetros fixos em 60 minutos e 3,00 mol..-1-1. Também se efetuou variações nas concentrações de peróxido de hidrogênio, 1,50, 3,00 e 4,50 mol.L-1 e no tempo de reação (30, 60 e 90 minutos), considerando a temperatura de $60^{\circ} \mathrm{C}$. Apresentouse eficiências obtidas nas variações do processo na Tabela 7.

Tabela 8 - Eficiência do processo de remoção do cromo variando a temperatura, tempo e concentração $\mathrm{H}_{2} \mathrm{O}_{2}$.

\begin{tabular}{ccccc}
\hline Amostra & $\begin{array}{c}\text { Temperatura } \\
\left({ }^{\circ} \mathrm{C}\right)\end{array}$ & $\begin{array}{c}\text { Tempo } \\
(\mathrm{min})\end{array}$ & $\begin{array}{c}\text { Concentração } \\
\mathrm{H}_{2} \mathrm{O}_{2}\left(\mathrm{~mol}^{-1} \mathrm{~L}^{-1}\right)\end{array}$ & $\begin{array}{c}\text { Eficiência } \\
\text { remoção (\%) }\end{array}$ \\
\hline 1 & 60 & 60 & 3,00 & 31,57 \\
\hline 2 & 28 & 60 & 3,00 & 21,24 \\
\hline 3 & 40 & 60 & 3,00 & 24,17 \\
\hline 4 & 80 & 60 & 3,00 & 36,30 \\
\hline 5 & 60 & 30 & 3,00 & 41,09 \\
\hline 6 & 60 & 90 & 3,00 & 29,29 \\
\hline 7 & 60 & 60 & 1,50 & 29,05 \\
\hline 8 & 60 & 60 & 4,50 & 32,53 \\
\hline
\end{tabular}

A remoção máxima obtida foi de $41,09 \%$ em massa, menor que os resultados apresentados por Kuchar et al. (2010), Silva et al. (2006), e James et al. (2000), que são de 59,00\% em massa, 92,50\% em massa e $83,00 \%$ em massa, respectivamente. No entanto, percebeu-se que esses autores não obtiveram $100,00 \%$ de eficiência. 
A presença de óxidos de cálcio, segundo James et al. (2000), pode diminuir a eficiência do processo devido à formação de cromatos de cálcio anidro insolúveis. Os resultados apresentados na Tabela 7 estão de acordo com as afirmações apresentadas por estes autores, visto as dificuldades encontradas para remoção do cromo com este agente oxidante e a presença de cálcio no lodo galvânico.

De acordo com os resultados apresentados na Tabela 7 , em relação à variação da temperatura, obteve-se a melhor eficiência a $80^{\circ} \mathrm{C}, 36,30 \% \mathrm{em}$ massa. Conforme pode ser observado na Figura 23, a eficiência do processo aumenta com a elevação da temperatura de reação, semelhantemente aos resultados apresentados por Kuchar et al. (2010), que obteve a maior eficiência de recuperação a $90^{\circ} \mathrm{C}$, embora conclua que o melhor custo/benefício se adquiriu à temperatura de $60^{\circ} \mathrm{C}$. Como os resultados obtidos demonstram que a $80^{\circ} \mathrm{C}$ a eficiência é quase $5,00 \%$ em massa superior à de $60^{\circ} \mathrm{C}$, recomenda-se a sua utilização para a matéria prima em estudo.

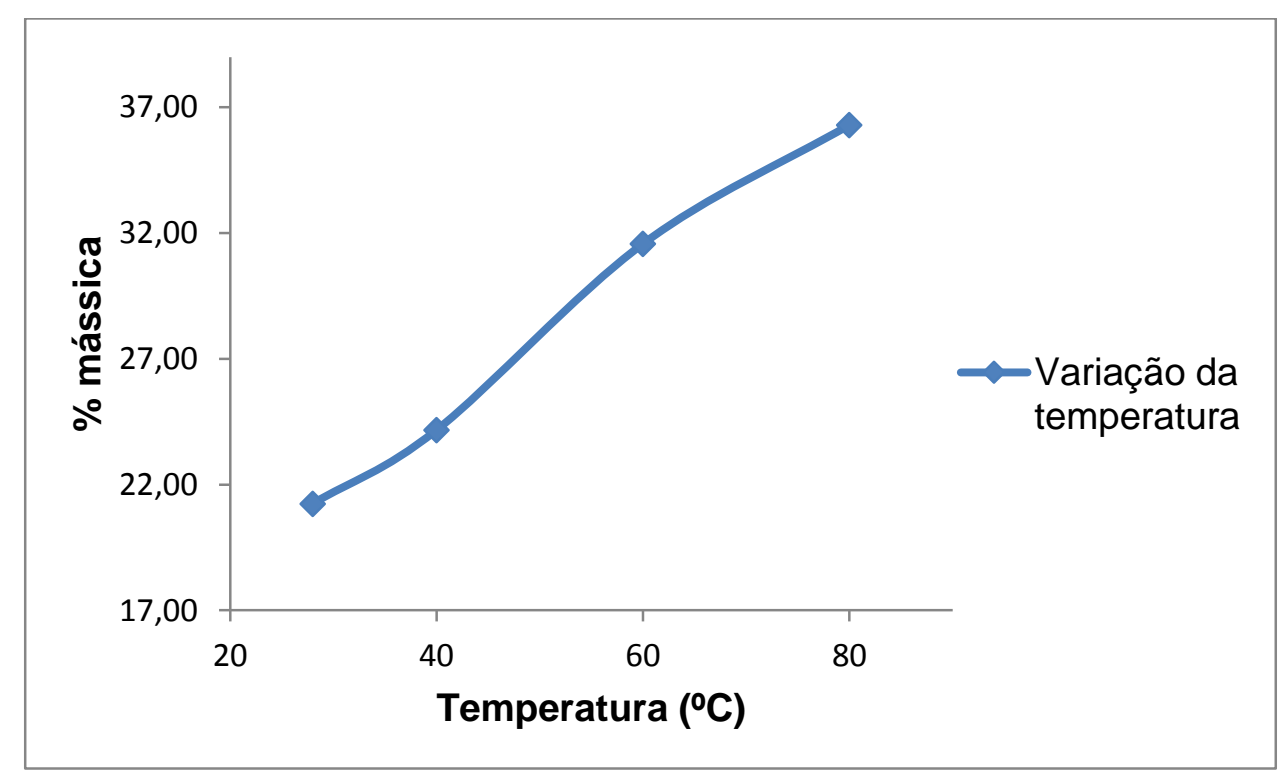

Figura 23 - Eficiência do processo de remoção de cromo em função da variação da temperatura.

A análise que obteve a maior eficiência (41,09\% em massa) utilizou o menor tempo de reação, 30 minutos. Alterando apenas o tempo e mantendo os outros dois parâmetros fixos (concentração de $\mathrm{H}_{2} \mathrm{O}_{2}$ e temperatura), os estudos realizados por Kuchar et al. (2010) e Silva et al. (2006) apresentam que o aumento do tempo de reação resultou na elevação da eficiência do processo. No 
entanto, Silva et al. (2006) obteve a mesma eficiência utilizando o tempo de 40 minutos e o de 60 minutos, reduzindo a concentração de peróxido de hidrogênio. Conforme demostrado na Figura 24, a eficiência do processo em estudo diminui com o aumento do tempo de reação. Embora ocorra a redução da eficiência entre o tempo de 60 minutos para o de 90 minutos, percebe-se que a diferença entre elas é inferior a 1,00\% em massa, demonstrando que a partir de uma hora a reação tende a se estabilizar, semelhantemente aos resultados apresentados pelos autores mencionados acima.

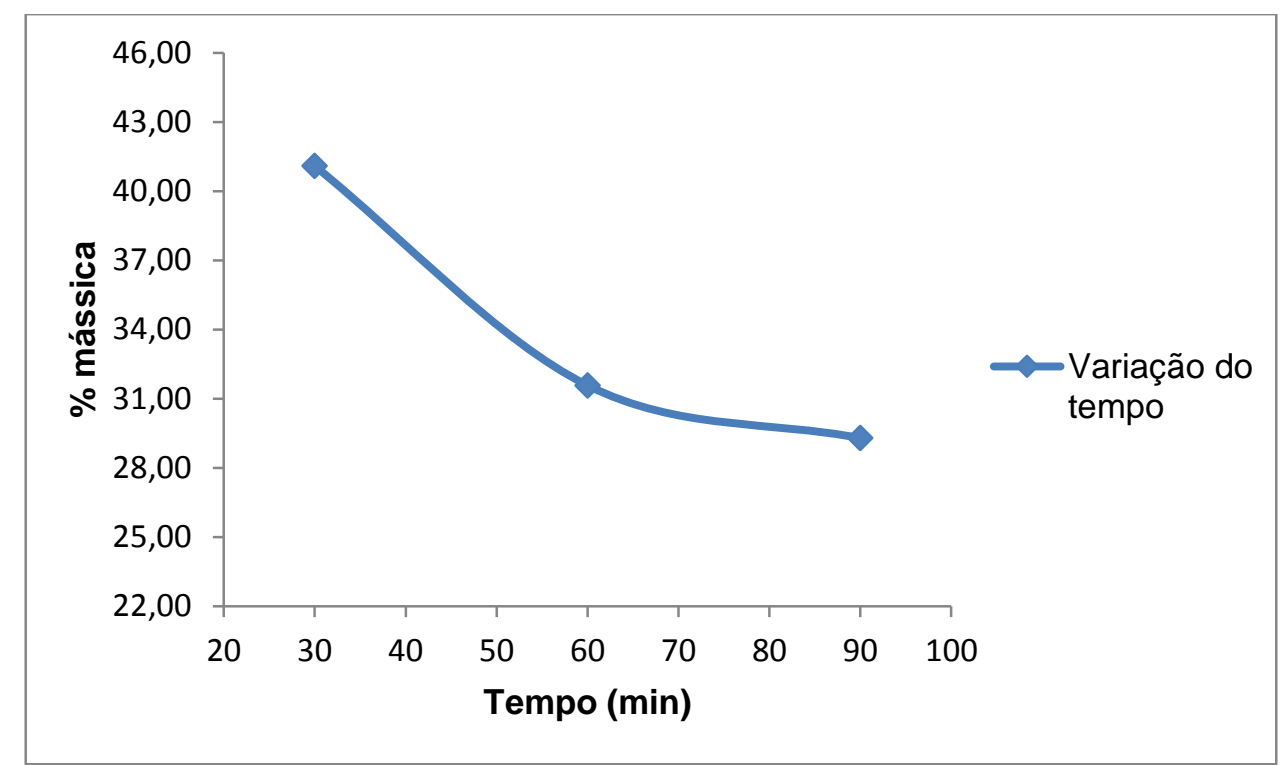

Figura 24 - Eficiência do processo de remoção de cromo em função da variação do tempo de reação.

De acordo com a Tabela 7, percebe-se que a variação na concentração de peróxido de hidrogênio não interfere de forma significativa na eficiência do processo de oxidação do cromo, conforme pode ser observado na Figura 25. A concentração molar utilizada foi calculada com base na massa total de cromo na amostra e, mediante os resultados obtidos, nota-se que a reação ocorreu em menos de $40 \%$ em massa do cromo. Por este motivo a redução da concentração molar pela metade (de 3,00 mol por litro para 1,50 mol.L-1) resultou na variação da eficiência em cerca de $2,50 \%$ em massa. A utilização de peroxido de hidrogênio em excesso também não apresentou influência significativa nos resultados, semelhantemente aos resultados apresentados por Kuchar et al. (2010), Silva et 
al. (2006), e James et al. (2000). Mediante os resultados obtidos, percebe-se que a concentração que apresenta o melhor custo/benefício é a de 1,50 mol.L-1.

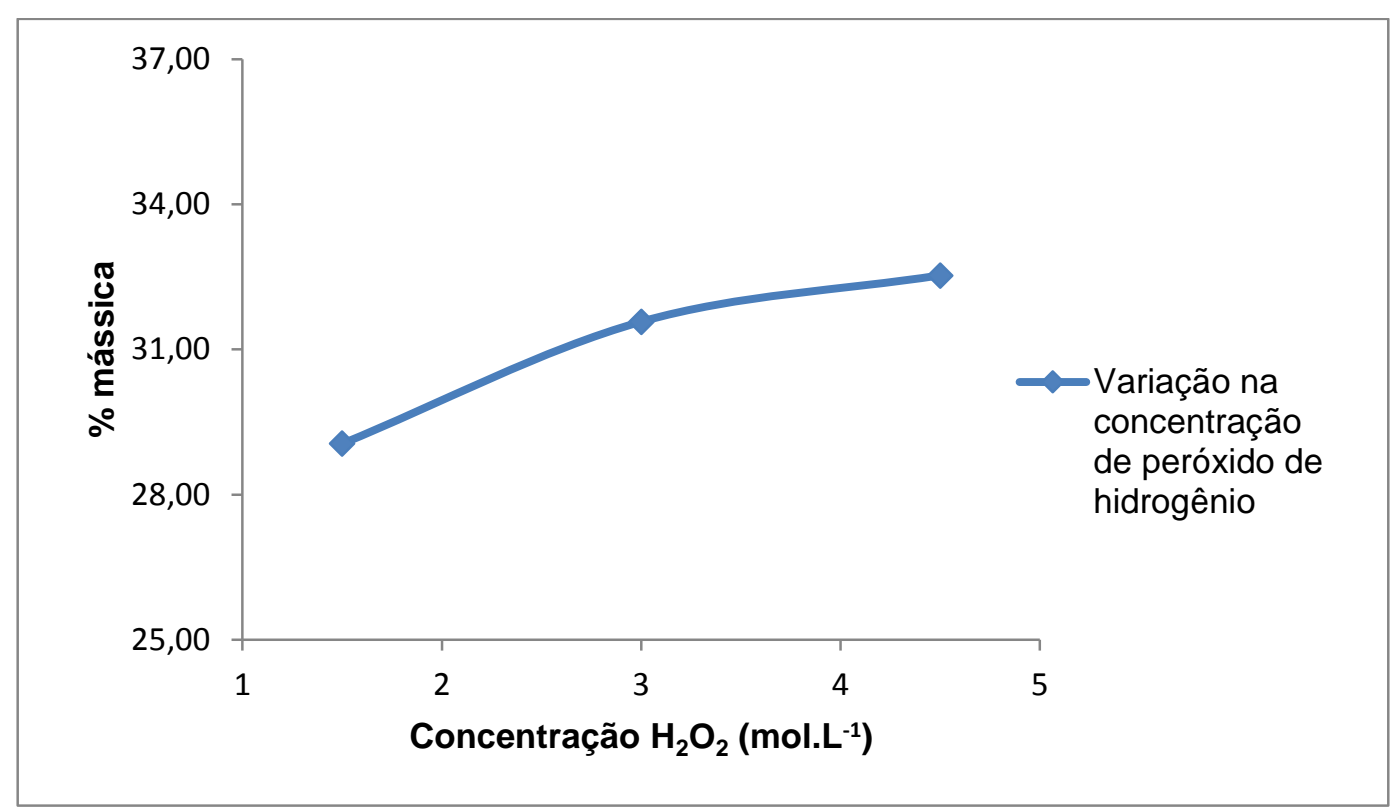

Figura 25 - Eficiência do processo de remoção de cromo em função da variação da concentração de $\mathrm{H}_{2} \mathrm{O}_{2}$.

As frações precipitadas das oito amostras foram encaminhadas para as análises de FRX-EDX. Os resultados desta análise encontram-se no Apêndice F e apresentados na Figura 26. Percebe-se que as composições mássicas das amostras variam entre $\mathrm{si}$, em função da heterogeneidade do lodo de galvanoplastia. Os resultados demonstram que a Amostra 5 , que obteve a maior eficiência de remoção, é a que contém menos cromo no precipitado. A Amostra 2, que apresentou a menor eficiência, possui o maior teor de cromo no precipitado. Ressalta-se que o cloro presente nas amostras é oriundo do ácido clorídrico utilizado na lixiviação ácida. 


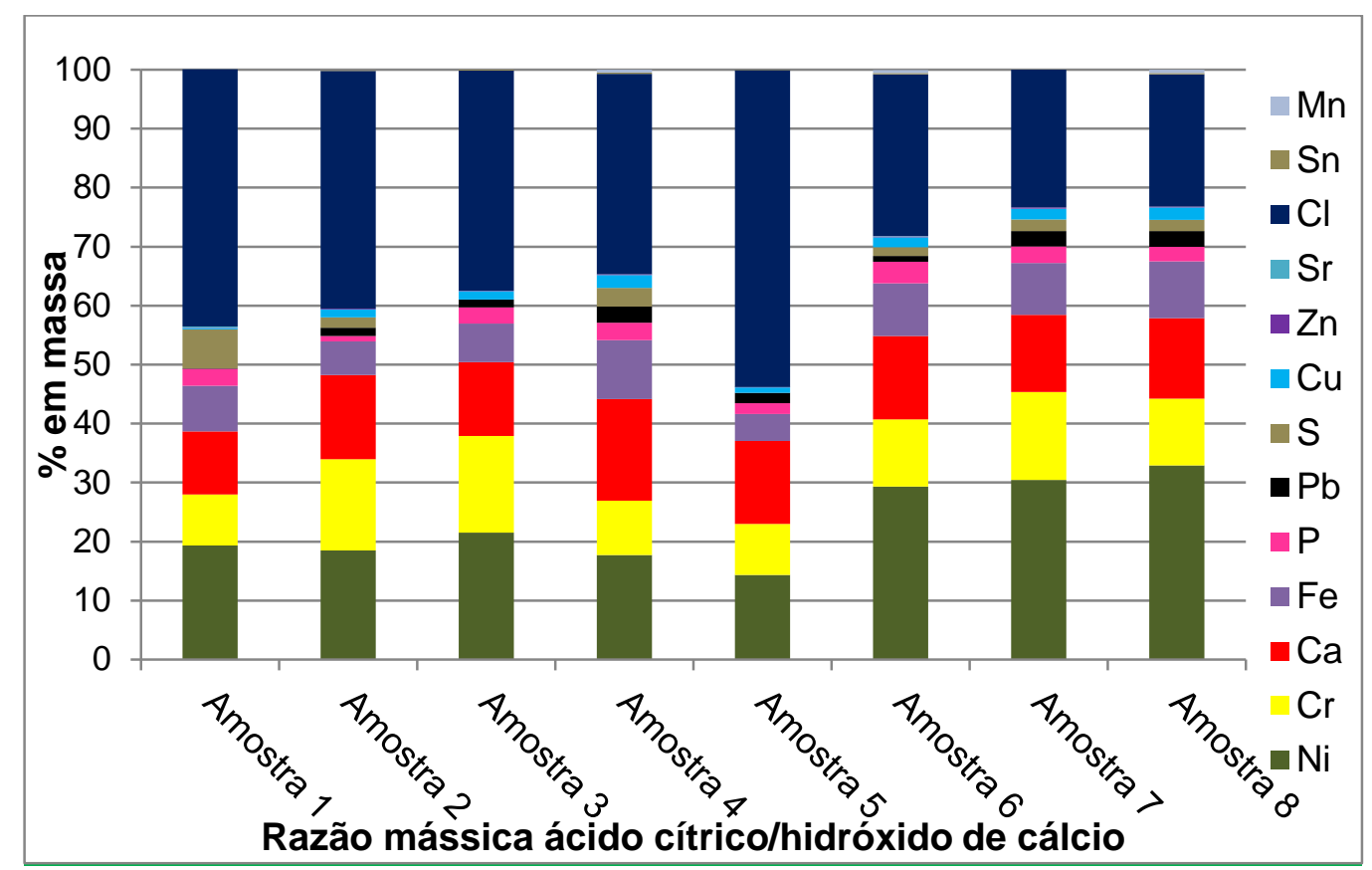

Figura 26 - Composição mássica do precipitado das oito amostras do Processo 1.

As amostras foram encaminhadas para a análise de ICP-OES, para se determinar a concentração de cromo nas frações precipitadas. Com os resultados obtidos na análise química e os valores das massas das amostras determinou-se a massa de cromo no precipitado, sendo o resultado apresentado na Tabela 8. Nesta tabela também foi apresentada a massa inicial de cromo na amostra e a de cromo nas amostras filtradas. A somatória da massa de cromo das amostras filtradas e precipitadas totalizam 0,51 gramas de cromo, que corresponde a aproximadamente $63 \%$ do total inicial.

Tabela 9 - Balanço de massa de cromo na etapa de oxidação do Processo 1 Massa de cromo na Massa de cromo no Massa de cromo no Perda $\begin{array}{lccc}\text { amostra inicial }(\mathrm{g}) & \text { filtrado }(\mathrm{g}) & \text { precipitado }(\mathrm{g}) & (\mathrm{g})\end{array}$

\begin{tabular}{llll}
\hline 0,81 & 0,34 & 0,17 & 0,30 \\
\hline
\end{tabular}

A lixiviação ácida, necessária à realização das análises de ICP-OES em amostras sólidas, não efetuou a sua solubilização total das amostras precipitadas. Então se supõem que parte da diferença quantificada entre a massa inicial de cromo e a massa determinada após a oxidação esteja presente no precipitado, mas que não foi possível determinar nas análises de ICP-OES. 
O recipiente de alumina (cadinho) mudou de coloração após a realização da calcinação das amostras, conforme pode ser observado nas Figuras 27 e 28, indicado a reação da alumina com os elementos presentes no lodo de galvanoplastia. Estudos apresentados em literatura apontam a utilização de aluminossilicatos para adsorção de metais pesados, como o realizado por Soares (2010), que avaliou a adsorção de cromo em matrizes de alumina. Supõem-se que uma fração do cromo reagiu com a alumina do cadinho durante a calcinação, sendo uma possível perda do processo.
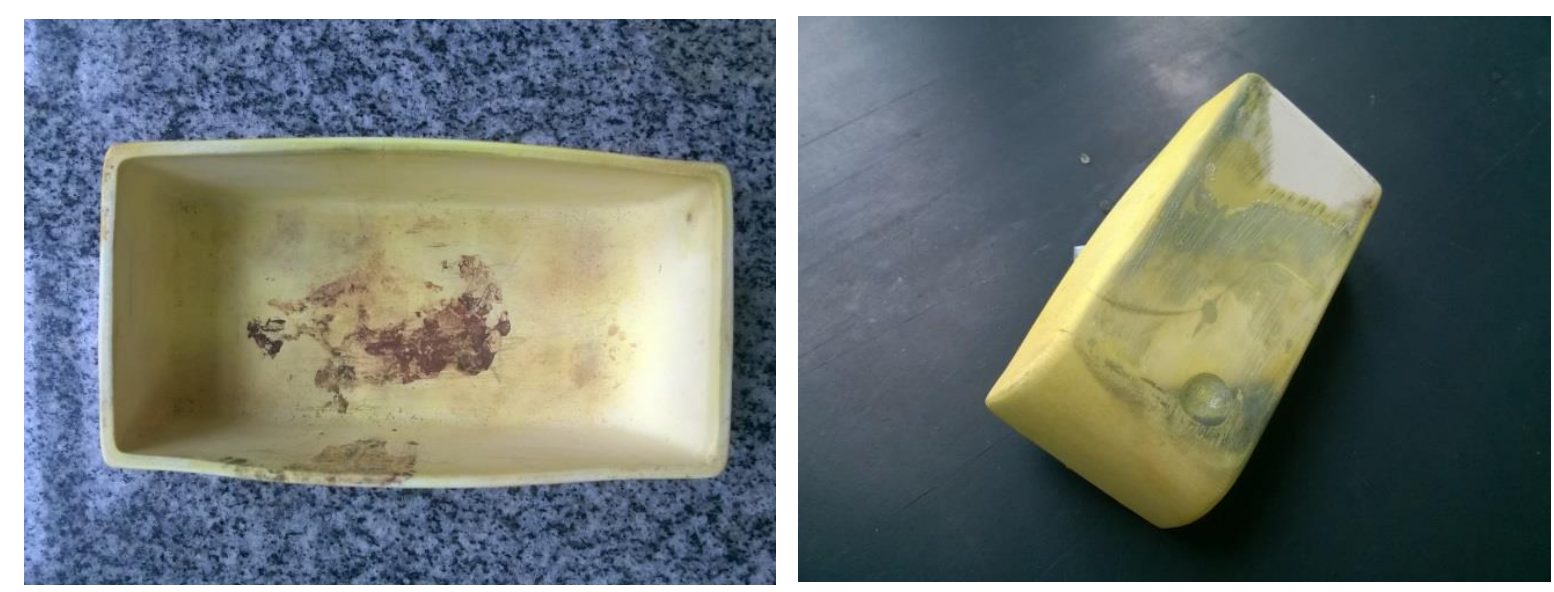

Figuras 27 e 28 - Cadinho de alumina após a calcinação das amostras precipitadas do Processo 1.

\subsubsection{Recuperação do cromo sem o processo de lixiviação}

O Processo 2 consiste na remoção do cromo utilizando o lodo galvânico bruto pelo mesmo processo de oxidação apresentado no Processo 1. As eficiências obtidas nas temperaturas de $40^{\circ} \mathrm{C}, 60^{\circ} \mathrm{C}$ e $80^{\circ} \mathrm{C}$, nas concentrações de peróxido de hidrogênio de 1,50, 3,00 e 4,50 mol.L-1 e nos tempos de reação de 30, 60 e 90 minutos são apresentadas na Tabela 9.

Tabela 10 - Eficiência do processo de remoção do cromo variando a temperatura, tempo e concentração $\mathrm{H}_{2} \mathrm{O}_{2}$.

\begin{tabular}{ccccc}
\hline Amostra & $\begin{array}{c}\text { Temperatura } \\
\left({ }^{\circ} \mathrm{C}\right)\end{array}$ & $\begin{array}{c}\text { Tempo } \\
(\mathrm{min})\end{array}$ & $\begin{array}{c}\text { Concentração } \\
\mathrm{H}_{2} \mathrm{O}_{2}\left(\mathrm{~mol} \cdot \mathrm{L}^{-1}\right)\end{array}$ & $\begin{array}{c}\text { Eficiência re- } \\
\text { moção (\%) }\end{array}$ \\
\hline 1 & 60 & 60 & 3,00 & 30,67 \\
\hline 2 & 40 & 60 & 3,00 & 15,98 \\
\hline
\end{tabular}




\begin{tabular}{ccccc}
\hline Amostra & $\begin{array}{c}\text { Temperatura } \\
\left({ }^{\circ} \mathrm{C}\right)\end{array}$ & $\begin{array}{c}\text { Tempo } \\
(\mathrm{min})\end{array}$ & $\begin{array}{c}\text { Concentração } \\
\mathrm{H}_{2} \mathrm{O}_{2}\left(\text { mol.L-1 }^{-1}\right)\end{array}$ & $\begin{array}{c}\text { Eficiência re- } \\
\text { moção (\%) }\end{array}$ \\
\hline 3 & 80 & 60 & 3,00 & 37,96 \\
\hline 4 & 60 & 30 & 3,00 & 27,17 \\
\hline 5 & 60 & 90 & 3,00 & 30,27 \\
\hline 6 & 60 & 60 & 1,50 & 15,98 \\
\hline 7 & 60 & 60 & 4,50 & 28,97 \\
\hline
\end{tabular}

A maior eficiência do processo de oxidação foi obtida a $80^{\circ} \mathrm{C}(37,96 \%$ em massa), resultado este similar ao do Processo 1 para as mesmas condições de processo. Conforme pode ser observado na Figura 29, a eficiência do processo aumenta com a elevação da temperatura de reação, semelhantemente aos resultados apresentados no Processo 1 e nos estudos realizados por Kuchar et al. (2010) e Silva et al. (2006). Nota-se que o resultado mais discrepante entre os dois processos, para este parâmetro, ocorre à temperatura de $40^{\circ} \mathrm{C}$. Mediante os resultados apresentados, percebe-se a importância do aquecimento da amostra no processo de oxidação, principalmente quando se realiza a recuperação do cromo sem o processo de lixiviação ácida.

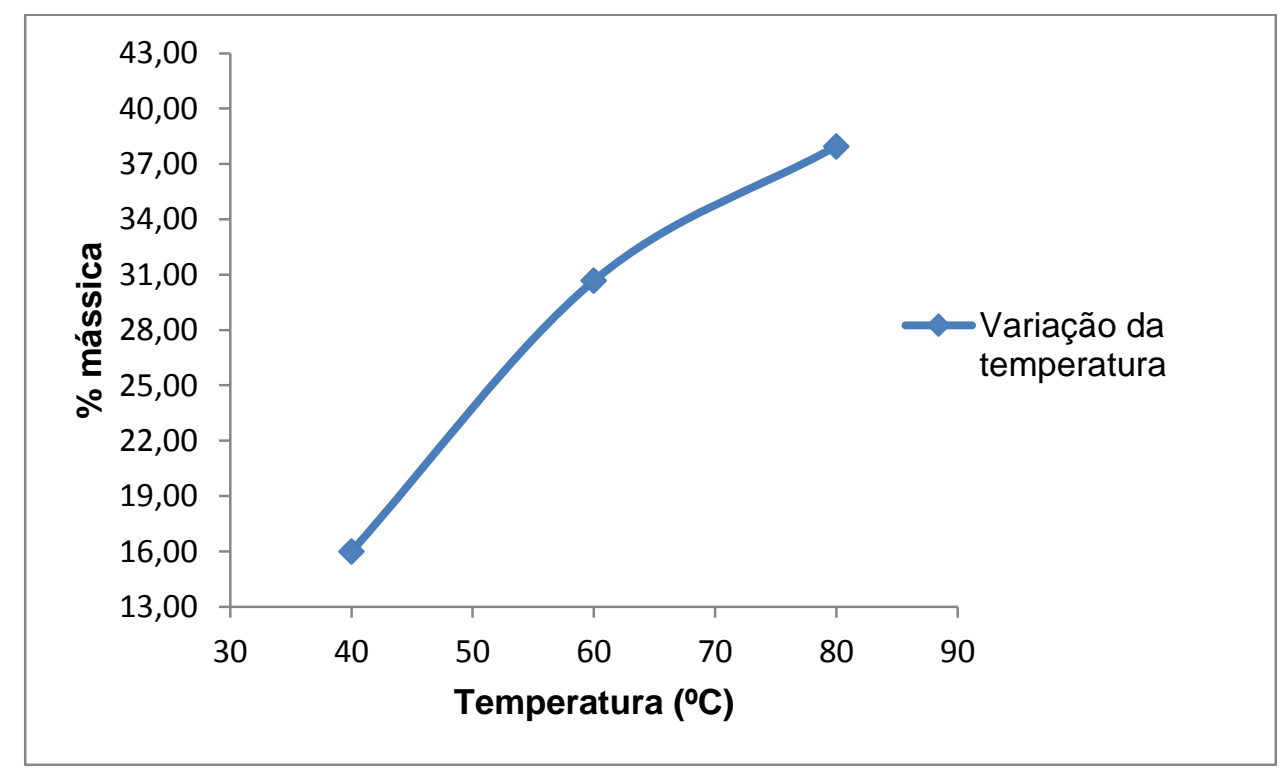

Figura 29 - Eficiência do processo de remoção de cromo sem lixiviação em função da variação da temperatura. 
De acordo com os resultados apresentados na Tabela 9, percebe-se que a eficiência do processo aumenta com a elevação do tempo de reação até 60 minutos e praticamente se estabiliza a partir desse tempo. Embora esse resultado seja diferente do obtido no Processo 1, como pode ser observado na Figura 30, o mesmo está consistente com os observados por Kuchar et al. (2010), que conclui que o melhor custo/benefício foi adquirido no tempo 60 minutos.

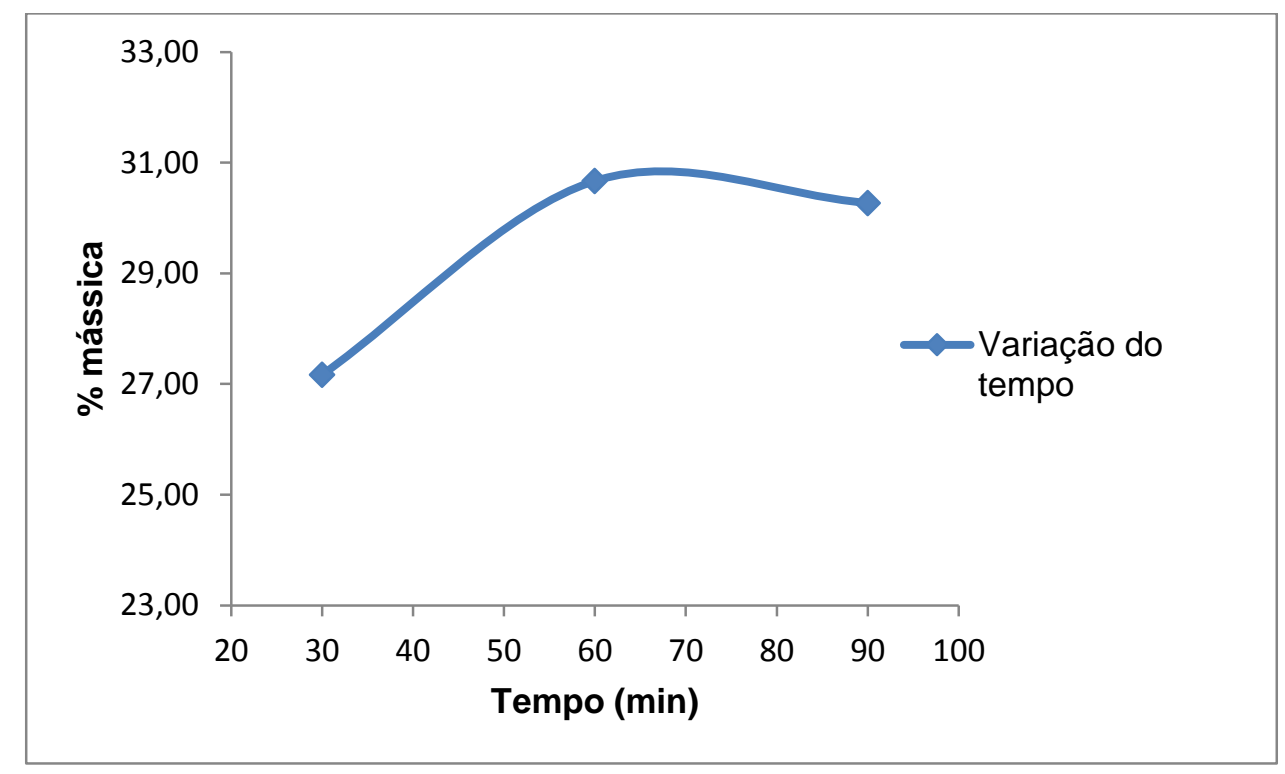

Figura 30 - Eficiência do processo de remoção de cromo sem lixiviação em função da variação do tempo de reação.

Em relação à variação da concentração de peróxido de hidrogênio, a eficiência do processo aumenta até $3,00 \mathrm{~mol}^{-\mathrm{L}^{-1}}$, sofrendo uma pequena queda de eficiência a partir desta concentração, conforme pode ser observado na Figura 31. Kuchar et al. (2010) e Silva et al. (2006) obtiveram resultados similares, isto é, o aumento da concentração de peróxido de hidrogênio resultou na elevação da eficiência do processo até atingir um equilíbrio, sendo que a partir deste a eficiência se manteve praticamente constante em relação ao aumento da concentração de $\mathrm{H}_{2} \mathrm{O}_{2}$. 


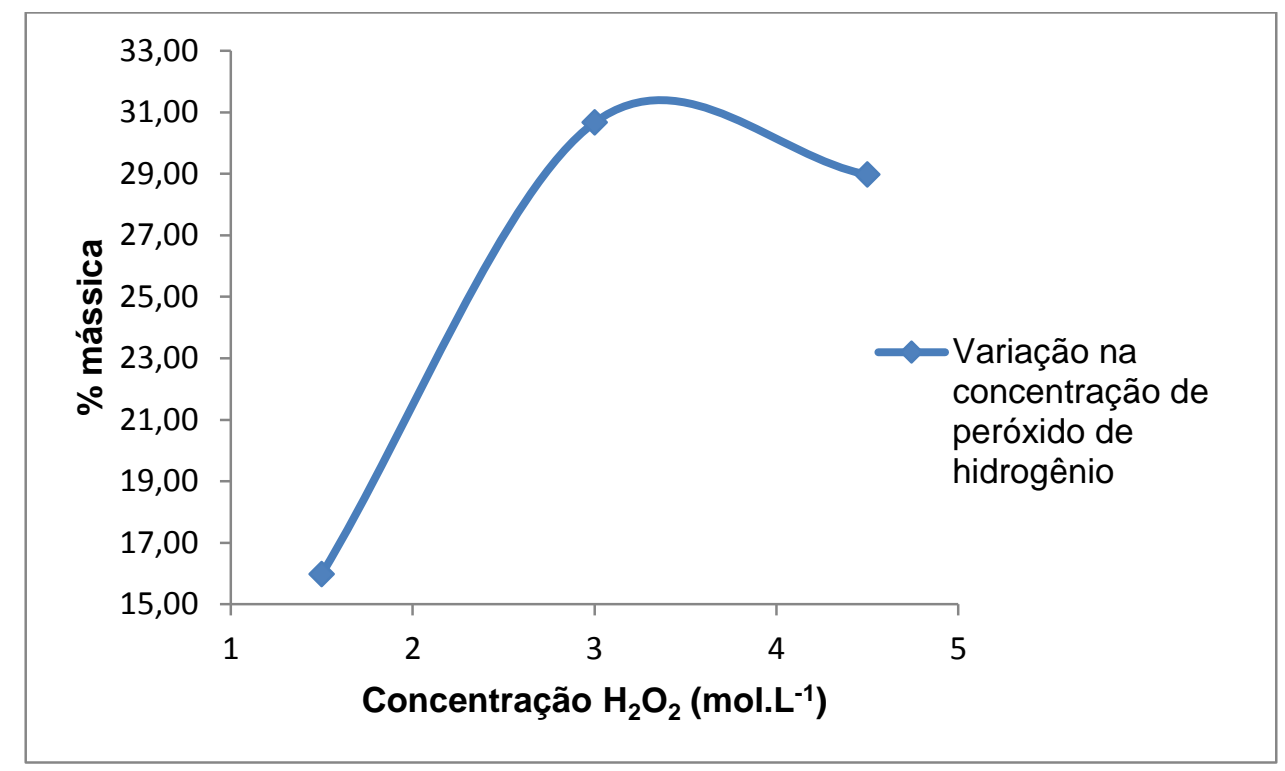

Figura 31 - Eficiência do processo de remoção de cromo sem lixiviação em função da variação da concentração de $\mathrm{H}_{2} \mathrm{O}_{2}$.

$\mathrm{Na}$ concentração de 1,50 mol.L-1 a eficiência do processo é menor 16,00\% em massa, inferior ao obtido no Processo 1 para as mesmas condições. No entanto, diferentemente do Processo 1, durante o processo de oxidação ocorreu a formação de uma espuma densa sobre a amostra, conforme pode ser observado na Figura 32. Como a amostra contém 10,28\% em massa de carbono, parte do $\mathrm{H}_{2} \mathrm{O}_{2}$ reage com este elemento, reduzindo assim a eficiência do processo. No processo 1 o carbono reage na lixiviação ácida, não interferindo na etapa de oxidação.

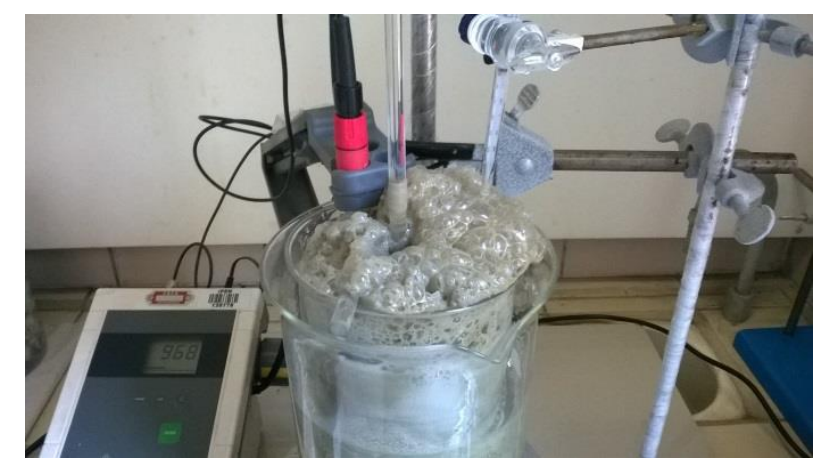

Figura 32 - Espuma densa formada sobre as amostras do Processo 2.

As frações precipitadas das sete amostras foram encaminhadas para as análises de FRX-EDX. Os resultados desta análise encontram-se no Apêndice $G$ e apresentados na Figura 33. Percebe-se que a composição mássica das 
amostras varia entre si, em função da heterogeneidade do lodo de galvanoplastia. Os resultados demonstram que a Amostra 3 , que obteve a maior eficiência de remoção, é a que contém menos cromo no precipitado. As Amostras 2 e 6 , que apresentaram a menor eficiência, possuem o maior teor de cromo no precipitado. Em relação ao cálcio, nota-se que a porcentagem mássica no precipitado é maior que a encontrada nas amostras do Processo 1 , em função de não haver a etapa de remoção do cálcio.

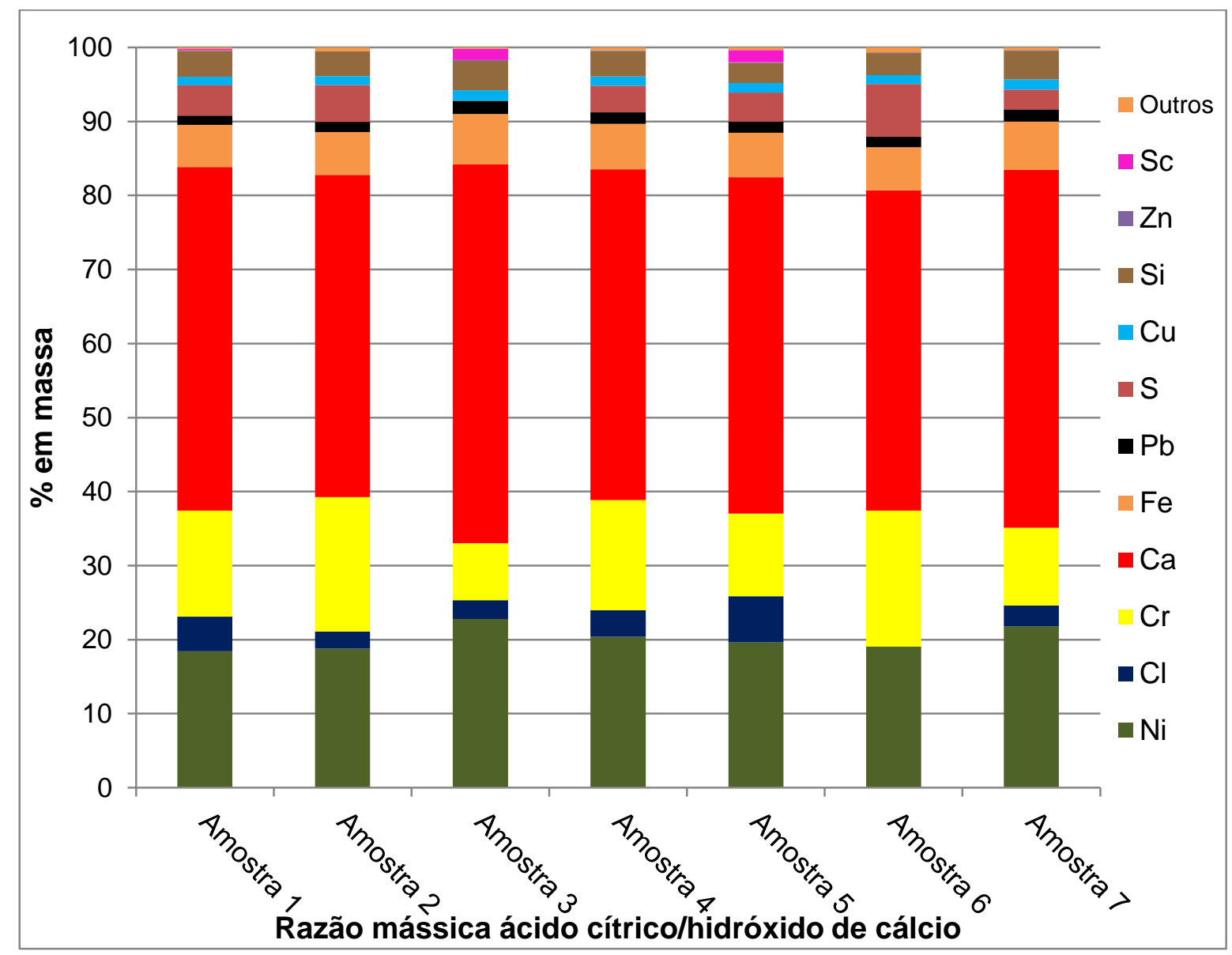

Figura 33 - Composição mássica do precipitado das sete amostras do Processo 2.

As amostras foram encaminhadas para a análise de ICP-OES, para se determinar a concentração de cromo nas frações precipitadas. Como realizado no Processo 1, utilizando resultados de ICP-OES e os valores das massas das amostras determinou-se a massa de cromo no precipitado, sendo o resultado apresentado na Tabela 10. A somatória da massa de cromo das amostras filtra- 
das e precipitadas totalizam 0,49 gramas de cromo, que corresponde a aproximadamente $60,00 \%$ do total inicial.

Tabela 11 - Balanço de massa de cromo na etapa de oxidação do Processo 2

\begin{tabular}{cccc}
$\begin{array}{c}\text { Massa de cromo na } \\
\text { amostra inicial }(\mathrm{g})\end{array}$ & $\begin{array}{c}\text { Massa de cromo no } \\
\text { filtrado }(\mathrm{g})\end{array}$ & $\begin{array}{c}\text { Massa de cromo no } \\
\text { precipitado }(\mathrm{g})\end{array}$ & $\begin{array}{c}\text { Perda } \\
(\mathrm{g})\end{array}$ \\
\hline 0,81 & 0,31 & 0,18 & 0,32
\end{tabular}

A lixiviação ácida não efetuou a sua solubilização total das amostras precipitadas, similar ao ocorrido no Processo 1. Então se supõem que parte da diferença quantificada entre a massa inicial de cromo e a massa determinada após a oxidação esteja presente no precipitado, mas que não foi possível determinar nas análises de ICP-OES.

O recipiente de alumina (cadinho) mudou de coloração após a realização da calcinação das amostras, conforme pode ser observado nas Figuras 34 e 35, indicado a reação da alumina com os elementos presentes no lodo de galvanoplastia. Acredita-se que, assim como ocorreu no Processo 1, uma fração do cromo reagiu com a alumina do cadinho durante a calcinação, resultando em perda no processo.

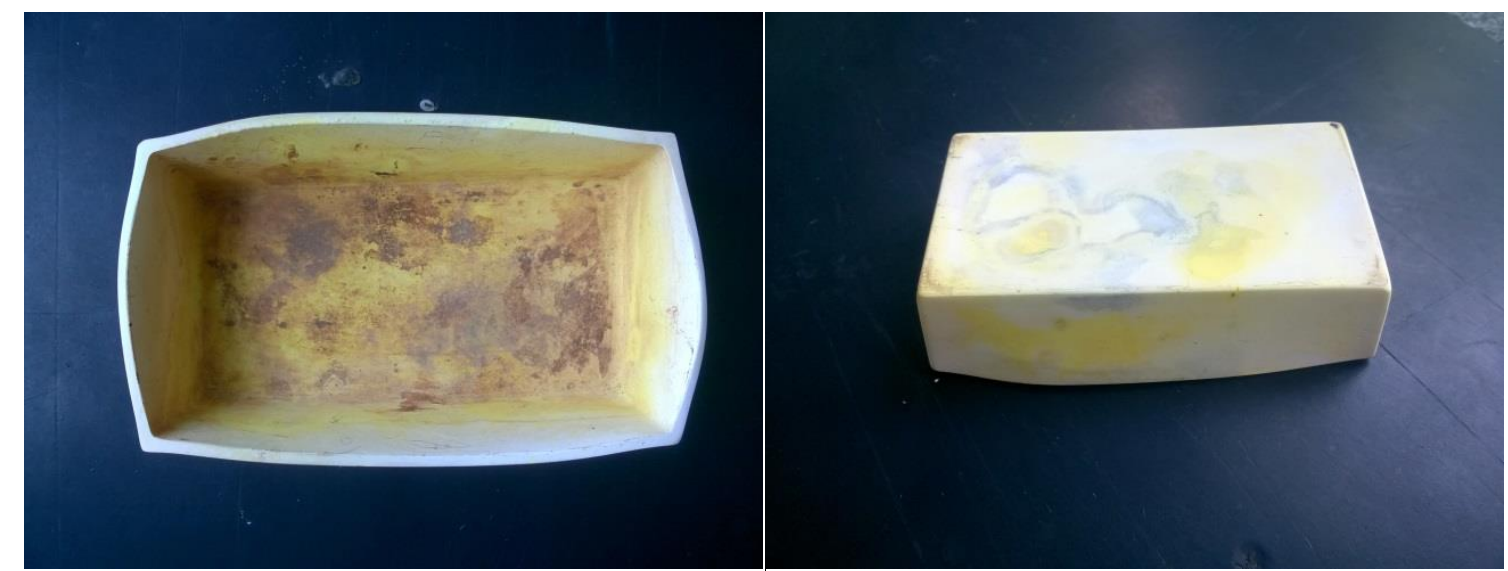

Figura 34 e 35- Cadinho de alumina após a calcinação das amostras precipitadas do Processo 2. 


\subsubsection{Comparação entre o processo 1 e o processo 2}

Segundo James et al. (2000), a presença de óxidos de cálcio no lodo de galvanoplastia pode reduzir a eficiência do processo de oxidação do cromo, devido à formação de cromatos de cálcio anidro insolúveis. Os resultados obtidos neste trabalho estão de acordo com o observado por estes autores, pois o Processo 1, onde realizou-se uma etapa para remoção do cálcio, obteve uma eficiência de remoção do cromo superior ao do Processo 2.

No entanto, os elevados custos para remoção do cálcio, apresentados na Tabela 4, demonstram que não é viável remover este elemento para aumentar a eficiência do processo de oxidação do cromo, visto que a eficiência do Processo 1 é aproximadamente 7,50\% em massa maior que a do Processo 2.

Para se obter uma comparação entre os dois processos, foram determinados os custos de recuperação do cromo utilizando apenas o valor médio de mercado dos reagentes empregados em cada processo, com base na cotação realizada em maio de 2015. O consumo de energia elétrica não pôde ser mensurado, por isso não foi considerado.

Utilizando os reagentes empregados nas etapas de cada processo, determinou-se o volume de cada reagente por grama de amostra. Isto é, calculouse para um grama de lodo galvânico a quantidade de ácido cítrico utilizado na etapa de remoção do cálcio, de água régia (ácido clorídrico e ácido nítrico na proporção de três para um) utilizada para lixiviação da amostra, de hidróxido de sódio para elevação do $\mathrm{pH}$ e de peróxido de hidrogênio utilizado na oxidação da amostra, para o Processo 1, e de hidróxido de sódio e peróxido de hidrogênio utilizado no Processo 2.

Com os volumes dos reagentes por grama de amostra e com os seus respectivos valores de marcado, foi determinado os custos dos dois processos, sendo estes apresentados na Tabela 11. Os custos do Processo 1 e 2 em dólar comercial são apresentados no Apêndice C. 
Tabela 12 - Custo dos processos de remoção do cromo por grama de lodo de galvanoplastia.

Reagentes Custos do Processo 1 (R\$) Custos do Processo 2 (R\$)

\begin{tabular}{ccc}
\hline Remoção do cálcio & 0,10 & - \\
\hline Água régia & 0,27 & - \\
\hline $\mathrm{NaOH}$ & 0,22 & 0,004 \\
\hline $\mathrm{H}_{2} \mathrm{O}_{2}$ & 0,09 & 0,09 \\
\hline Total & 0,68 & 0,094 \\
\hline
\end{tabular}

Os custos apresentados na Tabela 10 foram calculados utilizando como base um grama de lodo galvânico. No entanto, os dois processos executados visam à recuperação do cromo, que segundo a Tabela 2, representa 6,52\% em massa do lado galvânico. Portanto, para considerar os custos de recuperação de um grama de cromo foi utilizado o teor deste elemento no lodo e a maior eficiência obtida em cada processo de oxidação. Com base nas informações apresentadas, determinou-se que para recuperar um grama de cromo hexavalente o processo um obteve um custo total de $R \$ 25,09$ e o processo dois um valor de $R \$ 3,59$. Os resultados obtidos permitem afirmar que o Processo 2 possui meIhor viabilidade, pois o apresenta uma eficiência similar ao do processo um com custo, aproximadamente, seis vezes menor.

A empresa fornecedora do lodo de galvanoplastia informou que o ácido crômico utilizado no banho de cromação é obtido a um valor médio de $R \$ 21,00$ por quilograma. Portanto, se percebe que embora seja possível realizar a recuperação do cromo, os custos envolvidos em ambos os processos de recuperação inviabilizam economicamente a sua realização em escala industrial, mediante o preço de mercado do ácido crômico utilizado nas galvanoplastias. 


\section{CONCLUSÃo}

Com base nos resultados obtidos, concluiu-se que tanto no Processo 1 quanto no 2 foi possível remover o cromo presente no lodo da estação de tratamento de efluentes da empresa de galvanoplastia, conforme apresentado a seguir:

1. No processo de remoção do cálcio obteve-se uma eficiência maior que $50,00 \%$ em massa na razão mássica ácido cítrico/hidróxido de cálcio de 8,00 . No entanto, os custos envolvidos inviabilizam economicamente a sua aplicação comercial;

2. O material extraído no processo de remoção do cálcio foi considerado não perigoso, pois o teste de lixiviação realizado apresentou uma concentração de cromo inferior ao limite do Anexo F da ABNT NBR 10.004/04.

3. Entre as soluções utilizadas para lixiviação ácida das amostras, a água régia foi a que apresentou a maior eficiência.

4. O Processo 1 apresentou a maior eficiência de recuperação de cromo ( $41,09 \%$ em massa) utilizando a temperatura de $60^{\circ} \mathrm{C}$, concentração molar de $\mathrm{H}_{2} \mathrm{O}_{2}$ de $3,00 \mathrm{~mol} / \mathrm{L}$ e tempo de 30 minutos;

5. O Processo 2 obteve a eficiência de $37,96 \%$ em massa utilizando a temperatura de $80^{\circ} \mathrm{C}$, concentração molar de $\mathrm{H}_{2} \mathrm{O}_{2}$ de $3,00 \mathrm{~mol} / \mathrm{L}$ e tempo de 60 minutos;

6. Os custos de remoção do cromo no Processo 2 são inferiores aos obtidos no Processo 1. Porém, os dois processos não apresentaram viabilidade econômica para aplicação em escala industrial;

7. A remoção do cromo do lodo de galvanoplastia representa ganhos ambientais, pela diminuição deste elemento no resíduo de galvanoplastia, que na maioria das vezes é disposto em aterros classe I, gerando um passivo ambiental. 
APÊNICE A - Tabela contendo a composição mássica do lodo de galvanoplastia realizada por FRX-EDX.

\begin{tabular}{cc}
\hline Elemento & Porcentagem mássica (\%) \\
\hline $\mathrm{Ca}$ & 42,44 \\
\hline $\mathrm{Cr}$ & 20,41 \\
\hline $\mathrm{Ni}$ & 13,43 \\
\hline $\mathrm{S}$ & 13,29 \\
\hline $\mathrm{Fe}$ & 4,19 \\
\hline $\mathrm{Si}$ & 2,00 \\
\hline $\mathrm{P}$ & 1,09 \\
\hline $\mathrm{Ba}$ & 1,03 \\
\hline $\mathrm{Pb}$ & 0,97 \\
\hline $\mathrm{Cu}$ & 0,84 \\
\hline $\mathrm{K}$ & 0,14 \\
\hline $\mathrm{Sr}$ & 0,10 \\
\hline $\mathrm{Zn}$ & 0,07 \\
\hline
\end{tabular}


APÊNDICE B - Tabela contendo a composição mássica do filtrado na etapa de remoção do cálcio no Processo 1.

\begin{tabular}{cccc}
\hline Elemento & Razão 2,5 (\%) & Razão 5,5 (\%) & Razão 8,0 (\%) \\
\hline $\mathrm{Ni}$ & 29,88 & 28,44 & 28,3 \\
\hline $\mathrm{Ca}$ & 27,23 & 24,73 & 22,23 \\
\hline $\mathrm{Cr}$ & 24,15 & 26,29 & 27,50 \\
\hline $\mathrm{Fe}$ & 7,01 & 7,59 & 7,71 \\
\hline $\mathrm{S}$ & 5,21 & 5,66 & 6,23 \\
\hline $\mathrm{Pb}$ & 2,42 & 1,86 & 1,90 \\
\hline $\mathrm{Cu}$ & 2,07 & 2,24 & 2,56 \\
\hline $\mathrm{Si}$ & 1,29 & 3,19 & 2,62 \\
\hline $\mathrm{Zn}$ & 0,74 & - & 0,76 \\
\hline
\end{tabular}




\section{APÊNDICE C - Custos dos processos de remoção do cromo em dólar comercial, cotado dia 20/05/2015.}

Tabela 13 - Custo em dólar da extração do cálcio baseado na massa de ácido cítrico.

\begin{tabular}{ccccc}
\hline Análises & $\begin{array}{c}\text { Eficiência } \\
(\%)\end{array}$ & $\begin{array}{c}\text { Massa Ca ex- } \\
\text { traída }(\mathbf{g})\end{array}$ & $\begin{array}{c}\text { Custo ácido cí- } \\
\text { trico (US\$) }\end{array}$ & $\begin{array}{c}\text { Custo por gra- } \\
\text { ma (US\$) }\end{array}$ \\
\hline $\begin{array}{c}\text { Razão } \\
2,5\end{array}$ & 24,83 & 1,19 & 0,28 & 0,24 \\
\hline $\begin{array}{c}\text { Razão } \\
5,5\end{array}$ & 36,75 & 1,76 & 0,58 & 0,33 \\
\hline $\begin{array}{c}\text { Razão } \\
8,0\end{array}$ & 51,76 & 2,49 & 0,84 & 0,34 \\
\hline
\end{tabular}

1 Dólar comercial (US\$) = 3,003 Reais brasileiro (R\$) em 20/05/2015

Tabela 14- Custos em dólar da lixiviação ácida por grama de lodo de galvanoplastia, considerando os três agentes extratores.

\begin{tabular}{cc}
\hline Agente Extrator & Custo da lixiviação por grama de lodo (US\$) \\
\hline Água régia & 0,09 \\
\hline Água régia invertida & 0,12 \\
\hline Ácido clorídrico & 0,07 \\
\hline \multicolumn{2}{c}{ 1 Dólar comercial (US\$) =3,003 Reais brasileiro (R\$) em 20/05/2015 }
\end{tabular}

Tabela 15 - Custo em dólar dos processos de remoção do cromo por grama de lodo de galvanoplastia.

\begin{tabular}{ccc}
\hline Reagentes & Custos do Processo 1 (US\$) & Custos do Processo 2 (US\$) \\
\hline $\begin{array}{c}\text { Remoção do } \\
\text { cálcio }\end{array}$ & 0,03 & - \\
\hline Água régia & 0,09 & - \\
\hline $\mathrm{NaOH}$ & 0,07 & 0,001 \\
\hline $\mathrm{H}_{2} \mathrm{O}_{2}$ & 0,03 & 0,030 \\
\hline Total & 0,23 & 0,031
\end{tabular}

1 Dólar comercial (US $\$$ ) = 3,003 Reais brasileiro (R\$) em 20/05/2015 
APÊNDICE D - Tabela contendo a composição mássica do precipitado da etapa de remoção do cálcio no Processo 1.

\begin{tabular}{cccc}
\hline Elemento Razão 2,5 (\%) & Razão 5,5 (\%) & Razão 8,0 (\%) \\
\hline $\mathrm{Ca}$ & 54,45 & 52,29 & 49,95 \\
\hline $\mathrm{S}$ & 29,73 & 38,12 & 36,14 \\
\hline $\mathrm{P}$ & 2,06 & 3,12 & 4,46 \\
\hline $\mathrm{Si}$ & 2,01 & 3,59 & 3,29 \\
\hline $\mathrm{Cr}$ & 5,87 & 0,72 & 1,89 \\
\hline $\mathrm{Fe}$ & 1,92 & 0,84 & 1,59 \\
\hline $\mathrm{Ba}$ & 1,32 & 0,70 & 1,07 \\
\hline $\mathrm{Ni}$ & 1,30 & 0,34 & 0,87 \\
\hline $\mathrm{K}$ & 0,46 & - & 0,28 \\
\hline $\mathrm{Pb}$ & 0,55 & 0,13 & 0,20 \\
\hline $\mathrm{Sr}$ & 0,14 & 0,06 & 0,10 \\
\hline $\mathrm{Cu}$ & 0,14 & 0,05 & 0,10 \\
\hline $\mathrm{Zn}$ & 0,05 & 0,05 & 0,06 \\
\hline
\end{tabular}


APÊNDICE E - Tabela contendo a composição mássica do precipitado das três lixiviações ácidas.

\begin{tabular}{cccc}
\hline Elemento Água régia (\%) & Água régia invertida (\%) & Ácido clorídrico (\%) \\
\hline $\mathrm{Si}$ & 43,75 & 46,06 & 37,77 \\
\hline $\mathrm{Ca}$ & 20,26 & 20,16 & 12,32 \\
\hline $\mathrm{Cr}$ & 9,16 & 8,78 & 28,65 \\
\hline $\mathrm{S}$ & 8,56 & 8,04 & 5,40 \\
\hline $\mathrm{Ni}$ & 6,76 & 6,27 & 4,41 \\
\hline $\mathrm{Ba}$ & 5,63 & 4,45 & 4,21 \\
\hline $\mathrm{Fe}$ & 2,61 & 3,04 & 4,53 \\
\hline $\mathrm{Al}$ & 1,69 & 1,81 & 1,43 \\
\hline $\mathrm{K}$ & 0,48 & 0,51 & 0,35 \\
\hline $\mathrm{Cu}$ & 0,43 & 0,40 & 0,43 \\
\hline $\mathrm{Pb}$ & 0,35 & 0,33 & 0,29 \\
\hline $\mathrm{Sr}$ & 0,23 & 0,15 & 0,11 \\
\hline $\mathrm{Zn}$ & 0,10 & - & 0,10 \\
\hline
\end{tabular}


APÊNDICE F - Tabela contendo a composição mássica do precipitado das oito amostras do Processo 1, realizada por FRX-EDX.

\begin{tabular}{ccccccccc}
\hline $\begin{array}{c}\text { Ele- } \\
\text { mento }\end{array}$ & $\begin{array}{c}\text { Amos- } \\
\text { tra 1 }\end{array}$ & $\begin{array}{c}\text { Amos- } \\
\text { tra 2 }\end{array}$ & $\begin{array}{c}\text { Amos- } \\
\text { tra 3 }\end{array}$ & $\begin{array}{c}\text { Amos- } \\
\text { tra 4 }\end{array}$ & $\begin{array}{c}\text { Amos- } \\
\text { tra 5 }\end{array}$ & $\begin{array}{c}\text { Amos- } \\
\text { tra 6 }\end{array}$ & $\begin{array}{c}\text { Amos- } \\
\text { tra 7 }\end{array}$ & $\begin{array}{c}\text { Amos- } \\
\text { tra 8 }\end{array}$ \\
\hline $\mathrm{Ni}$ & 19,33 & 18,47 & 21,52 & 17,72 & 14,34 & 29,33 & 30,41 & 32,92 \\
\hline $\mathrm{Cr}$ & 10,70 & 15,48 & 16,38 & 9,20 & 8,65 & 11,40 & 14,94 & 11,34 \\
\hline $\mathrm{Ca}$ & 11,68 & 14,31 & 12,56 & 17,24 & 14,08 & 14,14 & 13,11 & 13,61 \\
\hline $\mathrm{Fe}$ & 7,69 & 5,70 & 6,53 & 10,01 & 4,55 & 8,91 & 8,78 & 9,64 \\
\hline $\mathrm{P}$ & 2,88 & 0,88 & 2,75 & 2,96 & 1,80 & 3,64 & 2,77 & 2,46 \\
\hline $\mathrm{Pb}$ & 0,07 & 1,39 & 1,29 & 2,74 & 1,77 & 0,97 & 2,64 & 2,67 \\
\hline $\mathrm{S}$ & 6,64 & 1,78 & - & 3,13 & - & 1,51 & 1,92 & 1,89 \\
\hline $\mathrm{Cu}$ & 0,23 & 1,35 & 1,39 & 2,18 & 0,93 & 1,65 & 1,84 & 2,10 \\
\hline $\mathrm{Zn}$ & 0,03 & 0,11 & 0,11 & 0,18 & 0,08 & 0,19 & 0,20 & 0,17 \\
\hline $\mathrm{Sr}$ & 0,21 & 0,02 & - & - & 0,02 & 0,02 & - & - \\
\hline $\mathrm{Cl}$ & 40,60 & 40,29 & 37,33 & 33,95 & 53,66 & 27,49 & 23,38 & 22,45 \\
\hline $\mathrm{Sn}$ & - & 0,13 & 0,15 & 0,21 & 0,11 & 0,19 & - & 0,17 \\
\hline $\mathrm{Mn}$ & - & - & - & 0,49 & - & 0,51 & - & 0,56 \\
\hline
\end{tabular}


APÊNDICE G - Tabela contendo a composição mássica do precipitado das sete amostras do Processo 2, realizada por FRX-EDX.

\begin{tabular}{ccccccccc}
\hline Ele- & Amostra & Amostra & Amostra & Amostra & Amostra & Amostra & Amostra \\
mento & $\mathbf{1}$ & $\mathbf{2}$ & $\mathbf{3}$ & $\mathbf{4}$ & $\mathbf{5}$ & $\mathbf{6}$ & $\mathbf{7}$ \\
\hline $\mathrm{Ni}$ & 18,45 & $\mathbf{1 8 , 7 7}$ & 22,77 & 20,40 & 19,64 & 19,04 & 21,83 \\
\hline $\mathrm{Cl}$ & 4,67 & 2,33 & 2,54 & 3,61 & 6,22 & & 2,79 \\
\hline $\mathrm{Cr}$ & 14,31 & 18,16 & 7,74 & 14,84 & 11,18 & 18,39 & 10,49 \\
\hline $\mathrm{Ca}$ & 46,43 & 43,54 & 51,17 & 44,70 & 45,42 & 43,28 & 48,38 \\
\hline $\mathrm{Fe}$ & 5,69 & 5,76 & 6,79 & 6,12 & 6,04 & 5,79 & 6,51 \\
\hline $\mathrm{Pb}$ & 1,25 & 1,40 & 1,77 & 1,56 & 1,48 & 1,45 & 1,62 \\
\hline $\mathrm{S}$ & 4,07 & 4,98 & & 3,62 & 3,94 & 7,12 & 2,67 \\
\hline $\mathrm{Cu}$ & 1,16 & 1,20 & 1,44 & 1,23 & 1,27 & 1,20 & 1,38 \\
\hline $\mathrm{Si}$ & 3,46 & 3,37 & 3,97 & 3,41 & 2,71 & 2,96 & 3,87 \\
\hline $\mathrm{Zn}$ & 0,13 & - & 0,13 & 0,11 & 0,11 & 0,11 & 0,12 \\
\hline $\mathrm{Sc}$ & 0,15 & & 1,50 & - & 1,62 & - & - \\
\hline $\mathrm{Sn}$ & 0,09 & 0,10 & - & & - & - & - \\
\hline $\mathrm{Sr}$ & 0,13 & 0,13 & 0,17 & 0,14 & - & 0,14 & 0,16 \\
\hline $\mathrm{Ba}$ & - & - & - & - & - & 0,39 & - \\
\hline $\mathrm{Ti}$ & - & 0,14 & - & 0,16 & - & - & 0,18 \\
\hline $\mathrm{Os}$ & - & 0,13 & - & 0,09 & 0,13 & 0,09 & - \\
\hline & & & & & & & \\
\hline
\end{tabular}




\section{REFERÊNCIAS BIBLIOGRÁFICAS}

AGENCY FOR TOXIC SUBSTANCES AND DISEASE REGISTRY. Chromium. Atlanta, 2008. Disponível em: http://www.atsdr.cdc.gov/toxfags/tf.asp?id=61\&tid $\equiv 17$. Acesso em 06 de Agosto de 2015.

AMERICAN PUBLIC HEALTH ASSOCIATION. Standard methods for the examination of water and wastewater. 20 ed. Washington: APHA, 1998. 937 p.

ASSOCIAÇÃO BRASILEIRA DE NORMAS TÉCNICAS. Aterros de resíduos perigosos - Critérios para projeto, construção e operação. NBR 10.157. Rio de Janeiro: ABNT, 1987.

ASSOCIAÇÃO BRASILEIRA DE NORMAS TÉCNICAS. Armazenamento de resíduos sólidos perigosos. NBR 12.235. Rio de Janeiro: ABNT, 1992.

ASSOCIAÇÃO BRASILEIRA DE NORMAS TÉCNICAS. Resíduos sólidos Classificação. NBR 10.004. Rio de Janeiro: ABNT, 2004.

ASSOCIAÇÃO BRASILEIRA DE NORMAS TÉCNICAS. Procedimento para obtenção de extrato lixiviado de resíduos sólidos. NBR 10.005. Rio de Janeiro: ABNT, 2004.

ASSOCIAÇÃO BRASILEIRA DE NORMAS TÉCNICAS. Amostragem de resíduos sólidos. NBR 10.007. Rio de Janeiro: ABNT, 2004.

BRAILE, P.M.; CAVALCANTI, J.E.W.A. Manual de tratamento de águas residuárias. São Paulo: CETESB, 1993. 764 p.

COMPANHIA AMBIENTAL DO ESTADO DE SÃO PAULO (CETESB). Plano de resíduos sólidos do Estado de São Paulo. São Paulo: CETESB, 2014.

COMPANHIA AMBIENTAL DO ESTADO DE SÃO PAULO (CETESB). Bijuterias: Série P+L. São Paulo: CETESB, 2005. 
COMPANHIA AMBIENTAL DO ESTADO DE SÃO PAULO (CETESB). Relatório de estabelecimento de valores orientadores para solos e águas subterrâneas. São Paulo. CETESB, 2001.

COMPANHIA AMBIENTAL DO ESTADO DE SÃO PAULO (CETESB). Inventário de resíduos industriais. São Paulo: CETESB, 1996. Disponível em: http://resi duossolidos.cetesb.sp.gov.br/residuos-solidos/residuos-industriais/introducaoresiduos-industriais/. Acesso em 22 de junho de 2015.

COMPANHIA PERNAMBUCANA DO MEIO AMBIENTE. Roteiro complementar de licenciamento e fiscalização: tipologia galvanoplastia. Recife: $\mathrm{CPRH}$, 2001. $107 \mathrm{p}$.

FÖLDES, P.A. Galvanotécnica prática. São Paulo: Polígono, Universidade de São Paulo, 1973. 355 p.

INSTITUTO BRASILEIRO DE ADMINISTRAÇÃO MUNICIPAL. Manual de gerenciamento integrado de resíduos sólidos. Rio de Janeiro: IBAM, 2001. $200 \mathrm{p}$.

JAMES, M.G.; BEATTIE, J.K.; KENNEDY, BRENDAN J. Recovery of chromate from electroplating sludge. Was. Man. \& Res. p. 380-385,2000.

KUCHAR, D.; FUKUTA, T.; KUBOTA, M.; MATSUDA, H. Recovery of Cu, Zn, Ni and $\mathrm{Cr}$ from Plating Sludge by Combined Sulfidation and Oxidation Treatment. Int. J. of Civ. and Env. Eng. p. 62-66.2010.

KURNIAWAN, T.A.; CHAN, G.Y.S.; LOA, W.; Babel, S. Physico-chemical treatment techniques for wastewater laden with heavy metals. Chem. Eng. J. p. 83-98. 31 jan. 2006. 
MAGALHÃES, J.M.; SILVA, J.E.; CASTRO, F.P.; LABRINCHA, J.A. Effect of experimental variables on the inertization of galvanic sludges in clay-based ceramics. J. of Env. Man., v. 106B, p. 139-147, 2004.

MAGALHÃES, J.M.; SILVA, J.E.; CASTRO, F.P.; LABRINCHA, J.A. Physical and chemical characterization of metal finishing industrial wastes. J. of Env. Manag. v. 75, p. 157-166. 2005.

MALAGONI, R. A.; JÚNIOR, A. C. G. S.; FINZER, J. R. D. Produção de citrato de cálcio a partir do ácido cítrico presente no suco do limão Tahiti. Engenharia de Alimentos/food Engineering, Uberaba, v. 6, p.53-82, 2009.

MANSUR, M.B.; ROCHA, S.D..F; MAGALHÃES, F.S.; BENEDETTO, J.S. Selective extraction of zinc(II) over iron(II) from spent hydrochloric acid pickling effluents by liquid-liquid extraction. Hazard. Mat. p. 669-678. 08 mai 2008.

MARDER, L.; SULZBACH, G.O.; BERNARDES, A.M.; FERREIRA, J.Z. Removal of cadmium and cyanide from aqueous solutions through electrodialysis. J. Bra. Chem. Soc. v.14, ㄲo 4, 2003.

MATTOS, C.S. Geração de resíduos sólidos de galvanoplastia em regiões densamente povoadas - avaliação, inertização e destinação. 2011. 134 f. Dissertação (Mestrado) - Instituto De Pesquisas Energéticas e Nucleares, São Paulo, 2011.

MEYERS, R.A. Inductively Coupled Plasma/Optical Emission Spectrometry. John Wiley \& Sons Ltd, 2000.

MILANEZ, K.W.; KNIESS, C.T.; BERNARDIN, A.M.; RIELLA, H.G.; KUHNEN, N.C. Caracterização de pigmentos inorgânicos à base de $\mathrm{Fe}, \mathrm{Zn}$, e $\mathrm{Cr}$ utilizando resíduo de galvanoplastia como matéria-prima. Cerâmica, v. 51, n. 318, p. 107-110, 2005. 
MOURA, S.C.; COELHO, F.; BUSTILLOS, J.O.W.V. Characterization of Carbon, Sulfur and Volatile Compounds in nuclear fuel (U3Si2-AI). In: 2013 International Nuclear Atlantic Conference, 2013, Recife. 2013 International Nuclear Atlantic Conference. Recife: 2013 International Nuclear Atlantic Conference, 2013. v. 1. p. 1-2.

NETO, A.P.; BRETZ, J.S.; MAGALHÃES, F.S.; MANSUR, M.B.; ROCHA, S.D.F. Alternativas para o tratamento de efluentes da indústria galvânica. Eng. San. e Amb., São Paulo, v. 13, n. 3, p.263-270. 21 mar 2008.

RACT, P.G.; ESPINOSA, D.C.R.; TENÓRIO, J.A.S. Determination of $\mathrm{Cu}$ and Ni incorporation ratios in Portland cement clinker. Waste Man. p. 281-285, 2003.

PACHECO, C.E.M. Compilação de técnicas de prevenção à poluição para a indústria de galvanoplastia: projeto piloto de prevenção à poluição em indústrias de bijuterias no município de Limeira. 4a ed., São Paulo: CETESB, 2002.

PONTE, H.A. Tratamento de efluentes líquidos de galvanoplastia. Disciplina de Eletroquímica, Curso de Engenharia Química, Universidade Federal do Paraná. Curitiba, 2002.

PRADO, T.C.; MOURA, S.C.; SASSINE, A.; LÉO, V.M.; BUSTILLOS, J.O.V. Metrologia aplicada nas análises de carbono e enxofre em aços de interesse nuclear. In: III Congresso Latino Americano de Metrologia. Curitiba, 2002.

RAMANATHAN, L.V. Corrosão e seu controle. São Paulo: Hemus, 1990. 341 p.

ROCCA, A.C.C. et al. Resíduos sólidos industriais. 2.ed. São Paulo. CETESB, 234p. 1993. 
ROSSINI, G.; BERNARDES, A.M.; Galvanic sludge metals recovery by pyrometallurgical and hydrometallurgical treatment. J. of Haz. Mat. 131, 210216. 17 abr 2006.

SCHNEIDER V.E.; BETTIN, F.; JUNIOR, F.P. Situação das indústrias galvânicas na região nordeste do estado do rio grande do sul quanto ao passivo ambiental de lodos de estações de tratamento de efluentes. In: XXVII CONGRESSO INTERAMERICANO DE ENGENHARIA SANITÁRIA E AMBIENTAL, 2000, Porto Alegre - RS. Anais do XXVII Congresso Interamericano de Engenharia Sanitária e Ambiental. Rio de Janeiro: ABES, 2000.

SERVIÇO DE APOIO ÀS MICRO E PEQUENAS EMPRESAS NO ESTADO DO RIO DE JANEIRO. Manual de gerenciamento de resíduos. Rio de Janeiro: Gma, 2006. 27 p.

SENAI. Serviço Nacional de Indústria. Manual de orientações técnicas básicas para a minimização de efluentes e resíduos na indústria galvânica. Porto Alegre: Senai-RS, 2002.

SESI. Serviço Social da Indústria. Manual de segurança e saúde no trabalho indústria galvânica. São Paulo: Coleção Manuais, 2007.

SILVA, A.C.; MELLO-CASTANHO, S.R.H. Silicate glasses obtained from fine silica powder modified with galvanic waste addition. J. Non-Cry. Sol. v. 348, p. 211-217, 2004.

SILVA, P.T.S.; MELLO, N.T.; DUARTE, M.M.M.; MONTENEGRO, M.C.B.S.M.; ARAÚJO, A.N.; NETO, B.B.; SILVA, V.L. Extraction and recovery of chromium from electroplating sludge. J. of Haz. Mat. B128, 39-44, 06 set 2006.

SIMAS, R. Levantamento da geração de resíduos galvânicos e minimização de efluentes contendo cianeto. 2007. 148 f. Dissertação (Mestrado) Universidade Federal do Paraná, Curitiba, 2007. 
SKOOG, D. A.; HOLLER, F. J; NIEMAN, T. A. Princípios de análise instrumental. 5. ed., Porto Alegre: Bookman, 2002, 836 p.

SOARES, L.C. Estudo da retenção de cromo em alumina, gibbsita e aluminossilicatos e avaliação dos processos de lixiviação. $91 \mathrm{f}$. Dissertação (Mestrado) - Curso de Química - Química Inorgânica. Universidade Federal de Minas Gerais, Belo Horizonte, 2010.

TOCCHETTO, M.R.L. Implementação de gestão ambiental de grandes empresas com atividade galvânica no Rio Grande do Sul. 2004. 162 f. Tese (Doutorado) - Universidade Federal do Rio Grande do Sul, Porto Alegre, 2004.

Valenzuela, J. Tratamento de efluentes em indústrias galvanotécnicas. 2a ed. São Paulo: Páginas \& Letras, 2008. 126p.

VALLE, C.E. Qualidade ambiental: 0 desafio de ser competitivo protegendo o meio ambiente. São Paulo: Pioneira, 1995. 117p.

VEGLIÒ, F.; QUARESIMA, R.; FORNARI, P.; UBALDINI, S. Recovery of valuable metals from electronic and galvanic industrial wastes by leaching and electrowinning. Waste Management, v. 23. p. 245-252. 2003.

WORLD HEALTH ORGANIZATION. International Programme on Chemical Safety: Environmental Health Criteria 61 - Chromium. Geneva, 1988. Disponível em: http://www.inchem.org/documents/ehc/ehc/ehc61.htm. Acesso em 16 de julho de 2015. 